\title{
Composition and Property Measurements for PHA Phase 4 Glasses
}

by

T. B. Edwards

Westinghouse Savannah River Company

Savannah River Site

Aiken, South Carolina 29808

J. R. Harbour

R. J. 'Workman

This paper was prepared in connection with work done under the above contract number with the U.S. Department of Energy. By acceptance of this paper, the publisher and/or recipient acknowledges the U.S. Government's right to retain a nonexclusive, royalty-free license in and to any copyright covering this paper, along with the right to reproduce and to authorize others to reproduce all or part of the copyrighted paper. 
Keywords: Coupled Operations, DWPF, PCT, PCCS, Liquidus Temperature, Salt Disposition, Viscosity

Retention Time: Permanent

\section{COMPOSITION AND PROPERTY MEASUREMENTS FOR PHA Phase 4 Glasses (U)}

T. B. Edwards

J. R. Harbour

R. J. Workman

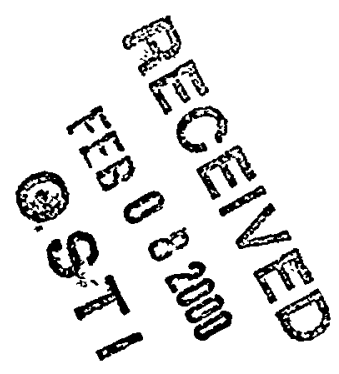

Westinghouse Savannah River Company

Savannah River Technology Center Aiken, SC 29808

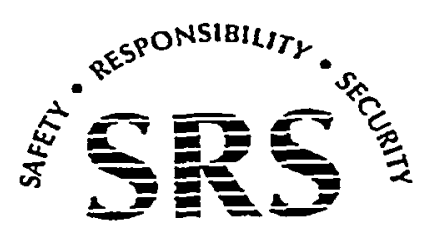

SAVANNAH RIVER SITE

PREPARED FOR THE U.S. DEPARTMENT OF ENERGY UNDER CONTRACT NO. DE-AC09-96SR18500 
WSRC-TR-99-00294

Revision 0

\section{DISCLAIMER}

This report was prepared as an account of work sponsored by an agency of the United States Government. Neither the United States Government nor any agency thereof, nor any of their employees, makes any warranty, express or implied, or assumes any legal liability or responsibility for the accuracy, completeness, or usefulness of any information, apparatus, product, or process disclosed, or represents that its use would not infringe privately owned rights. Reference herein to any specific commercial product, process, or service by trade name, trademark, manufacturer, or otherwise does not necessarily constitute or imply its endorsement, recommendation, or favoring by the United States Government or any agency thereof. The views and opinions of authors expressed herein do not necessarily state or reflect those of the United States Government or any agency thereof.

This report has been reproduced directly from the best available copy.

Available to DOE and DOE contractors from the Office of Scientific and Technical Information, P.O. Box 62, Oak Ridge, TN 37831; prices available from (615) 576-8401.

Available to the public from the National Technical Information Service, U.S. Department of Commerce, 5285 Port Royal Road, Springfield, VA 22161. 


\section{DISCLAIMER}

Portions of this document may be illegible in electronic image products. Images are produced from the best available original document. 
WSRC-TR-99-00294

Revision 0

Composition and Property Measurements FOR PHA PHASE 4 GLASSES (U)

$=$

August 18, 1999

Document Approvals

Thomas \& Edwards

T. B. Edwards, Author Statistical Consulting Section

G hm N Harlow

J. R. Hafpour, Author Immobilization Technology Section

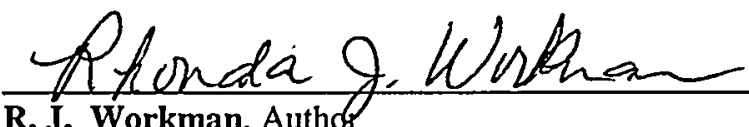

Immobilization Technology Section

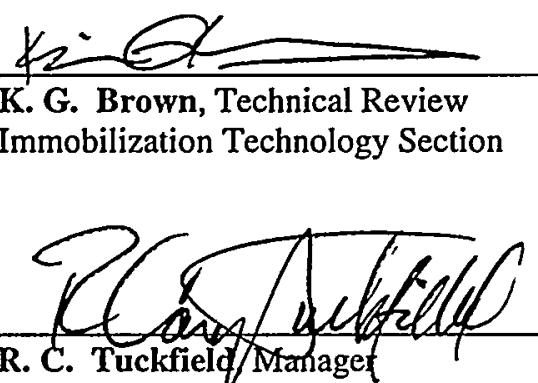

Statistical Consulting Section

EN Haetzacheate

E. W. Holtzscheiter, Manager, Immobilization Technology Section Authorized Derivative Classifier
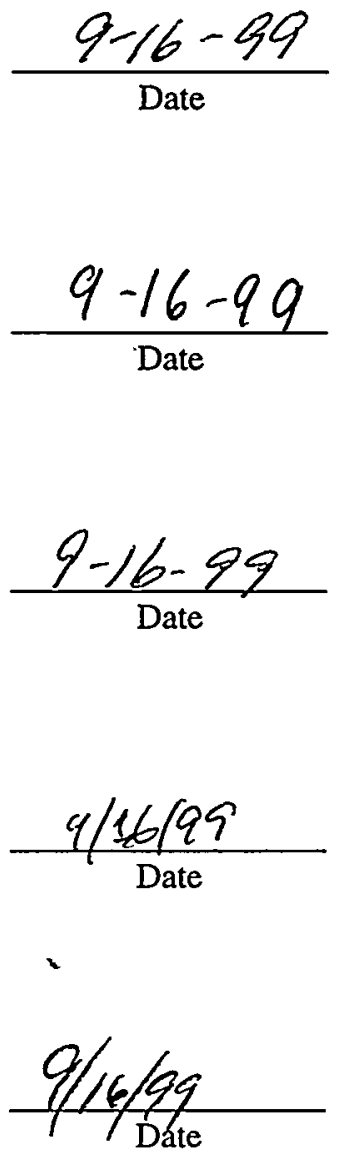

$\frac{9-16-99}{\text { Date }}$

iii 
WSRC-TR-99-00294

Revision 0

$\because$

This page intentionally left blank. 


\section{TABLE OF CONTENTS}

Summary and Conclusions ................................................ 1

Introduction ............................................................ 1

Results and Discussion ................................................ 2

Chemical Compositions ............................................. 2

PCT Results ....................................................... 7

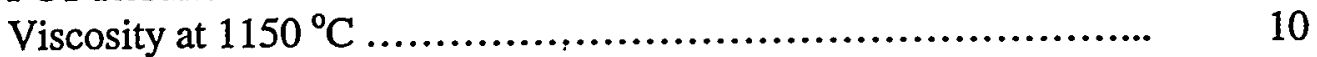

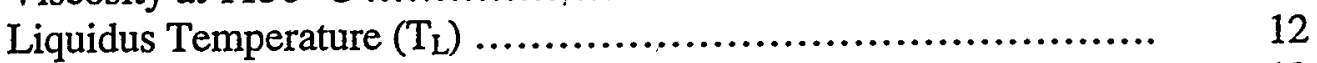

Surface Crystallization ............................................ 12

Phase Separation ................................................. 13

Conclusions ............................................................ 14

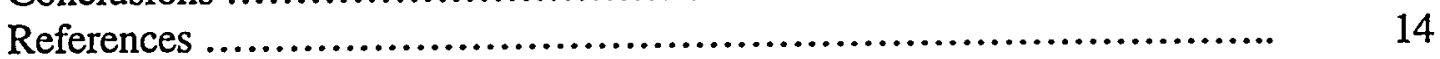

Appendix A: Supplemental Tables and Exhibits ........................... 17

Appendix $\overline{\mathrm{B}}$ : Two Additional Glasses .................................... 61 
WSRC-TR-99-00294

Revision 0

This page intentionally left blank. 


\section{SUMMARY AND CONCLUSIONS}

The results presented in this report are for nine Precipitate Hydrolysis Aqueous (PHA) Phase 4 glasses. Three of the glasses contained HM sludge at 22, 26, and $30 \mathrm{wt} \%$ respectively, $10 \mathrm{wt} \%$ PHA and 1.25 wt\% monosodium titanate (MST), all on an oxide basis. The remaining six glasses were selected from the Phase 1 and Phase 2 studies (Purex sludge) but with an increased amount of MST. The high-end target for MST of $2.5 \mathrm{wt} \%$ oxide was missed in Phases 1 and 2 due to -30 wt $\%$ water content of the MST. A goal of this Phase 4 study was to determine whether this increase in titanium concentration from the MST had any impact on glass quality or processibility. Two of the glasses, pha14c and pha15c, were rebatched and melted due to apparent batching errors with pha14 and pha15:

The models currently in the Defense Waste Processing Facility's (DWPF's) Product Composition Control System (PCCS) were used to predict durability, homogeneity, liquidus, and viscosity for these nine glasses. All of the HM glasses and half of the Purex glasses were predicted to be phase separated, and consequently prediction of glass durability is precluded with the current models for those glasses that failed the homogeneity constraint. If one may ignore the homogeneity constraint, the measured durabilities were within the $95 \%$ prediction limits of the model. Further efforts will be required to resolve thîs issue on phase separation (inhomogeneity).

The liquidus model predicted unacceptable liquidus temperatures for four of the nine glasses. The approximate, bounding liquidus temperatures measured for all had upper limits of $1000^{\circ} \mathrm{C}$ or less. Given the fact that liquidus temperatures were only approximated, the $30 \mathrm{wt} \%$ loading of Purex may be near or at the edge of acceptability for liquidus.

The measured viscosities were close to the predictions of the model. For the Purex glasses, pha12c and pha15c, the measured viscosities of 28 and 23 poise, respectively, indicate that DWPF processing may be compromised at the low end of the viscosity range (20 poise). Although the HM sludge glass examined (10 wt $\%$ PHA) had a measured viscosity of $\sim 90$ poise, the $\mathrm{HM}$ glasses at $7 \mathrm{wt} \%$ PHA are predicted to be higher than the 100 poise limit for DWPF. Further work will be required to resolve these issues.

\section{INTRODUCTION}

One of the Alternative Salt Disposition Flowsheets being considered would require that the Defense Waste Processing Facility (DWPF) vitrify a coupled feed containing high level waste (HLW) and Precipitate Hydrolysis Aqueous, PHA. A Technical Task Request (TTR) [1] was received by the Savannah River Technology Center (SRTC) requesting that a glass variability study be conducted to explore the processability and product quality of the glass composition region for this alternative to the In-Tank Precipitation (ITP) Process. A Task Technical and Quality Assurance (TT\&QA) plan [2] was issued by SRTC in response to the TTR. The objective of this task is to obtain information on the feasibility of incorporating anticipated levels of PHA into DWPF glass with and without doubling the nominal levels of monosodium titanate (MST).

A set of target compositions from which the glasses supporting this task are to be selected was provided in the memorandum appearing as Attachment I in [3]. Process and product property predictions for these glasses are also provided in that memorandum. The candidate glasses identified in that memorandum involved three sludge types: Purex, HM, and Blend; covered sludge loadings (in the glass) of 22, 26, and 30 oxide weight percent (wt\%); utilized PHA loadings (in the glass) of 7, 10, and 13 oxide wt\%; and included MST concentrations (in the glass) at 1.25 and $2.5 \mathrm{wt} \%$. For each composition, the remainder of the glass consisted of Frit 202. The glasses, batched and fabricated using the Purex sludge at a target loading of 26,30 and $22 \mathrm{wt} \%$ of the glass, were selected to comprise Phase 1, 2, and 3, respectively, of this study and were reported in [3], [4], and [5], respectively. In Phase 4, the final phase of this study, some of the compositions (derived from Purex sludge) that were considered in the first three phases were revisited to resolve concerns that arose during these earlier investigations. In addition, three compositions derived from HM sludge were considered in this phase 
of the study. The general, target compositions of the glasses initially considered in Phase 4 are provided in Table 1.

Table 1: General Composition of the PHA Phase 4 Glasses

\begin{tabular}{|cccccc|}
\hline Glass ID & $\begin{array}{c}\text { Sludge } \\
\text { Type }\end{array}$ & $\begin{array}{c}\text { Sludge } \\
\text { Loading }\end{array}$ & PHA & MST & Frit \\
pha20 & HM & $22 \%$ & $10 \%$ & $1.25 \%$ & $66.75 \%$ \\
pha26 & HM & $26 \%$ & $10 \%$ & $1.25 \%$ & $62.75 \%$ \\
pha32 & HM & $30 \%$ & $10 \%$ & $1.25 \%$ & $58.75 \%$ \\
pha11c & Purex & $26 \%$ & $10 \%$ & $2.5 \%$ & $61.50 \%$ \\
pha12c & Purex & $26 \%$ & $13 \%$ & $2.5 \%$ & $58.50 \%$ \\
pha17c & Purex & $30 \%$ & $10 \%$ & $2.5 \%$ & $57.50 \%$ \\
pha18c & Purex & $30 \%$ & $13 \%$ & $2.5 \%$ & $54.50 \%$ \\
\hline
\end{tabular}

The glass identifiers used for these compositions include a "c" suffix for each of those glasses that are being re-batched for Phase 4 of this study. The MST used during the earlier phases of this study contained excess moisture that was not fully accounted for in the batching process resulting in $\mathrm{TiO}_{2}$ levels in the glass falling somewhat short of their intended targets. Thus, one objective for Phase 4 is to ensure that no problems are seen for glasses fully loaded with (i.e., with targets met for) $\mathrm{TiO}_{2}$.

The properties of interest for these glasses included durability (as measured by the 7-day Product Consistency Test (PCT) [6]), viscosity at $1150^{\circ} \mathrm{C}$, and liquidus temperature. The purpose of this report is to provide and investigate comparisons between

- the measured and target compositions of this set initial of Phase 4 PHA glasses and

- the property measurements and their predictions.

Phase 4 is the last of the investigative efforts for this PHA glass study

\section{RESULTS AND DISCUSSION}

The initial seven glasses comprising Phase 4 of the PHA study were designated as pha20, pha26, pha32, pha1 lc, pha12c, pha17c, and pha18c. Composition and property measurements of these glasses were conducted in parallel with the seven glasses comprising Phase 4 of the other ITP replacement alternative designated as the Crystalline Silicotitanate (CST) study [7]. This helps ensure that the CST and PHA glasses are fabricated, characterized, and analyzed under very similar conditions. The analytical plans that were used to generate the measurements required to support both (CST and PHA) studies appear as attachments to [7], [8], and [9]. These plans, which are identified in the discussion that follows, were prepared to support the overall Technical Task and QA plan [2] and the analytical study plan [10]. The results of these measurements (both composition and property) are presented in this section.

\section{Chemical Compositions}

Table 2 provides the target oxide compositions for all candidate PHA glasses using Purex sludge. Table 3 provides the composition of the three HM glasses included in Phase 4. See Attachment I of [3] for details on the development of these target compositions. The Glass ID column can be used to identify the rows of Table 2 corresponding to the compositions of the Phase 4 glasses, if the "c" suffix is ignored. 
Table 2: Target Oxide Composition (in weight percents, wt\%'s) of the PHA Glasses Fabricated with Purex Sludge

\begin{tabular}{|c|c|c|c|c|c|c|c|c|c|c|c|c|c|c|c|c|}
\hline \multicolumn{17}{|c|}{ Glass } \\
\hline Sludge & MST & PHA & Frit 202 & ID & $\mathrm{Al}_{2} \mathrm{O}_{3}$ & $\mathrm{~B}_{2} \mathrm{O}_{3}$ & $\mathbf{B a O}$ & $\mathrm{CaO}$ & $\mathrm{Cr}_{2} \mathrm{O}_{3}$ & $\mathrm{CuO}$ & $\mathrm{Fe}_{2} \mathrm{O}_{3}$ & $\mathbf{K}_{2} \mathbf{O}$ & $\mathrm{Li}_{2} \mathbf{O}$ & $\mathrm{MgO}$ & $\mathrm{MnO}$ & $\mathrm{Na}_{2} \mathrm{O}$ \\
\hline 22 & 1.250 & 7 & 69.750 & pha01 & 2.540 & 7.974 & 0.084 & 0.945 & 0.106 & 0.568 & 9.899 & 3.350 & 4.785 & 1.448 & 1.727 & 7.869 \\
\hline 22 & 1.250 & 10 & 66.750 & pha02 & 2.522 & 8.803 & 0.084 & 0.941 & 0.106 & 0.791 & 9.897 & 4.730 & 4.579 & 1.389 & 1.727 & 8.017 \\
\hline 22 & 1.250 & 13 & 63.750 & pha03 & 2.504 & 9.632 & 0.084 & 0.936 & 0.106 & 1.014 & 9.894 & 6.110 & 4.373 & 1.329 & 1.727 & 8.165 \\
\hline 22 & 2.500 & 7 & 68.500 & pha04 & 2.532 & 7.876 & 0.084 & 0.943 & 0.106 & 0.568 & 9.898 & 3.350 & 4.699 & 1.423 & 1.727 & 7.944 \\
\hline 22 & 2.500 & 10 & 65.500 & pha05 & 2.514 & 8.705 & 0.084 & 0.939 & 0.106 & 0.791 & 9.896 & 4.730 & 4.493 & 1.364 & 1.727 & 8.092 \\
\hline 22 & 2.500 & 13 & 62.500 & pha06 & 2.496 & 9.534 & 0.084 & 0.934 & 0.106 & 1.014 & 9.893 & 6.110 & 4.288 & 1.304 & 1.727 & 8.240 \\
\hline 26 & 1.250 & 10 & 62.750 & pha08 & 2.883 & 8.488 & 0.099 & 1.088 & 0.125 & 0.800 & 11.683 & 4.745 & 4.305 & 1.322 & 2.041 & 8.264 \\
\hline 26 & 1.250 & 13 & 59.750 & pha09 & 2.865 & 9.317 & 0.099 & 1.083 & 0.125 & 1.023 & 11.681 & 6.125 & 4.099 & 1.262 & 2.041 & 8.412 \\
\hline 26 & 2.500 & 7 & 64.500 & phalo & 2.894 & 7.561 & 0.099 & 1.090 & 0.125 & 0.576 & 84 & 65 & 4.425 & 1.356 & 2.041 & 8.191 \\
\hline 26 & 2.500 & 10 & 61.500 & pha11 & 2.876 & 8.390 & 0.099 & 1.086 & 0.125 & 0.800 & 11.682 & 4.745 & 4.219 & 1.297 & 2.041 & 8.339 \\
\hline 26 & 2.500 & 13 & 58.500 & pha12 & 2.858 & 9.219 & 0.099 & 1.081 & 0.125 & 1.023 & 11.680 & 6.125 & 4.013 & 1.237 & 2.041 & 8.487 \\
\hline 30 & 1.250 & 7 & 61.750 & pha13 & 3.263 & 7.345 & 0.114 & 1.239 & 0.144 & 0.585 & 13.472 & 3.380 & 4.236 & 1.314 & 2.355 & 8.363 \\
\hline 30 & 1.250 & 10 & 58.750 & phal4 & 3.245 & 8.174 & 0.114 & 1.234 & 0.144 & 0.808 & 13.470 & 4.760 & 4.030 & 1.255 & 2.355 & 8.511 \\
\hline 30 & 1.250 & 13 & 55.750 & pha1s & 3.227 & 9.003 & 0.114 & 1.230 & 0.144 & 1.031 & 13.467 & 6.140 & 3.824 & 1.195 & 2.355 & 8.659 \\
\hline 30 & 2.500 & 10 & 57.500 & phal7 & 3.238 & 8.075 & 0.114 & 1.233 & 0.144 & 0.808 & 13.469 & 4.759 & 3.945 & 1.230 & 2.355 & 8.586 \\
\hline 30 & $2.500^{-}$ & 13 & 54.500 & pha18 & 3.220 & 8.904 & 0.114 & 1.228 & 0.144 & 1.031 & 13.466 & 6.139 & 3.739 & 1.170 & 2.355 & 8.734 \\
\hline
\end{tabular}

Table 2: Target Oxide Composition (in weight percents, wt\%'s)

of the PHA Glasses Fabricated with Purex Sludge (continued)

\begin{tabular}{|c|c|c|c|c|c|c|c|c|c|c|c|c|c|c|c|}
\hline Sludge & MST & PHA & Frit 202 & $\begin{array}{c}\text { Glass } \\
\text { ID }\end{array}$ & $\mathrm{NiO}$ & $\dot{\mathbf{P}}_{2} \mathrm{O}_{5}$ & $\mathbf{P b O}$ & $\mathrm{SiO}_{2}$ & $\mathrm{TiO}_{2}$ & $\mathrm{U}_{3} \mathrm{O}_{8}$ & $\mathrm{ZnO}$ & $\mathrm{ZrO}$ & $\mathbf{F}$ & $\mathrm{Cl}^{-}$ & $\left(\mathrm{SO}_{4}\right)^{*}$ \\
\hline $22^{\circ}$ & 1.250 & 7 & 69.750 & pha01 & 0.930 & 0.030 & 0.096 & 53.684 & 1.128 & 2.003 & 0.086 & 0.109 & 0.032 & 0.240 & 0.173 \\
\hline 22 & 1.250 & 10 & 66.750 & phaO2 & 0.930 & 0.030 & 0.096 & 51.404 & 1.127 & 2.003 & 0.086 & 0.109 & 0.032 & 0.240 & 0.173 \\
\hline 22 & 1.250 & 13 & 63.750 & pha03 & 0.930 & 0.030 & 0.096 & 49.124 & 1.125 & 2.003 & 0.086 & 0.109 & 0.032 & 0.240 & 0.173 \\
\hline 22 & 2.500 & 7 & 68.500 & pha04 & 0.930 & 0.030 & 0.096 & 52.734 & 2.226 & 2.003 & 0.086 & 0.109 & 0.032 & 0.240 & 0.173 \\
\hline 22 & 2.500 & 10 & 65.500 & pha05 & 0.930 & 0.030 & 0.096 & 50.454 & 2.225 & 2.003 & 0.086 & 0.109 & 0.032 & 0.240 & 0.173 \\
\hline 22 & 2.500 & 13 & 62.500 & pha06 & 0.930 & 0.030 & 0.096 & 48.174 & 2.224 & 2.003 & 0.086 & 0.109 & 0.032 & 0.240 & 0.173 \\
\hline 26 & 1.250 & 7 & 65.750 & pha07 & 1.099 & 0.036 & 0.114 & 50.766 & 1.126 & 2.367 & 0.102 & 0.129 & 0.038 & 0.283 & 0.205 \\
\hline 26 & 1.250 & 10 & 62.750 & pha08 & 1.099 & 0.036 & 0.114 & 48.486 & 1.125 & 2.367 & 0.102 & 0.129 & 0.038 & 0.283 & 0.205 \\
\hline 26 & 1.250 & 13 & 59.750 & pha09 & 1.099 & 0.036 & 0.114 & 46.206 & 1.124 & 2.367 & 0.102 & 0.129 & 0.038 & 0.283 & 0.205 \\
\hline 26 & 2.500 & 7 & 64.500 & pha10 & 1.099 & 0.036 & 0.114 & 49.816 & 2.224 & 2.367 & 0.102 & 0.129 & 0.038 & 0.283 & 0.205 \\
\hline 26 & 2.500 & 10 & 61.500 & pha11 & 1.099 & 0.036 & 0.114 & 47.536 & 2.223 & 2.367 & 0.102 & 0.129 & 0.038 & 0.283 & 0.205 \\
\hline 26 & 2.500 & 13 & 58.500 & pha12 & 1.099 & 0.036 & 0.114 & 45.256 & 2.222 & 2.367 & 0.102 & 0.129 & 0.038 & 0.283 & 0.205 \\
\hline 30 & 1.250 & 7 & 61.750 & pha13 & 1.268 & 0.041 & 0.132 & 47.849 & 1.125 & 2.731 & 0.118 & 0.149 & 0.043 & 0.327 & 0.236 \\
\hline 30 & 1.250 & 10 & 58.750 & phal4 & 1.268 & 0.041 & 0.132 & 45.569 & 1.123 & 2.731 & 0.118 & 0.149 & 0.043 & 0.327 & 0.236 \\
\hline 30 & 1.250 & 13 & 55.750 & pha15 & 1.268 & 0.041 & 0.132 & 43.289 & 1.122 & 2.731 & 0.118 & 0.149 & 0.043 & 0.327 & 0.236 \\
\hline 30 & 2.500 & 7 & 60.500 & phal6 & 1.268 & 0.041 & 0.132 & 46.899 & 2.223 & 2.731 & 0.118 & 0.149 & 0.043 & 0.327 & 0.236 \\
\hline 30 & 2.500 & 10 & 57.500 & phal7 & 1.268 & 0.041 & 0.132 & 44.619 & 2.221 & 2.731 & 0.118 & 0.149 & 0.043 & 0.327 & 0.236 \\
\hline 30 & 2.500 & 13 & 54.500 & pha18 & 1.268 & 0.041 & 0.132 & 42.339 & 2.220 & 2.731 & 0.118 & 0.149 & 0.043 & 0.327 & 0.236 \\
\hline
\end{tabular}

Table 3: Target Compositions of PHA Phase 4 HM Glasses

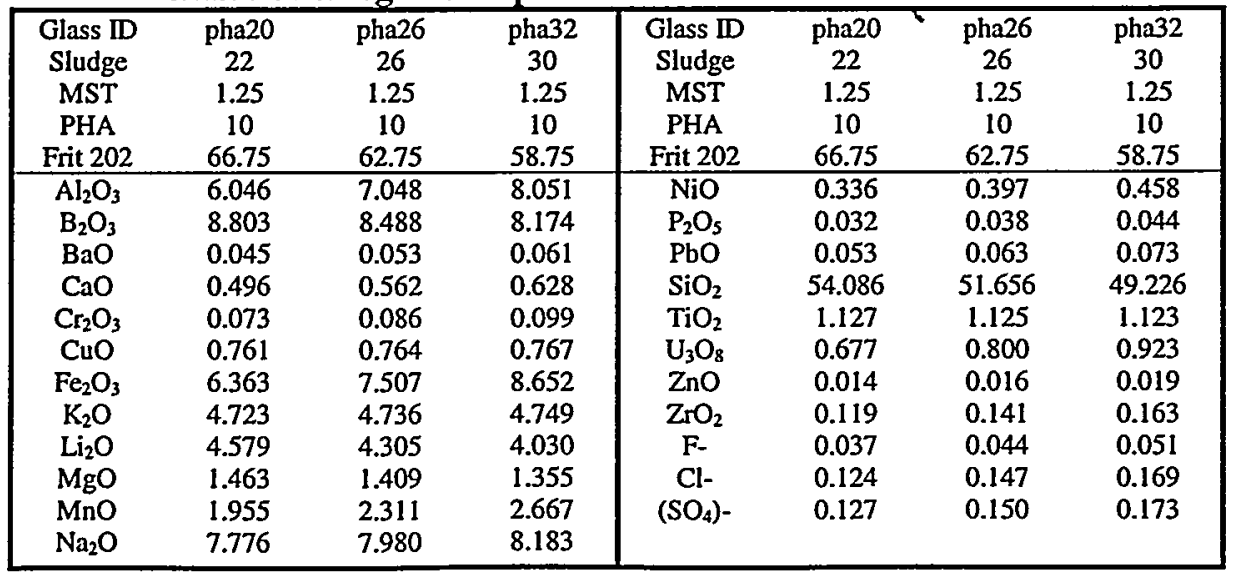


Predictions for the properties of interest generated for these target compositions by the models utilized by the Defense Waste Processing Facility (DWPF) are also included in the discussion provided in Attachment I of [3]. These properties, for a given composition, relate to its processability and its product quality. For a given composition, acceptable property characteristics and reliable property predictions (using the current DWPF models) are of interest. Comparisons between property predictions and property measurements are provided for these Phase 4 PHA glasses in the discussion that follows.

The initial seven glasses were batched and fabricated to the target compositions corresponding to the appropriate rows of Table 2 and to Table 3. In addition to the Phase 4 glasses (both CST and PHA), a standard glass (WCP Batch 1) and a standard uranium-bearing glass were included in the planning of these analyses (for possible bias correction). An analytical plan (in the form of a memorandum) was provided to assist the SRTC-Mobile Laboratory (SRTC-ML) in conducting these analyses (see Attachment I of [8]). Due to outages at this laboratory, these glasses were subsequently submitted to the Analytical Development Section (ADS) of SRTC for chemical composition analysis.

Glasses were batched using the appropriate combinations of Purex sludge, glass formers, PHA, and MST. .The simulated Purex and HM sludges were batched from dry chemicals and have oxide compositions provided in Attachment I of [3]. PHA was batched from chemicals and has an oxide composition provided in Table 2 of Attachment I of [3]. A basic MST solution was obtained from D. Hobbs. This material was washed and then dried. The composition of MST was determined by the Mobile Lab and is presented in Table 1 of Attachment I of [3]. Frit 202, Lot 14 was obtained from the DWPF. The Frit 202 composition is given in Table 7 of Attachment I of [3].

For each glass, the combined powders $(-120$ grams $)$ were added to a $250 \mathrm{~mL} \mathrm{Pt}-\mathrm{Au}$ crucible and placed in a calibrated furnace, heated to $1150^{\circ} \mathrm{C}$ at a rate of $10^{\circ} \mathrm{C} /$ minute, and then held for four hours at $1150^{\circ} \mathrm{C}$. The crucible was then removed, and the glass immediately poured onto a clean stainless steel plate.

Tables A.1 and A.2 in Appendix A provide the composition measurements obtained by ADS following an analytical plan similar to that provided in Attachment $I$ of [8]. ${ }^{1}$ Two types of dissolutions (microwave and peroxide fusion) were used to generate these composition measurements. Table A.1 provides the peroxide fusion (pf) results and Table A.2 the microwave (MW) results. Calcium and silicon cation concentrations were measured using both preparation methods.

Exhibit A.1 in Appendix A provides a plot of the measurements by glass sample id by oxide. The results for pha26 call for a closer look at each of the microwave dissolutions. They are provided in Table 4.

\begin{tabular}{|c|c|c|c|}
\hline Oxide & Prep 1 & Prep 2 & Target \\
\hline Al2O3 (wt\%) & 2.777 & 6.453 & 7.048 \\
\hline $\mathrm{CaO} \mathrm{MW}(\mathrm{wt} \%)$ & 0.997 & 0.514 & 0.562 \\
\hline $\mathrm{Cr} 2 \mathrm{O} 3(\mathrm{wt} \%)$ & 0.163 & 0.120 & 0.086 \\
\hline $\mathrm{CuO}(\mathrm{wt} \%)$ & 0.795 & 0.691 & 0.764 \\
\hline $\mathrm{Fe} 2 \mathrm{O} 3(\mathrm{wt} \%)$ & 10.137 & 7.348 & 7.507 \\
\hline $\mathrm{K} 2 \mathrm{O}(\mathrm{wt} \%)$ & 4.485 & 4.445 & 4.736 \\
\hline $\mathrm{Li} 20$ (wt\%) & 4.862 & 4.391 & 4.305 \\
\hline $\mathrm{MgO}(\mathrm{wt} \%)$ & 1.442 & 1.286 & 1.409 \\
\hline $\mathrm{MnO}(\mathrm{wt} \%)$ & 2.029 & 2.320 & 2.311 \\
\hline $\mathrm{Na} 2 \mathrm{O}$ (wt\%) & 8.374 & 7.952 & 7.980 \\
\hline $\mathrm{Nb} 2 \mathrm{O} 5$ (wt\%) & 0.074 & 0.072 & 0.000 \\
\hline $\mathrm{NiO}(\mathrm{wt} \%)$ & 0.925 & 0.377 & 0.397 \\
\hline SiO2 MW (wt\%) & 49.471 & 49.100 & 51.656 \\
\hline $\mathrm{TiO} 2(w t \%)$ & 1.219 & 1.173 & 1.125 \\
\hline U3O8 (wt\%) & 1.917 & 0.954 & 0.800 \\
\hline $\mathrm{ZrO} 2(w t \%)$ & 0.197 & 0.171 & 0.141 \\
\hline
\end{tabular}

1 The dissolved samples were prepared according to the plan, and then ADS LIMS numbers were randomly assigned to the dissolved samples. 
Due to the inconsistency between the results for the two microwave dissolutions (and considering the target composition), the results from the first dissolution are deemed unrepresentative and excluded from further consideration in this report.

A review of the results from the standards was conducted for insight into the possibility that the ICP calibration contributes (in a systematic way) to the variation seen in the oxide measurements for the Phase 4 glasses. Exhibits A.2 and A.3 in Appendix A provide plots of the oxide measurements per analytical block by oxide by dissolution method. Table 5 provides the average measured composition for the two types of standards included in this analytical plan by analytical block. The reference values for the standards are also provided in this table.

Table 5: Measurements from Glass Standards from Phase 4

\begin{tabular}{|c|c|c|c|c|c|c|}
\hline & \multicolumn{2}{|c|}{ std (Batch 1) } & \multirow[b]{3}{*}{ Reference } & \multicolumn{3}{|c|}{ Ustd (Uranium-bearing Standard) } \\
\hline & \multicolumn{2}{|c|}{ Analytical Block } & & \multicolumn{2}{|c|}{ Analytical Block } & \multirow[b]{2}{*}{ Reference } \\
\hline & 1 & 2 & & 1 & 2 & \\
\hline Oxide & 3 obs & 3 obs & Value & 2 obs & 2 obs & Value \\
\hline $\mathrm{Al}_{2} \mathbf{O}_{3}$ & 4.853 & 4.895 & 4.877 & 4.002 & 4.021 & 4.100 \\
\hline $\mathbf{B}_{2} \mathbf{O}_{3}$ & 7.640 & 7.899 & 7.777 & 10.015 & 9.937 & 9.209 \\
\hline CaO (pf) & 1.621 & 1.588 & 1.220 & 1.644 & 1.747 & 1.301 \\
\hline $\mathrm{CaO}(\mathrm{MW})$ & 1.240 & 1.244 & 1.220 & 1.309 & 1.312 & 1.301 \\
\hline $\mathrm{CaO}$ (avg) & 1.431 & 1.416 & 1.220 & 1.477 & 1.530 & 1.301 \\
\hline $\mathrm{Cr}_{2} \mathrm{O}_{3}$ & 0.105 & 0.108 & 0.107 & 0.261 & 0.259 & 0.000 \\
\hline $\mathrm{CuO}$ & 0.400 & 0.403 & 0.399 & 0.013 & 0.014 & 0.000 \\
\hline $\mathrm{Fe}_{2} \mathrm{O}_{3}$ & 13.384 & 13.493 & 12.839 & 13.836 & 13.863 & 13.196 \\
\hline $\mathrm{K}_{2} \mathrm{O}$ & 3.002 & 3.348 & 3.327 & 2.813 & 3.013 & 2.999 \\
\hline $\mathrm{Li}_{2} \mathrm{O}$ & 4.581 & 4.608 & 4.429 & 3.133 & 3.136 & 3.057 \\
\hline MgO & 1.442 & 1.450 & 1.419 & 1.197 & 1.199 & 1.210 \\
\hline $\mathrm{MnO}$ & 1.737 & 1.741 & 1.726 & 2.809 & 2.798 & 2.892 \\
\hline $\mathrm{Na}_{2} \mathrm{O}$ & 9.223 & 9.265 & 9.003 & 12.083 & 12.083 & 11.795 \\
\hline $\mathrm{Nb}_{2} \mathrm{O}_{5}$ & 0.070 & 0.070 & 0.000 & 0.073 & 0.073 & 0.000 \\
\hline $\mathrm{NiO}$ & 0.780 & 0.786 & 0.751 & 1.104 & 1.114 & 1.120 \\
\hline $\mathrm{SiO}_{2}$ (pf) & 50.906 & 52.733 & 50.220 & 51.893 & 51.505 & 45.353 \\
\hline $\mathrm{SiO}_{2}(\mathrm{MW})$ & 47.740 & 47.807 & 50.220 & 43.466 & 43.463 & 45.353 \\
\hline $\mathrm{SiO}_{2}$ (avg) & 49.323 & 50.270 & 50.220 & 47.680 & 47.484 & 45.353 \\
\hline $\mathrm{TiO}_{2}$ & 0.700 & 0.704 & 0.677 & 1.014 & 1.015 & 1.049 \\
\hline $\mathrm{U}_{3} \mathrm{O}_{8}$ & 0.340 & 0.340 & 0.000 & 2.404 & 2.377 & 2.406 \\
\hline $\mathrm{ZrO}_{2}$ & 0.121 & 0.123 & 0.098 & 0.009 & 0.010 & 0.000 \\
\hline Sum of Oxides & 99.132 & 100.919 & 98.869 & 103.922 & 103.927 & 99.687 \\
\hline
\end{tabular}

The analytical results from the Batch 1 samples were used to bias-correct for a possible ICP calibration effect (a block effect) in the other measurements. ${ }^{2}$ This was accomplished for each oxide in turn by taking the original oxide measurement, noting its block, and then multiplying the measurement by the ratio of the corresponding reference value for Batch 1 divided by the average oxide measurement for Batch 1 in that block. The calcium and silicon values for each dissolution method were adjusted via this process. This approach was used to bias-correct the composition measurements of the Phase 3 and standard glasses.

Exhibit A.4 in Appendix A provides plots of these measurements for each oxide over all of the glasses (including the standards), and Table 6 provides summary information for these measurements. The sums of oxides for the target, measured, and measured bias-corrected (bc) compositions are also provided. A review of these sums shows that they are all within the interval of 95 to 105 weight percent with the smallest value being $96.8 \mathrm{wt} \%$ for the bias-corrected composition of pha32 and the largest being 103.9 for the uranium-bearing glass standard.

Bias corrections of this type have been advantageous (see for example "A Statistical Review of Data from the SRTC Mobile Laboratory," WSRC-RP-98-00430, Revision 0, June 15, 1998) but not always. In some instances, bias correction does not improve the accuracy of the results. Measurements are bias-corrected in this report, and bias-corrected vales are considered in the comparisons that follow. Conclusions, developed from these comparisons, that are insensitive to the way the glass compositions are represented (target, measured, or bias-corrected) demonstrate robustness to which representation might be nearer the true composition for each glass. 
Another observation from this exhibit and table is the closeness of the $\mathrm{TiO}_{2}$ measurements to their respective targets for these PHA glasses. A problem was seen in Phases 1 [3] and 2 [4]. Namely, the $\mathrm{TiO}_{2}$ measurements for the PHA glasses fell short of their respective target values for the first two phases even though the measurements for the standards compared very favorably to their targets. This behavior prompted a re-evaluation a source of $\mathrm{TiO}_{2}$, the MST. A subsequent analysis of MST revealed a larger than expected moisture content $(-30 \mathrm{wt} \%)$. However, as discussed in [3], glasses for Phases 1 and 2 were batched and fabricated prior to this discovery. Batching formulations were subsequently modified to account for the additional loss that would be expected for this situation. Glasses for Phases 3 and 4 were batched in a manner fully accounting for the additional moisture. In addition, Phase 4 included selected glasses from Phases 1 (pha11c and pha12c) and 2 (pha17c and pha18c) that were re-batched using the new formulations. The results from Table 6 and Exhibit A.4 indicate that better coverage was achieved for the higher MST loadings for these phases and that the MST loadings were successfully targeted for the glasses of this phase.

Table 6: Target, Measured and Bias-Corrected Compositions (in wt\%) for the Phase 4 Glasses

\begin{tabular}{|c|c|c|c|c|c|c|c|c|c|}
\hline$=$ & \multicolumn{3}{|c|}{ Batch I } & \multicolumn{3}{|c|}{ Uranium Standard (Ustd) } & \multicolumn{3}{|c|}{ phallc } \\
\hline & Target & Measured & Bias-cor. & Target & Meas. & Bias-cor. & Target & Measured & Bias-cor. \\
\hline $\mathrm{Al}_{2} \mathrm{O}_{3}$ & 4.877 & 4.874 & 4.877 & 4.100 & 4.011 & 4.014 & 2.876 & 2.783 & 2.784 \\
\hline $\mathrm{B}_{2} \mathrm{O}_{3}$ & 7.777 & 7.769 & 7.777 & 9.209 & 9.976 & 9.990 & 8.390 & 8.420 & 8.429 \\
\hline $\mathrm{CaO}$ & 1.220 & 1.423 & 1.220 & 1.301 & 1.503 & 1.289 & 1.086 & 1.118 & 0.966 \\
\hline $\mathrm{Cr}_{2} \mathrm{O}_{3}$ & 0.107 & 0.107 & 0.107 & 0.000 & 0.260 & 0.261 & 0.125 & 0.156 & 0.156 \\
\hline $\mathrm{CuO}$ & 0.399 & 0.402 & 0.399 & 0.000 & 0.013 & 0.013 & 0.800 & 0.754 & 0.749 \\
\hline $\mathrm{Fe}_{2} \mathrm{O}_{3}$ & 12.839 & 13.439 & 12.839 & 13.196 & 13.850 & 13.232 & 11.682 & 11.171 & 10.672 \\
\hline $\mathrm{K}_{2} \mathrm{O}$ & 3.327 & 3.175 & 3.327 & 2.999 & 2.913 & 3.055 & 4.745 & 4.109 & 4.307 \\
\hline $\mathbf{L i}_{2} \mathbf{O}$ & 4.429 & 4.594 & 4.429 & 3.057 & 3.135 & 3.022 & 4.219 & 4.403 & 4.245 \\
\hline MgO & 1.419 & 1.446 & 1.419 & 1.210 & 1.198 & 1.175 & 1.297 & 1.295 & 1.270 \\
\hline MnO & 1.726 & 1.739 & 1.726 & 2.892 & 2.804 & 2.783 & 2.041 & 2.067 & 2.052 \\
\hline $\mathrm{Na}_{2} \mathrm{O}$ & 9.003 & 9.244 & 9.003 & 11.795 & 12.083 & 11.768 & 8.339 & 8.310 & 8.094 \\
\hline $\mathrm{NiO}$ & 0.751 & 0.783 & 0.751 & 1.120 & 1.109 & 1.064 & 1.099 & 0.971 & 0.932 \\
\hline $\mathrm{SiO}_{2}$ & 50.220 & 49.796 & 50.220 & 45.353 & 47.582 & 47.906 & 47.536 & 48.730 & 49.149 \\
\hline $\mathrm{TiO}_{2}$ & 0.677 & 0.702 & 0.677 & 1.049 & 1.014 & 0.978 & 2.223 & 2.219 & 2.140 \\
\hline $\mathrm{U}_{3} \mathrm{O}_{8}$ & 0.000 & 0.340 & 0.340 & 2.406 & 2.390 & 2.390 & 2.367 & 2.101 & 2.101 \\
\hline $\mathrm{ZrO}_{2}$ & 0.098 & 0.122 & 0.098 & 0.000 & 0.009 & 0.008 & 0.129 & 0.173 & 0.139 \\
\hline Sum of Oxides & 98.869 & 100.026 & 99.280 & 99.687 & 103.924 & 103.022 & 98.954 & 98.854 & 98.262 \\
\hline & & phaI2c & & & phal7c & & & pha18c & \\
\hline & Tarant & Megsured & Measured & Taraet & Megsured & Measured & Taroet & sured & Measured \\
\hline $\mathrm{Al}_{2} \mathrm{O}_{3}$ & 2.858 & 2.705 & 2.707 & 3.238 & $\begin{array}{r}3.065 \\
\end{array}$ & 3.067 & $\begin{array}{r}\text { arget } \\
3.220\end{array}$ & $\begin{array}{r}\text { surea } \\
3.458\end{array}$ & $\begin{array}{l}\text { secor. } \\
3.460\end{array}$ \\
\hline $\mathrm{B}_{2} \mathrm{O}_{3}$ & 9.219 & 9.283 & 9.297 & 8.075 & 7.763 & 7.770 & 8.904 & 8.998 & 9.007 \\
\hline $\mathrm{CaO}$ & 1.081 & 1.159 & 0.999 & 1.233 & 1.270 & 1.093 & 1.228 & 1.361 & 1.179 \\
\hline $\mathrm{Cr}_{2} \mathrm{O}_{3}$ & 0.125 & 0.146 & 0.146 & 0.144 & 0.182 & 0.183 & 0.144 & 0.180 & 0.180 \\
\hline $\mathrm{CuO}$ & 1.023 & 0.991 & 0.985 & 0.808 & 0.773 & 0.768 & 1.031 & 1.081 & 1.074 \\
\hline $\mathrm{Fe}_{2} \mathrm{O}_{3}$ & 11.680 & 11.348 & 10.842 & 13.469 & 13.470 & 12.869 & 13.466 & 13.985 & 13.361 \\
\hline $\mathbf{K}_{2} \mathrm{O}$ & 6.125 & 5.397 & 5.661 & 4.759 & 4.510 & 4.733 & 6.139 & 5.399 & 5.662 \\
\hline $\mathrm{Li}_{2} \mathrm{O}$ & 4.013 & 4.280 & 4.126 & 3.945 & 4.024 & 3.879 & 3.739 & 3.907 & 3.767 \\
\hline $\mathrm{MgO}$ & 1.237 & 1.248 & 1.224 & 1.230 & 1.091 & 1.070 & 1.170 & 1.202 & 1.180 \\
\hline MnO & 2.041 & 1.984 & 1.969 & 2.355 & 2.659 & 2.639 & 2.355 & 2.617 & 2.598 \\
\hline $\mathrm{Na}_{2} \mathrm{O}$ & 8.487 & 8.510 & 8.289 & 8.586 & 8.208 & 7.994 & 8.734 & 9.046 & 8.810 \\
\hline $\mathrm{NiO}$ & 1.099 & 0.980 & 0.940 & 1.268 & 1.200 & 1.152 & 1.268 & 1.207 & 1.158 \\
\hline $\mathrm{SiO}_{2}$ & 45.256 & 46.927 & 47.333 & 44.619 & 44.409 & 44.795 & 42.339 & 42.936 & 43.322 \\
\hline $\mathrm{TiO}_{2}$ & 2.222 & 2.222 & 2.143 & 2.221 & 2.291 & 2.210 & 2.220 & 2.319 & 2.237 \\
\hline $\mathrm{U}_{3} \mathrm{O}_{8}$ & 2.367 & 2.328 & 2.328 & 2.731 & 2.111 & 2.111 & 2.731 & 2.274 & 2.274 \\
\hline $\mathrm{ZrO}_{2}$ & 0.129 & 0.155 & 0.125 & 0.149 & 0.181 & 0.145 & 0.149 & 0.181 & 0.146 \\
\hline Sum of Oxides & 98.962 & 99.737 & 99.187 & 98.830 & 97.280 & 96.551 & 98.837 & 100.226 & 99.490 \\
\hline
\end{tabular}


Table 6: Target, Measured and Bias-Corrected Compositions (in wt \%) for the Phase 4 Glasses (continued)

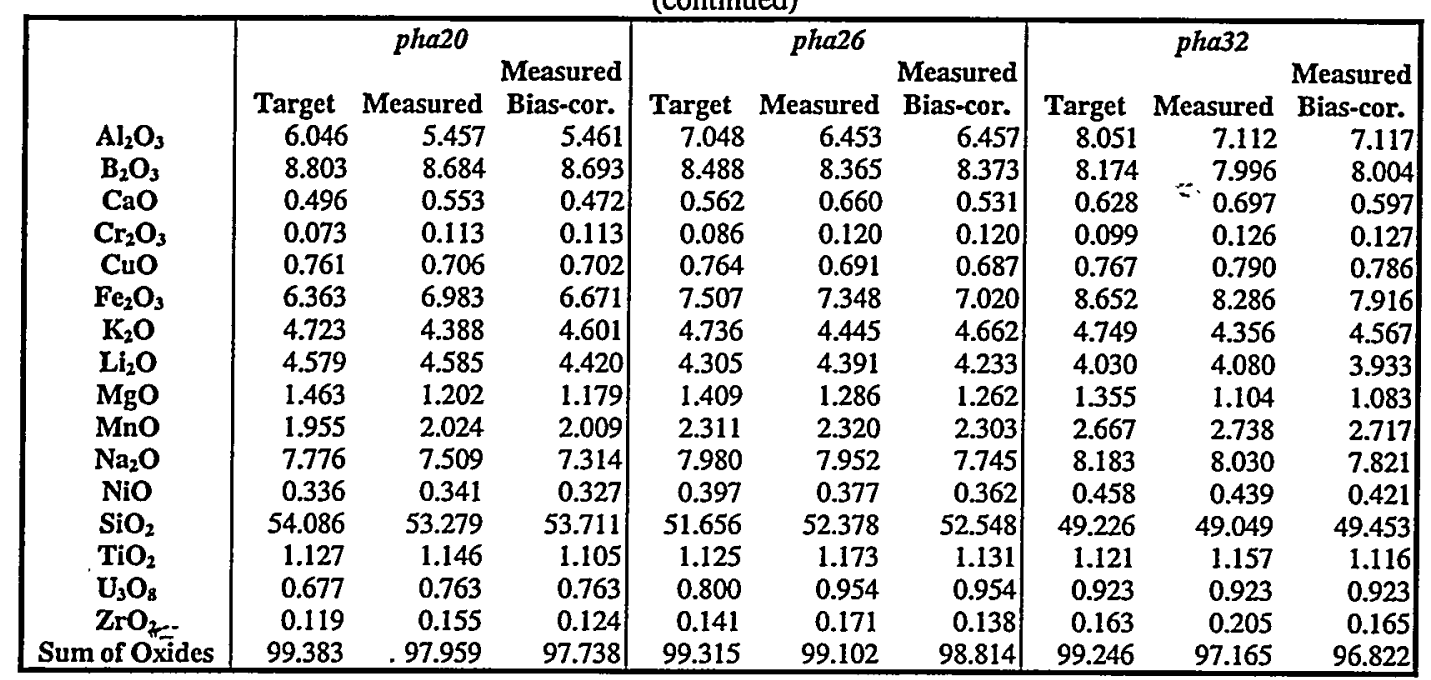

\section{PCT Results}

The seven PHA glasses making up Phase 4, after being batched and fabricated, were subjected to the 7-day Product Consistency Test (PCT) as an assessment of their durabilities [6]. More specifically, Method A of the PCT (ASTM C1285) was used for these measurements. Since durability is the critical product quality metric for vitrified nuclear waste, a review of the PCTs for these glasses was seen as a prerequisite for additional testing of these glasses. The PCTs were to be conducted in triplicate for the Phase 4 glasses. In addition, PCTs were also conducted in triplicate for samples of the Environmental Assessment (EA) glass, the ARM glass, and a blank (ASTM Type I water). An analytical plan supporting these tests was provided in the form of a memorandum (see Attachment II of [9]). This plan was intended to assist the SRTC-ML in measuring the compositions of the solutions resulting from the PHA and CST Phases 3 and 4 PCTs. Due to equipment problems, the SRTC-ML was not able to complete these analyses; they were subsequently completed by the Analytical Development Section (ADS) of SRTC. Of primary interest were the concentrations (in parts per million, ppm) of boron (B), lithium ( $\mathrm{Li}$ ), sodium (Na), and silicon (Si). Samples of a multi-element solution standard were also included in this analytical plan (as a check on the accuracy of the Inductively Coupled Plasma (ICP) - Emission Spectrometer used for these measurements).

The results from these tests are given in Table A.3 of Appendix A. Any measurement determined to be below detection was replaced by its detection limit in subsequent analyses. PCT leachate concentrations are typically normalized using the cation composition (expressed as a weight percent) in the glass to obtain a grams-per-liter $(\mathrm{g} / \mathrm{L})$ leachate concentration. The normalization of the PCTs is usually conducted using the measured compositions of the glasses. This is the preferred normalization process for the PCTs. For completeness, the target cation compositions will also be used to conduct this normalization.

As is the usual convention, the common logarithm of the normalized PCT (normalized leachate, NL) for each element of interest will be determined and used for comparisons. To accomplish this computation, one must

1. Determine the common logarithm of the elemental parts per million (ppm) leachate concentration for each of the triplicates and each of the elements of interest (these values are provided in Table A.3 of Appendix A),

2. Average the common logarithms over the triplicates for each element of interest, and then 
Normalizing Using Measured Composition (preferred method)

3. Subtract a quantity equal to 1 plus the common logarithm of the average cation measured concentration (expressed as a weight percent of the glass) from the average computed in step 2.

Or

Normalizing Using Target Composition

3. Subtract a quantity equal to 1 plus the common logarithm of the target cation concentration (expressed as a weight percent of the glass) from the average computed in step 2 .

As a preliminary step to completing these normalizations of the PCTs, a review of the data was conducted. Exhibit A.5 in Appendix A provides plots of the leachate concentrations by sample id and by element with and without the EA and the blank samples. No problems are seen in these data, in that the results are reasonably consistent across all Phase 4 and standard glasses. Table 7 provides a look at the results from the three analyses of the multi-element standard solution that were included in the analytical-plan. These results also indicate consistent and reasonably accurate results from these analysés.

Table 7: Measurements of Standard Solution

\begin{tabular}{|c|c|c|c|c|c|}
\hline Block & Sequence & B (ppm) & Si (ppm) & $\mathrm{Na}(\mathrm{ppm})$ & $\mathrm{Li}$ (ppm) \\
\hline 1 & 1 & 19.5 & 48.9 & 82.7 & 9.9 \\
\hline 1 & 1 & 19.8 & 49.5 & 84.2 & 10.1 \\
\hline 1 & 1 & $19 . \overline{7}$ & 49.0 & 83.5 & 10.0 \\
\hline Block 1 & average & 19.6 & 49.1 & 83.5 & 10.0 \\
\hline 2 & 2 & $19 . \overline{4}$ & 49.6 & 81.8 & 9.7 \\
\hline 2 & 2 & 19.5 & 49.3 & 81.6 & 9.7 \\
\hline 3 & 2 & 19.4 & 49.2 & 81.4 & 9.7 \\
\hline Block 2 & average & 19.4 & 49.4 & 81.6 & 9.7 \\
\hline 3 & 3 & 19.1 & 48.8 & 80.6 & 9.5 \\
\hline 3 & 3 & 19.3 & 49.0 & 81.5 & 9.6 \\
\hline 3 & 3 & 19.3 & 49.3 & 82.1 & 9.7 \\
\hline Block 3 & average & 19.2 & 49.0 & 81.4 & 9.6 \\
\hline 4 & 4 & 19.2 & 49.0 & 81.8 & 9.7 \\
\hline 4 & 4 & 19.4 & 49.1 & 82.4 & 9.8 \\
\hline 4 & 4 & 19.3 & 49.1 & 82.2 & 9.7 \\
\hline Block 4 & average & 19.3 & 49.1 & 82.1 & 9.7 \\
\hline 5 & 5 & 19.7 & 49.0 & 83.4 & 10.0 \\
\hline 5 & 5 & 19.8 & 49.0 & 83.7 & 10.1 \\
\hline 5 & 5 & 19.8 & 49.0 & 83.7 & 10.1 \\
\hline Block 5 & average & 19.7 & 49.0 & 83.6 & 10.0 \\
\hline 6 & 6 & 19.5 & 48.6 & 83.0 & 10.0 \\
\hline 6 & 6 & 19.6 & 48.6 & 83.3 & 10.0 \\
\hline 6 & 6 & 19.7 & 49.0 & 83.7 & 10.1 \\
\hline Block 6 & average & 19.6 & 48.7 & $83.3^{2}$ & 10.0 \\
\hline Overall & average & 19.5 & 49.0 & 82.6 & 9.9 \\
\hline Reference & Value & 20 & 50 & 81 & 10 \\
\hline$\%$ Difference & & $-2.6 \%$ & $-1.9 \%$ & $2.0 \%$ & $-1.5 \%$ \\
\hline
\end{tabular}

Table 8 provides the results from the normalization process using the information in Table 6 and Table A.3. Exhibit A.6 in Appendix A provides scatter plots for these results offering an opportunity to investigate the consistency in the leaching across the elements for the glasses of this study. This consistency is typically demonstrated by a high degree of linear correlation among the values. For the PCTs normalized using the either target, measured, or bias-corrected compositions, each of these correlations is at least $99 \%$. 
Table 8: Normalized PCTs for Phase 4

\begin{tabular}{|c|c|c|c|c|c|c|c|c|c|}
\hline $\begin{array}{l}\text { Glass ID } \\
\text { ARM } \\
\text { EA }\end{array}$ & $\begin{array}{l}\text { Composition } \\
\text { reference comp. [11] } \\
\text { reference comp. [11] }\end{array}$ & $\begin{array}{c}\log N L \\
{[B(g / L)]} \\
-0.29085 \\
1.28207 \\
\end{array}$ & $\begin{array}{c}\log N L \\
{[S i(g / L)]} \\
-0.54854 \\
0.63353 \\
\end{array}$ & $\begin{array}{c}\log N L \\
{[\mathrm{Na}(\mathrm{g} / \mathrm{L})]} \\
-0.27396 \\
1.18838 \\
\end{array}$ & $\begin{array}{c}\log N L \\
{[\mathrm{Li}(\mathrm{g} / \mathrm{L})]} \\
-0.21652 \\
1.04022 \\
\end{array}$ & $\begin{array}{c}\mathrm{NL} \\
\mathrm{B}(\mathrm{g} / \mathrm{L}) \\
0.51 \\
19.15 \\
\end{array}$ & $\begin{array}{c}\mathrm{NL} \\
\mathrm{Si}(\mathrm{g} / \mathrm{L}) \\
0.28 \\
4.30 \\
\end{array}$ & $\begin{array}{c}N L \\
N a(g / L) \\
0.53 \\
15.43 \\
\end{array}$ & $\begin{array}{c}\mathrm{NL} \\
\mathrm{Li}(\mathrm{g} / \mathrm{L}) \\
0.61 \\
10.97 \\
\end{array}$ \\
\hline \multirow{3}{*}{ phallc } & measured & 0.00658 & -0.27729 & -0.00643 & 0.00240 & 1.02 & 0.53 & 0.99 & 1.01 \\
\hline & measured, bias-cor. & 0.00612 & -0.28101 & 0.00504 & 0.01831 & 1.01 & 0.52 & 1.01 & 1.04 \\
\hline & target & 0.00815 & -0.26651 & -0.00793 & 0.02095 & 1.02 & 0.54 & 0.98 & 1.05 \\
\hline \multirow{3}{*}{ phal2c } & measured & 0.17737 & -0.19919 & 0.15490 & 0.15261 & 1.50 & 0.63 & 1.43 & 1.42 \\
\hline & measured, bias-cor. & 0.17672 & -0.20293 & 0.16637 & 0.16851 & 1.50 & 0.63 & 1.47 & 1.47 \\
\hline & target & 0.18039 & -0.18344 & 0.15610 & 0.18061 & 1.51 & 0.66 & 1.43 & 1.52 \\
\hline \multirow{3}{*}{ pha17c } & measured & 0.08084 & -0.26107 & 0.07914 & 0.06536 & 1.20 & 0.55 & 1.20 & 1.16 \\
\hline & measured, bias-cor. & 0.08047 & -0.26483 & 0.09060 & 0.08127 & 1.20 & 0.54 & 1.23 & 1.21 \\
\hline & target & 0.06374 & -0.26312 & 0.05958 & 0.07393 & 1.16 & 0.55 & 1.15 & 1.19 \\
\hline \multirow{3}{*}{ phal $8 \mathrm{c}$} & measured & 0.24209 & -0.19310 & 0.19460 & 0.20194 & 1.75 & 0.64 & 1.57 & 1.59 \\
\hline & measured, bias-cor. & 0.24166 & -0.19699 & 0.20606 & 0.21784 & 1.74 & 0.64 & 1.61 & 1.65 \\
\hline & target & 0.24667 & -0.18702 & 0.20982 & 0.22103 & 1.76 & 0.65 & 1.62 & 1.66 \\
\hline \multirow{3}{*}{ pha20 } & measured & -0.30200 & -0.52025 & -0.27890 & -0.24396 & 0.50 & 0.30 & 0.53 & 0.57 \\
\hline & measured, bias-cor. & -0.30245 & -0.52376 & -0.26743 & -0.22806 & 0.50 & 0.30 & 0.54 & 0.59 \\
\hline & target & -0.30793 & -0.52678 & -0.29405 & -0.24342 & 0.49 & 0.30 & 0.51 & 0.57 \\
\hline \multirow{3}{*}{ pha26 } & $=$ measured & -0.33060 & -0.54519 & -0.31561 & -0.26829 & 0.47 & 0.28 & 0.48 & 0.54 \\
\hline & -measured, bias-cor. & -0.33098 & -0.54660 & -0.30414 & -0.25238 & 0.47 & 0.28 & 0.50 & 0.56 \\
\hline & target & -0.33691 & -0.53916 & -0.31714 & -0.25972 & 0.46 & 0.29 & 0.48 & 0.55 \\
\hline \multirow{3}{*}{ pha30 } & measured & -0.33341 & -0.53492 & -0.30177 & -0.25942 & 0.46 & 0.29 & 0.50 & 0.55 \\
\hline & sured, bias- & -0.33383 & -0.53848 & -0.29031 & -0.24352 & 0.46 & 0.29 & 0.51 & 0.57 \\
\hline & target & -0.34298 & -0.53649 & -0.30997 & -0.25411 & 0.45 & 0.29 & 0.49 & 0.56 \\
\hline
\end{tabular}

As seen in Table 8, the durabilities for the PHA Phase 4 glasses are much better than that of EA. (This is indicated for each glass by its normalized leachate being much smaller than that of EA.). Figure 1 provides an opportunity for a closer look at these results using measured and bias-corrected compositions. Figure 1 is a plot of the DWPF model that relates the logarithm of the normalized PCT (in this case for $B$ ) to a linear function of a free energy of hydration term $\left(\Delta \mathrm{G}_{\mathrm{p}}, \mathrm{kcal} / 100 \mathrm{~g}\right.$ glass) derived from the glass (measured and bias-corrected) compositions [11]. Prediction limits (at 95\% confidence) for individual PCT results are also plotted around this linear fit. The PCT results for EA (shown as a diamond), ARM (shown as a " $z$ "), and the PHA glasses (each shown as an " $x$ ") are presented on this plot. Note that the PHA results reveal acceptable PCTs that are well predicted by the current DWPF durability model. Figure 2 provides a plot of the boron results based target compositions. Exhibit A.7 in Appendix A provides similar plots of the PHA durability measurements versus the DWPF durability models for $\mathrm{B}, \mathrm{Si}, \mathrm{Na}$, and $\mathrm{Li}$. The behaviors seen in the plots for $\mathrm{Si}, \mathrm{Na}$, and $\mathrm{Li}$ are similar to that demonstrated by the $\mathrm{B}$ results: acceptable and predictable PCTs.

Figure 1.

$\log N L(B)(g / L)$ By del Gp (Using PHA Measured \& Bias-corrected EA and ARM reference compositions)

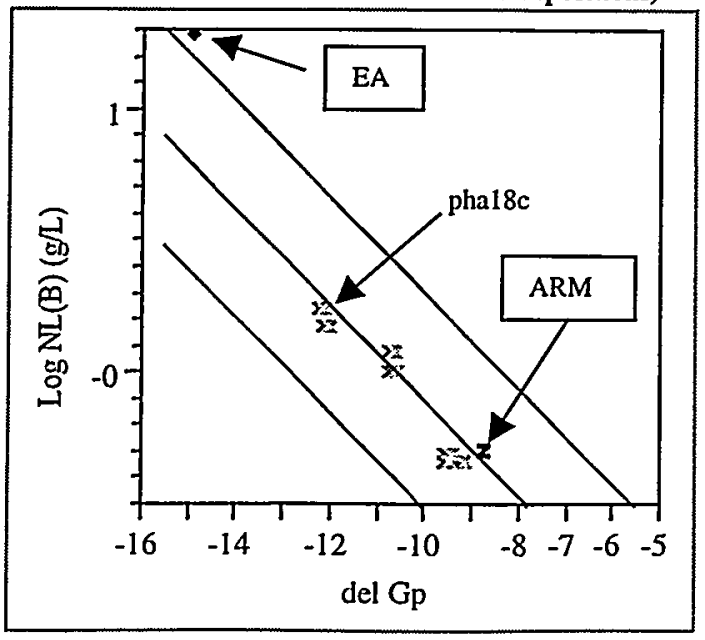

Figure 2.

$\log N L(B)(g / L)$ By del Gp

(Using PHA target compositions \&

EA and ARM reference compositions)

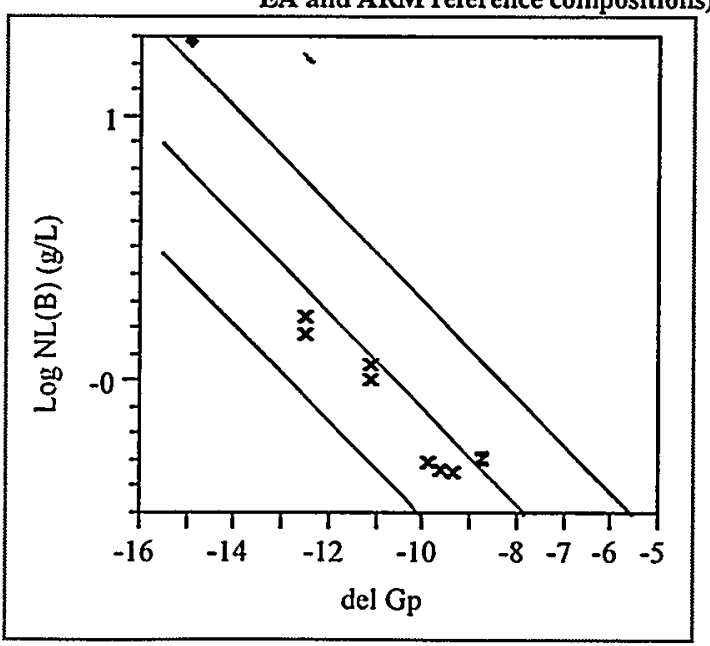


An additional point regarding Figures 1 and 2 should be made, specifically about pha18c. Recall that this composition was a re-batch of an earlier Phase 2 glass. The batched composition of Phase 2 phal 8 missed its original target due to a batching problem. The Phase 4 pha18c hit its target composition, as was noted in the previous section. There was one other feature of pha18 in Phase 2: its PCT result was unpredictable by the DWPF model and unacceptable as compared to DWPF's acceptance region for this property [4]. Glass pha15 of Phase 2 demonstrated the same behavior [4]. The PCT for pha18c of Phase 4 was both predictable and acceptable.

This improvement in the PCT outcome for pha18c prompted a desire to take a re-look at pha15. This glass, pha15, and another Phase 2 glass, pha14, were re-batched; these glasses were designated as pha15c and pha14c. Their chemical compositions were measured and they were subjected to the 7-day PCT. See Appendix B for a discussion of these measurements. The normalized PCTs for these two glasses are provided in Table 9.

Table 9: Normalized PCTs for pha14c and pha15c

\begin{tabular}{|c|c|c|c|c|c|c|c|c|c|}
\hline Glass ID & Composition & $\begin{array}{c}\log N L \\
{[B(g / L)]}\end{array}$ & $\begin{array}{c}\log N L \\
{[\mathrm{Si}(\mathrm{g} / \mathrm{L})]}\end{array}$ & $\begin{array}{c}\log \mathrm{NL} \\
{[\mathrm{Na}(\mathrm{g} / \mathrm{L})]}\end{array}$ & $\begin{array}{c}\log N L \\
{[\mathrm{Li}(\mathrm{g} / \mathrm{L})]}\end{array}$ & $\begin{array}{c}N L \\
B(g / L)\end{array}$ & $\begin{array}{c}\text { NL } \\
S i(g / L)\end{array}$ & $\begin{array}{c}\mathrm{NL} \\
\mathrm{Na}(\mathrm{g} / \mathrm{L})\end{array}$ & $\begin{array}{c}\mathrm{NL} \\
\mathrm{Li}(\mathrm{g} / \mathrm{L})\end{array}$ \\
\hline pha14c & $=$ measured & 0.06317 & -0.25322 & 0.03246 & 0.03802 & 1.16 & 0.56 & 1.08 & 1.09 \\
\hline & target & 0.03885 & -0.26697 & 0.02967 & 0.03252 & 1.09 & 0.54 & 1.07 & 1.08 \\
\hline phal5c & measured & $\begin{array}{l}0.24023 \\
0.21601\end{array}$ & $\begin{array}{l}-0.19416 \\
-0.20994\end{array}$ & $\begin{array}{l}0.17513 \\
0.17687\end{array}$ & 0.18018 & 1.74 & 0.64 & 1.50 & 1.51 \\
\hline
\end{tabular}

Figure 3 provides a plot of the DWPF durability model based upon $\Delta G_{p}$ (showing all nine of the Phase 4 glasses) using measured compositions for the nine glasses. The EA results are indicated with a diamond, the ARM results are indicated by a " $z$ ", and the PHA Phase 2 results by an " $x$ ".

The results of Table 9 and Figure 3 indicate that the PCT for the re-batched pha15c was both predictable and durable, the same improvement as seen for pha18c.

Figure 3: $\log N L(B)(g / L)$ By del Gp

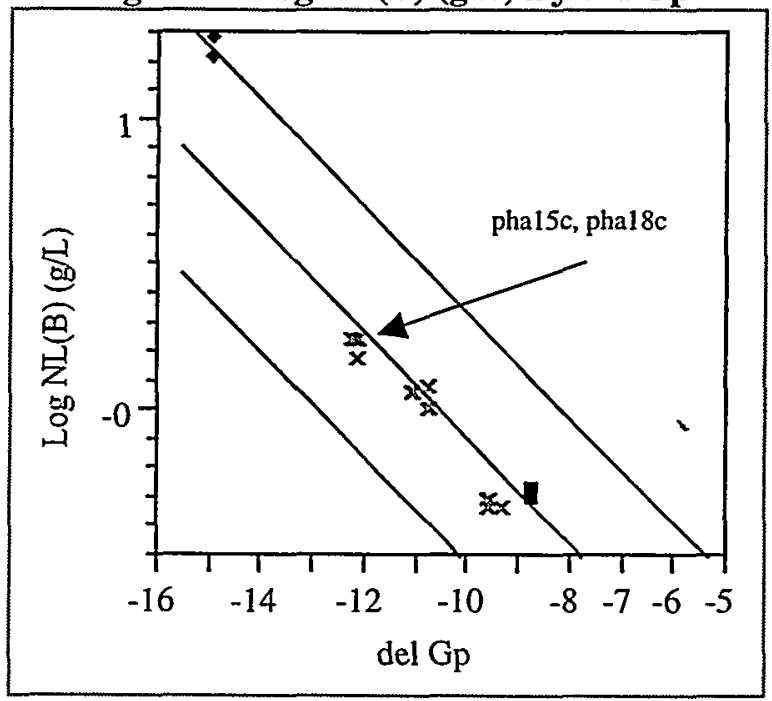

\section{Viscosity at $1150^{\circ} \mathrm{C}$}

Viscosity measurements were made on several of the Phase 4 PHA glasses at SRTC using a Harrop, high-temperature viscometer [12]. The viscosity (in Poise) of each of these glasses at $1150^{\circ} \mathrm{C}$ was estimated from a Fulcher equation fitted to a set of viscosity measurements taken over an appropriate 
range of temperatures. The functional form of the (three-parameter) Fulcher equation (expressed in Poise) used to fit these data is given by equation (1):

$$
\ln \hat{\eta}=A+\frac{B}{(T-C)}
$$

where $A, B$, and $C$ represent the parameters of the model that were determined from the available measurements (represented by $\eta$, expressed in Poise) at various temperatures (represented by $T$ ). The fitted model was then used to predict the viscosity of the given glass at $1150^{\circ} \mathrm{C}$.

Although no definitive error analysis has been completed on the use of the Harrop viscometer, SRTC has conducted sevveral sets of viscosity measurements using this viscometer with good results [13]. Two crucible/spindle sets were used in conducting these measurements, which were sequenced according to the plan provided in Attachment IV of [9]. This plan covered the CST and PHA Phase 4 glasses and called for measurements of several of the PHA glasses to be followed by measurements of the Batch 1 standard glass with both crucible/spindle sets. Measurements of Batch 1 conducted before the planned measurements were reported in [13] and [3]. Exhibit A.8 of Appendix A provides the measured viscosities, the results of the Fulcher fit, and the prediction at $1150^{\circ} \mathrm{C}$ for each of the PHA Phase 4 glasses that were tested. The details of the measurements of the final two samples of Batch 1 were presented in [7]. The information presented in this exhibit (along with predictions from the DWPF viscosity model and the Batch 1 results from [3], [10] and [7]) is summarized in Table 10.

Table 10: Viscosity Results (in Poise) By Glass $\mathrm{D}$

\begin{tabular}{|c|c|c|c|c|}
\hline Glass ID & $\begin{array}{c}\text { Viscosity } \\
\text { (Poise) } \\
@ 1150^{\circ} \mathrm{C}\end{array}$ & $\begin{array}{c}\text { Predicted } \\
\text { (measured } \\
\text { composition) }\end{array}$ & $\begin{array}{c}\text { Predicted } \\
\text { (bias-corrected } \\
\text { composition) }\end{array}$ & $\begin{array}{c}\text { Predicted } \\
\text { (target } \\
\text { composition) }\end{array}$ \\
\hline Batch 1 & $\begin{array}{c}48.6,49.7,46.4 \\
48.9,47.3\end{array}$ & $\begin{array}{c}44.2 \\
\text { (Sharp-Schurtz) }^{3}\end{array}$ & & 56.2 \\
\hline pha11c & Not Measured & 45.6 & 51.2 & 40.4 \\
\hline pha12c & 27.6 & 32.7 & 36.7 & 28.5 \\
\hline pha17c & Not Measured & 32.7 & 37.1 & 31.3 \\
\hline pha18c & Not Measured & 21.7 & 24.8 & 21.3 \\
\hline pha20 & Not Measured & 96.7 & 105.8 & 102.0 \\
\hline pha26 & Not Measured & 98.4 & 106.3 & 97.0 \\
\hline pha32 & 89.7 & 90.4 & 99.5 & 91.9 \\
\hline pha14c & Not Measured & 31.4 & N/A & 33.3 \\
\hline pha15c & 22.8 & 22.0 & N/A & 23.0 \\
\hline Batch 1 & $49.9,49.5$ & 44.2 & & 56.2 \\
\hline & & (Sharp-Schurtz) & $=$ & \\
\hline
\end{tabular}

The melt viscosities at $1150^{\circ} \mathrm{C}$ for the three PHA glasses (pha12c, pha15c, and pha32) are within the DWPF operating range. However, the HM glass with $10 \mathrm{wt} \%$ PHA (pha32) had a measured viscosity of 90 poise which is close to the upper limit for DWPF operations. Predictions indicate that decreasing the PHA to $7 \mathrm{wt} \%$ (pha31) would increase the viscosity to 120 poise while increasing the PHA to $13 \mathrm{wt} \%$ (pha33) would decrease the viscosity to 69 poise. Since the model prediction for pha32 is very close to the measured viscosity, the expectation is that lower levels of PHA would lead to glasses with viscosities too high for operations at DWPF. On the other hand, at higher levels of PHA, the viscosities drop to levels comfortably within the operating range.

For the Purex glasses, pha12c and pha15c, the measured viscosities of 28 and 23 poise, respectively, indicate that DWPF processing may be compromised at the low end of the viscosity range (20 poise). Further work will be required to resolve this issue. 


\section{Liquidus Temperature $\left(\mathbf{T}_{\mathrm{L}}\right)$}

The standard ASTM practice for measuring liquidus temperature uses a gradient furnace. The equipment for determining liquidus temperature by this method is being installed and tested within SRTC in a clean laboratory. Due to the presence of depleted uranium in the glass samples (as well as the early stage of equipment setup), we were not able to use this method for liquidus determination. A decision was therefore made to perform isothermal holds using reasonable quanitities of the glass to bound the liquidus temperature.

$\mathrm{XRD}$ was selected as the method of detection for crystal formation in the glasses. It is estimated that the sensitivity of XRD (non-quantitative) is $\sim 0.7$ to $1 \mathrm{wt} \%$ for a crystalline phase (in this case, Trevorite). Therefore, for this type of measurement, absence of detection of a crystalline phase was evidence that the liquidus temperature is less than the temperature of that isothermal hold. On the other hand, detection of Trevorite (or any other primary crystalline phase) indicates that the liquidus temperature is higher than the temperature of the isothermal hold.

The liquidus temperature for each glass composition was estimated by performing an isothermal hold starting a a $900^{\circ} \mathrm{C}$ and increasing in $50^{\circ} \mathrm{C}$ increments as required. Approximately 5 grams of each glass were placed in small platinum crucibles and transferred to a furnace already heated to $1150^{\circ} \mathrm{C}$. After a four-hour hold period, the temperature was reduced to the desired temperature and held at that temperature for 24 hours. The crucibles were then removed from the furnace and the glass allowed to cool within the crucibles at room temperature. The PHA glasses at the hold temperature were submitted for XRD analysis. Care was taken to obtain glass that was not part of the top glass surface. The glass pieces, although mainly from the bulk, usually included part of the bottom surface (i.e., that surface in contact with the crucible). Those glasses containing Trevorite in the bulk glass were then taken to higher temperatures and analyzed by XRD. The approximate, bounding liquidus temperatures for the 9 PHA glasses were as given in Table 11.

Table 11: Liquidus Temperatures

\begin{tabular}{|c|c|c|c|c|}
\hline Glass & Liquidus & \multicolumn{3}{|c|}{$\mathrm{T}_{\mathrm{L}}$ Prediction Using Glass Composition as Represented by } \\
\hline ID & Temperature & Target & Measured & Measured bias-cor. \\
\hline pha11c & $<900^{\circ} \mathrm{C}$ & 1001.5 & 987.3 & 977.5 \\
\hline pha12c & $<900^{\circ} \mathrm{C}$ & 1012.2 & 997.5 & 987.1 \\
\hline pha17c & $<1000^{\circ} \mathrm{C}$ & 1051.0 & 1050.9 & 1037.6 \\
\hline pha18c & $<950^{\circ} \mathrm{C}$ & 1065.7 & 1073.8 & 1059.2 \\
\hline pha20 & $<900^{\circ} \mathrm{C}$ & 906.3 & 916.2 & 910.2 \\
\hline pha26 & $<900^{\circ} \mathrm{C}$ & 935.6 & 928.3 & 922.3 \\
\hline pha32 & $<900^{\circ} \mathrm{C}$ & 970.7 & 959.2 & 950.8 \\
\hline pha14c & $<1000^{\circ} \mathrm{C}$ & 1045.4 & 1059.8 & N/A \\
\hline pha15c & $<1000^{\circ} \mathrm{C}$ & 1059.3 & 1073.9 & N/A \\
\hline
\end{tabular}

The bounding liquidus temperatures are below the nominal PAR value of $1025^{\circ} \mathrm{C}$ [14]. Given the fact that liquidus temperatures were only approximated, the $30 \mathrm{wt} \%$ loading of Purex may be near or at the edge of acceptability for liquidus. The predictions based upon measured, bias-corrected, and target compositions from DWPF's liquidus model are also provided in Table 11 . The model predicts unacceptable liquidus temperatures for the glasses at $30 \mathrm{wt} \%$ Purex (i.e., pha14c, pha15c, pha17c, and pha18c).

\section{Surface Crystallization}

For liquidus measurements, crystal formation is considered only in the interior or bulk glass region. Therefore, samples submitted for XRD analysis were bulk samples. However, crystals can form at the interface of the glass and the crucible and/or the glass and air. For completeness, the detection of these

4 No opportunity for bias correction was available for these glasses. Not enough standards were in the analytical runs for these glasses. 
surface crystals on the top of the glass is provided in Table 12 as a function of temperature. The crystals detected in the PHA glasses were located at the center of the top glass surface.

Table 12. Surface Crystals for the Nine PHA Glasses as a Function of Temperature ----after the 24 hour heat treatment--.-

\begin{tabular}{|c|c|c|c|c|c|c|c|c|c|}
\hline & pha11c & pha12c & pha14c & pha15c & pha17c & pha18c & pha20 & pha26 & pha32 \\
\hline $1150^{\circ} \mathrm{C}$ & No test & No test & No test & No test & No test & No test & No test & No të́st & No test \\
\hline $1000^{\circ} \mathrm{C}$ & No test & No test & none & none & none & No test & No test & No test & No test \\
\hline $950^{\circ} \mathrm{C}$ & No test & No test & none & No test & none & No test & No test & No test & No test \\
\hline $900^{\circ} \mathrm{C}$ & none & none & crystals & crystals & crystals & crystals & none & none & none \\
\hline
\end{tabular}

This composition of the surface crystals determined using EDS is consistent with the Trevorite $\left(\mathrm{NiFe}_{2} \mathrm{O}_{4}\right)$ crystal structure and in agreement with crystals identified during previous studies on these types of systems. The chemical composition indicates that other cations are substituted into the crystal structure in small amounts and these include $\mathrm{Ti}, \mathrm{Cr}$, and $\mathrm{Mn}$.

\section{Phase Separation}

The formation of separate amorphous phases in glass is referred to as amorphous phase separation or inhomogeneity. Crystal formation, as determined by liquidus measurements on the other hand, is also a type of phase separation, but reflects crystalline particles within the glass matrix. Amorphous phase separation is to be avoided since the models currently used to predict durability do not apply for glasses predicted to be phase separated. The property acceptance region (PAR) limit for the homogeneity constraint in the PCCS is nominally a value of 211 [14]. For the measurement acceptance region (MAR), the value will be even higher. In order to pass this constraint, the calculated value must be greater than the MAR value. The homogeneity values calculated using the measured chemical compositions reveal that all of the HM glasses and two of the Purex glasses are below the PAR value. These values are provided in Table 13.

Table 13: Homogeneity Property Predictions

\begin{tabular}{|c|c|c|c|}
\hline & \multicolumn{3}{|c|}{$\begin{array}{c}\text { Homogeneity Property Prediction } \\
\text { (Acceptability Requires a Value >211) }\end{array}$} \\
\hline & $\begin{array}{c}\text { Target } \\
\text { Composition }\end{array}$ & $\begin{array}{c}\text { Measured } \\
\text { Composition }\end{array}$ & $\begin{array}{c}\text { Bias-Corrected } \\
\text { Composition }\end{array}$ \\
\hline Glass ID & 205.8 & 203.7 & 200.5 \\
\hline pha11c & 205.4 & 205.2 & 202.0 \\
\hline pha12c & 213.5 & 211.1 & 207.1 \\
\hline pha17c & 213.2 & 218.9 & 214.8 \\
\hline pha18c & 201.1 & 199.2 & 197.4 \\
\hline pha20 & 209.1 & 206.0 & 203.5 \\
\hline pha26 & 217.1 & 208.8 & 206.6 \\
\hline pha32 & 215.3 & 214.5 & N/A \\
\hline pha14c & 214.9 & 215.6 & N/A \\
\hline pha15c & & & \\
\hline
\end{tabular}

The homogeneity constraint was developed for glasses that do contain PHA. Therefore, the predictability of phase separation by this model should be applicable. A significant search for phase separation in these glasses is beyond the scope of work for this task, except when routine SEM analysis is performed. For these six glasses, no SEM analyses were performed. 


\section{CONCLUSIONS}

The results presented in this report are for nine PHA Phase 4 glasses. Three of the glasses contained HM sludge at 22, 26, and $30 \mathrm{wt} \%$ respectively, $10 \mathrm{wt} \%$ PHA and $1.25 \mathrm{wt} \% \mathrm{MST}$, all on an oxide basis. The remaining six glasses were selected from the Phase 1 and Phase 2 studies (Purex sludge) but with an increased amount of MST. The high-end target for MST of $2.5 \mathrm{wt} \%$ oxide was missed in Phases 1 and 2 due to $\sim 30$ wt\% water content of the MST. A goal of this Phase 4 stüdy was to determine whether this increase in titanium concentration from the MST had any impact on glass quality or processibility. Two of the glasses, pha14c and pha15c, were rebatched and melted due to apparent batching errors with pha14 and pha15.

The models currently in DWPF's PCCS were used to predict durability, homogeneity, liquidus, and viscosity for these nine glasses. All of the HM glasses and half of the Purex glasses were predicted to be phase separated, and consequently prediction of glass durability is precluded with the current models for those glasses that failed the homogeneity constraint. If one may ignore the homogeneity constraint, the measured durabilities were within the $95 \%$ prediction limits of the model. Further efforts will be required to resolve this issue on phase separation (inhomogeneity).

The liquidus model predicted unacceptable liquidus temperatures for four of the nine glasses. The approximate, bounding liquidus temperatures measured for all had upper limits of $1000^{\circ} \mathrm{C}$ or less. Given the fact that liquidus temperatures were only approximated, the $30 \mathrm{wt} \%$ loading of Purex may be near or at the edge of acceptability for liquidus.

The measured viscosities were close to the predictions of the model. For the Purex glasses, pha12c and pha15c, the measured viscosities of 28 and 23 poise, respectively, indicate that DWPF processing may be compromised at the low end of the viscosity range ( 20 poise). Although the HM sludge glass examined (10 wt $\%$ PHA) had a measured viscosity of $\sim 90$ poise, the HM glasses at $7 \mathrm{wt} \%$ PHA are predicted to be higher than the 100 poise limit for DWPF. Further work will be required to resolve these issues.

\section{REFERENCES}

[1] Elder, H. H., "Technical Task Request: DWPF Waste Qualification - DWPF Coupled Operation Chemistry," HLW-SDT-TTR-99-07.0, February 2, 1999.

[2] Harbour, J. R. and T. B. Edwards, "Technical Task and QA Plan: DWPF Coupled Operation Chemistry - PHA Glass Testing," WSRC-RP-99-00218, Revision 1, April 23, 1999.

[3] Edwards, T. B., J. R. Harbour, and R. J. Workman, "Composition and Property Measurements for PHA Phase 1 Glasses (U)," WSRC-TR-99-00262, Revision 0, August 4, 1999.

[4] Edwards, T. B., J. R. Harbour, and R. J. Workman, "Composition and Property Measurements for PHA Phase 2 Glasses (U)," WSRC-TR-99-00290, Revision 0, August 18, 1999.

[5] Edwards, T. B., J. R. Harbour, and R. J. Workman, "Composition and Property Measurements for PHA Phase 3 Glasses (U)," WSRC-TR-99-00292, Revision 0, August 18, 1999.

[6] ASTM C1285-97, "Standard Test Methods for Determining Chemical Durability of Nuclear Waste Glasses: The Product Consistency Test (PCT)," 1997.

[7] Edwards, T. B., J. R. Harbour, and R. J. Workman, “Composition and Property Measurements for CST Phase 4 Glasses (U)," WSRC-TR-99-00293, Revision 0, August 18, 1999.

[8] Edwards, T. B., J. R. Harbour, and R. J. Workman, "Composition and Property Measurements for CST Phase 3 Glasses (U)," WSRC-TR-99-00291, Revision 0, August 18, 1999. 
[9] Edwards, T. B., J. R. Harbour, and R. J. Workman, "Composition and Property Measurements for CST Phase 2 Glasses (U)," WSRC-TR-99-00289, Revision 0, August 18, 1999.

[10] Harbour, J. R. and T. B. Edwards, "Analytical Study Plan-PHA: DWPF Coupled Operation Chemistry - PHA Glass Testing," WSRC-RP-99-00315, Revision 0, April 14, 1999.

[11] Jantzen, C. M., J. B. Pickett, K. G. Brown, T. B. Edwards, and D. C. Beäm, "Process/Product Models for the Defense Waste Processing Facility (DWPF): Part I. Predicting Glass Durability from Composition Using a Thermodynamic Hydration Energy Reaction Model (THERMO) (U)," WSRC-TR-93-672, Rev. 1, September 28, 1995.

[12] Schumacher, R. F. and D. K. Peeler, "Establishment of Harrop, High-Temperature Viscometer," WSRC-RP-98-00737, Revision 0, September 1998.

[13] Schumacher, R. F., R. J. Workman, J. R. Harbour, and T. B. Edwards, "Measurements of DWPF Glass Viscosity - Interim Report," WSRC-RP-99-00350, Revision 0, May 5, 1999.

[14] . Brown, K. G. and R. L. Postles, "SME Acceptability Determination for DWPF Process Control (U)," WSRC-TR-95-0364, Revision.3, February 21, 1996. 
WSRC-TR-99-00294

Revision 0

This page intentionally left blank. 


\section{Appendix A:}

\section{Supplemental Tables and Exhibits}

$x$ 
WSRC-TR-99-00294

Revision 0

This page intentionally left blank. 
Table A.1: Composition Measurements Using Peroxide Fusion Dissolutions (expressed as cation weight fractions)

\begin{tabular}{|c|c|c|c|c|c|c|c|}
\hline Glass ID & Block & Seq & LIMS\# & Lab ID & B & $\mathrm{Ca}$ & $\mathrm{Si}$ \\
\hline Batch I & 1 & 1 & $130865 a$ & NA2O2 - Batch 1 std 1 & 0.02373 & 0.01109 & 0.23817 \\
\hline phal7c & 1 & 3 & $130839 \mathrm{a}$ & NA2O2 - F14pf1 & 0.02288 & 0.00976 & 0.20299 \\
\hline pha18c & 1 & 4 & $130853 a$ & NA2O2 - F09pf1 & 0.02723 & 0.01004 & 0.20124 \\
\hline pha18c & 1 & 6 & $130854 a$ & $\mathrm{NA2O2}-\mathrm{FO9pR2}$ & 0.02780 & 0.00988 & 0.20499 \\
\hline pha20 & 1 & 7 & $130862 \mathrm{a}$ & $\mathrm{NA}_{2} \mathrm{O}_{2}$ - $\mathrm{F}_{10 \mathrm{p} 2}$ & 0.02664 & 0.00394 & 0.25885 \\
\hline Ustd & I & 9 & $130868 \mathrm{a}$ & NA2O2 - U std - 1 & 0.03186 & 0.01313 & 0.25186 \\
\hline pha26 & 1 & 12 & $130841 \mathrm{a}$ & $\mathrm{NA2O2}-\mathrm{F}_{2} 2 \mathrm{pf} 2$ & 0.02611 & 0.00536 & 0.25223 \\
\hline pha32 & 1 & 13 & $130847 \mathrm{a}$ & NA2O2 - F05pfl & 0.02469 & 0.00551 & 0.23859 \\
\hline pha20 & 1 & 15 & $130845 a$ & NA2O2 - F10pf1 & 0.02657 & 0.00449 & 0.25647 \\
\hline Batch 1 & 1 & 17 & $130866 \mathrm{a}$ & $\mathrm{NA} 2 \mathrm{O} 2$ - Batch 1 std 2 & 0.02396 & 0.01199 & 0.23984 \\
\hline phallc & 1 & 19 & $130848 \mathrm{a}$ & $\mathrm{NA2O2}-\mathrm{F08pf1}$ & 0.02563 & 0.00825 & 0.23199 \\
\hline phal2c & $I$ & 21 & $130863 a$ & NA2O2 - F12pf2 & 0.02922 & 0.00927 & 0.22949 \\
\hline pha12c & 1 & 22 & $130863 a$ & $\mathrm{NA2O2}-\mathrm{Fl2pf2}$ & 0.02922 & 0.00927 & 0.22949 \\
\hline pha17c & 1 & 23 & $130855 \mathrm{a}$ & $\mathrm{NA2O2}$ - F14pf2 & 0.02413 & 0.01005 & 0.21383 \\
\hline Ustd & 1 & 25 & $130869 a$ & NA2O2 - U std-2 & 0.03035 & 0.01038 & 0.23328 \\
\hline pha32 & $I$ & 27 & $130860 \mathrm{a}$ & $\mathrm{NA2O2}-\mathrm{FOSpf2}$ & 0.02411 & 0.00552 & 0.23136 \\
\hline pha26 & $I$ & 31 & $130840 \mathrm{a}$ & $\mathrm{NA2O2}-\mathrm{FO} 2 \mathrm{pfl}$ & 0.02469 & 0.00469 & 0.23931 \\
\hline phal Ic & 1 & 32 & $130858 \mathrm{a}$ & NA2O2 - F08pf2 & 0.02610 & 0.00867 & 0.23482 \\
\hline Batch 1 & 1 & 33 & $130867 \mathrm{a}$ & NA2O2 - Batch 1 std 3 & 0.02349 & 0.01167 & 0.23586 \\
\hline Batch 1 & 2 & 1 & $130865 b$ & NA2O2 - BATCH I STD-1 & 0.02467 & 0.01076 & 0.24624 \\
\hline pha26 & 2 & 5 & $130841 \mathrm{~b}$ & $\mathrm{NA} 2 \mathrm{O} 2-\mathrm{FO}_{2} \mathrm{pf}$ & 0.02719 & 0.00511 & 0.26373 \\
\hline Ustd & 2 & 9 & $130868 \mathrm{~b}$ & NA2O2 - U std-1 & 0.03198 & 0.01369 & 0.25368 \\
\hline pha1 1c & 2 & 10 & $130848 b$ & NA2O2 - F08pf1 & 0.02646 & 0.00834 & 0.23996 \\
\hline pha20 & 2 & 11 & $130862 \mathrm{~b}$ & NA2O2-F10pf2 & 0.02725 & 0.00407 & 0.26503 \\
\hline phalle & 2 & 12 & $130858 \mathrm{~b}$ & $\mathrm{NA2O2}-\mathrm{FO} \mathrm{Bph}$ & 0.02642 & 0.00865 & 0.23999 \\
\hline pha20 & 2 & 14 & $130845 \mathrm{~b}$ & NA2O2-F10pf1 & 0.02741 & 0.00592 & 0.26616 \\
\hline pha26 & 2 & 16 & $130840 \mathrm{~b}$ & $\mathrm{NA2O} 2-\mathrm{FO} 2 \mathrm{pfl}$ & 0.02593 & 0.00526 & 0.25254 \\
\hline Batch 1 & 2 & 17 & $130866 \mathrm{~b}$ & NA2O2 - Batch 1 std-2 & 0.02396 & 0.01125 & 0.24023 \\
\hline phal $8 c$ & 2 & 19 & $130854 \mathrm{~b}$ & NA2O2 - F09pf2 & 0.02832 & 0.01029 & 0.20940 \\
\hline pha18c & 2 & 20 & $130853 b$ & $\mathrm{NA2O2}-\mathrm{F09pfl}$ & 0.02843 & 0.01049 & 0.21038 \\
\hline phal 7c & 2 & 22 & $130855 \mathrm{~b}$ & NA2O2 - F14pf2 & 0.02507 & 0.00989 & 0.22353 \\
\hline pha32 & 2 & 23 & $130860 \mathrm{~b}$ & NA2O2 - F05pf2 & 0.02506 & 0.00548 & 0.24274 \\
\hline Ustd & 2 & 25 & $130869 \mathrm{~b}$ & NA2O2 - U std-2 & 0.02975 & 0.01128 & 0.22782 \\
\hline pha32 & 2 & 26 & $130847 \mathrm{~b}$ & NA2O2 - F05pf1 & 0.02546 & 0.00619 & 0.24724 \\
\hline phal7c & 2 & 27 & $130839 b$ & NA2O2 - F14pf1 & 0.02436 & 0.00999 & 0.21797 \\
\hline pha12c & 2 & 31 & $130863 b$ & $\mathrm{NA2O}-\mathrm{F} 12 \mathrm{pf} 2$ & 0.02815 & 0.00912 & 0.22712 \\
\hline pha12c & 2 & 32 & $130852 b$ & $\mathrm{NA2O2}-\mathrm{F} 12 \mathrm{pfl}$ & 0.02873 & 0.00843 & 0.22811 \\
\hline Batch 1 & 2 & 33 & $130867 \mathrm{~b}$ & NA2O2 - Batch 1 std-3 & 0.02497 & 0.01203 & 0.25302 \\
\hline
\end{tabular}

Values at their detection limits were set to their detection limits.

The CST Phase 4 glasses were analyzed with these PHA glasses. Their values are not presented here. See [8] for a complete listing which includes the CST glasses. 
Table A.2: Composition Measurements From Microwave Preparation (expressed as cation weight fractions)

\begin{tabular}{|c|c|c|c|c|c|c|c|c|c|c|c|c|c|c|c|c|c|c|c|c|}
\hline \multirow{2}{*}{$\begin{array}{l}\text { Glass } \\
\text { ID } \\
\end{array}$} & \multirow[b]{2}{*}{ Block } & \multirow[b]{2}{*}{ Seq } & \multirow[b]{2}{*}{ LIMS \# } & & \multirow{2}{*}{\multicolumn{9}{|c|}{$\frac{\text { n weight fractions }}{\text { ICP.ES }}$}} & & & & & & & \\
\hline & & & & & & $\pi$ & & $C_{u}$ & Fe & & & & & & & & & & & $A A^{5}$ \\
\hline Batch 1 & 1 & 1 & $130803 a$ & MW - BATCH I STD 1 & 0.02572 & 0.00879 & 0,00074 & 0.00318 & $\frac{F c}{0.09252}$ & $\frac{21}{002105}$ & $\mathrm{Mg}$ & $\mathrm{Mn}$ & $\mathrm{Na}$ & $\mathrm{Nb}$ & $\mathrm{Ni}$ & S) & TI & $\mathbf{U}$ & $\mathbf{Z r}$ & $\mathrm{K}$ \\
\hline pha18c & 1 & 4 & $130800 \mathrm{a}$ & $\mathrm{MW}-\mathrm{F} 09 \mathrm{mw} 2$ & 0.01893 & 0.00957 & $\begin{array}{l}0.00014 \\
0.00127\end{array}$ & $\frac{0.00370}{0.00878}$ & $\frac{0.09252}{0.09968}$ & $\frac{0.02105}{0.01852}$ & 0.00861 & 0.01336 & 0.06798 & 0.00048 & 0.00615 & 0.21578 & 0.00417 & 0.00280 & 0.00118 & 0.02592 \\
\hline pha20 & 1 & 5 & $130798 a$ & $\mathrm{MW}-\mathrm{F} 10 \mathrm{~mW} 2$ & 0.02836 & 0.00325 & 0.00077 & 0.00566 & $\frac{0.09968}{0.04860}$ & $\frac{0.01852}{0.02134}$ & 0.00751 & 0.02075 & 0.06882 & 0.00054 & 0.00967 & 0.19823 & 0.01416 & 0.01830 & 0.00141 & \\
\hline phan26 & I & 6 & $130781 \mathrm{a}$ & $\mathrm{MW}-\mathrm{F} 02 \mathrm{mw} 2$ & 0.03413 & 0.00365 & $\frac{.000}{0.00084}$ & 0.00551 & 0.05134 & $\frac{0.02134}{0.02028}$ & 0.00698 & 0.01574 & 0.05468 & 0.00053 & 0.00271 & 0.23294 & 0.00691 & 0.00802 & 0.00117 & $\frac{0.04350}{.03524}$ \\
\hline phal $8 \mathrm{c}$ & $I$ & 8 & $130786 a$ & MW - F09mw1 & 0.01773 & 0.00906 & 0.00120 & 0.00846 & \begin{tabular}{|c|}
0.02134 \\
0.09557
\end{tabular} & $\frac{0.02028}{0.01774}$ & 0.00773 & 0.01803 & 0.05887 & 0.00050 & 0.00300 & 0.22782 & 0.00703 & 0.00912 & & 0.03565 \\
\hline Ustd & 1 & 2 & $130806 a$ & MW - U STD-1 & 0.02131 & 0.00936 & 0.00181 & 0.00011 & 0.09711 & $\frac{0.01774}{0.01460}$ & 0.00698 & 0.01990 & 0.06548 & 0.00052 & 0.00925 & 0.18943 & 0.01362 & 0.01939 & 0.00131 & $\frac{0.02503}{0.04283}$ \\
\hline pha.32 & 1 & 11 & $130792 \mathrm{a}$ & MW.F05mwl & 0.03832 & 0.00436 & 0.00089 & 0.00634 & 0.05818 & $\begin{array}{l}0.01460 \\
0.01905\end{array}$ & $\frac{0.00725}{0.00681}$ & $\frac{0.02188}{0.02139}$ & 0.08988 & 0.00052 & 0.00876 & 0.20346 & & & & 0.02324 \\
\hline pha26 & 1 & 14 & $130775 a$ & $\mathrm{MW} \cdot \mathrm{F} 02 \mathrm{mwl}$ & 0.01467 & 0.00712 & 0.00112 & 0.00634 & 0.07076 & $\frac{0.01905}{0.02253}$ & $\frac{0.00681}{0.00868}$ & 0.02139 & 0.05998 & 0.00053 & 0.00346 & 0.21810 & 0.00 & 0.00742 & 0.00141 & $\frac{0.02344}{0.03477}$ \\
\hline phal 2c & 1 & 15 & $130782 a$ & $M W-F 12 m w 2$ & 0.01379 & 0.00738 & 0.00100 & 0.00789 & 0.07854 & 0.01981 & $\frac{0.00868}{0.00716}$ & $\frac{0.01575}{0.01530}$ & 0.06201 & 0.00052 & 0.00724 & 0.23196 & 0.00730 & & & $\frac{0.03518}{0.035}$ \\
\hline Batch 1 & 1 & 17 & $130804 a$ & MW - Batch I Std-2 & 0.02610 & 0.00909 & 0.00072 & $\frac{0.0170}{0.00326}$ & 0.09527 & 0.02171 & $\frac{0.00 / 10}{0.00887}$ & $\frac{0.01530}{0.01370}$ & 0.06235 & 0.00048 & & 0.20602 & 0.01327 & 983 & 0.00111 & 0.04284 \\
\hline pha.32 & $T$ & 19 & $130801 \mathrm{a}$ & MW - F05mw2 & 0.03696 & 0.00422 & 0.00084 & 0.00629 & 0.05769 & & $\frac{0.00887}{0.00652}$ & $\frac{0.01370}{0.02114}$ & 0.06977 & 0.00048 & 0.00618 & 0.22852 & 0.00 & & & 0.02319 \\
\hline pha20 & 1 & 20 & $130780 \mathrm{a}$ & MW-FlOmwl & 0.02949 & 0.00339 & 0.00079 & 0.00562 & 0,04902 & 0.02123 & 0.00753 & $\frac{0.02114}{0.01572}$ & 0.05938 & 0.00054 & & 0.21782 & 0.00694 & 0.0 & 0.00162 & 0.03460 \\
\hline phalle & 1 & 21 & $130787 \mathrm{a}$ & MW - F08mw2 & 0.01465 & 0.00744 & 0.00107 & 0.00605 & 0.07832 & 0.02048 & $\frac{0.00778}{0.0078}$ & $\frac{0.01572}{0.01610}$ & 0.05678 & 0.00050 & 0.00266 & 0.23737 & 0.00682 & & & 0.03477 \\
\hline pha12c & 1 & 22 & $130779 \mathrm{a}$ & $\mathrm{MW}-\mathrm{Fl} 2 \mathrm{mwl}$ & 0.01478 & 0.00771 & 0.00100 & 0.00791 & 0.08007 & 0.01987 & 0.00787 & & 0.06104 & 0.00052 & 0.00768 & 0.21885 & & 339 & 0.00130 & 0.03262 \\
\hline phalle & 1 & 24 & $130784 a$ & - F08mwI & 0.01463 & 0.00750 & 0.00106 & 0.00594 & 0.07736 & 0.02026 & & 0.01545 & 0.06381 & 0.00053 & 0.00770 & 0.21211 & 0.01333 & & 0114 & 0.04347 \\
\hline Ustd & 1 & 25 & $130807 a$ & MW-U SId-2 & 0.02104 & 0.00935 & 0.00176 & $\frac{0.00394}{0.00010}$ & $\frac{0.07130}{0.09645}$ & $\frac{0.02026}{0.01451}$ & $\frac{0.00776}{0.00719}$ & 0.01582 & 0.06170 & 0.00053 & 0.00750 & 0.21780 & 314 & 0.01644 & 0.00125 & 0.03245 \\
\hline phal $7 \mathrm{c}$ & $T$ & 28 & 1307 & - Fl4mwl & 0.01526 & 0.00773 & 0.00125 & 0.00620 & 0.09406 & $\frac{0.01431}{0.01863}$ & $\frac{0.00 / 19}{0.00615}$ & 0.02163 & 0.08938 & 0.00050 & 0.00 & 0.20290 & 0.00605 & 0.01 & & 0.02346 \\
\hline$a 17 c$ & 1 & 31 & 1308 & MW - F14mw2 & 0.01713 & 0.008 & 0,00124 & 0.00614 & $\frac{0.09400}{0.09449}$ & $\frac{0.01803}{0.01868}$ & $\frac{0.00015}{0.00701}$ & 0.02055 & 0.05856 & 0.00050 & 0.00949 & 0.20195 & & & 0.00132 & 0.03637 \\
\hline Batch 1 & 1 & 33 & 1308 & MW - Barch I Std-3 & 0.02523 & 0.00871 & 0.00070 & 0.00315 & 0.09305 & 0.02107 & $\frac{0.00701}{0.00861}$ & 0.02070 & 0.06309 & 0.00051 & 0.00 & & & & & 0.03658 \\
\hline & 2 & 1 & 1308 & MW - BATCH I STD-1 & 0.02594 & 0.00885 & 0.00074 & $\frac{0.00322}{0.0032}$ & D.0950312 & $\frac{0.02101}{0.02140}$ & 0.00861 & 0.01330 & 0.06751 & 0.00051 & 0.00605 & 0.22517 & & & & 0.02566 \\
\hline $117 c$ & 2 & 3 & 13080 & $\mathrm{MW}-\mathrm{F} 14 \mathrm{~mW} 2$ & 0.01717 & 0.00871 & 0.00125 & 0.00616 & 0.09447 & \begin{tabular}{|c|c|}
0.01877 \\
0.0187
\end{tabular} & $\frac{0.00873}{0.00701}$ & $\frac{0.01346}{0.02069}$ & 0.06887 & 0.00048 & 0.00 & 0.21817 & 0.00421 & & & 0.02710 \\
\hline $\mathrm{nllc}$ & 2 & 4 & & MW - F08mw1 & 0.01496 & 0.00758 & 0.00107 & 0.00602 & 0.07818 & 0.02048 & 0.00781 & 0.02069 & 0.06325 & 0.00051 & & 0.11 & & & & 0.03789 \\
\hline $12 c$ & 2 & 5 & 13078 & $n w 2$ & 0.01373 & 0.00741 & 0.00099 & 0.00792 & 0.07897 & 0.01988 & 0.00720 & $\frac{0.01601}{0.01530}$ & 0.06248 & 0.00053 & & & & & & 0.03338 \\
\hline pha/8c & 2 & 6 & $130800 \mathrm{~b}$ & MW-F09mw2 & 0.01892 & 0.00964 & 0.00125 & 0.00888 & 0.10065 & 0.01875 & $\frac{0.00720}{0.00758}$ & 0.01530 & 0.06232 & 0.00048 & 0.00 & & 0.01 & & & 0.04544 \\
\hline phallec & 2 & 7 & $130787 \mathrm{~b}$ & & 0.01467 & 0.00747 & 0.00106 & 0.00607 & 0.07869 & 0.02059 & $\frac{0.00780}{0.00782}$ & 0.02075 & 0.06922 & 0.00054 & 0.009 & & & 0.01 & & 0.04762 \\
\hline phan26 & 2 & 8 & $130781 \mathrm{~b}$ & F02mw2 & 0.03417 & 0.00369 & 0.00080 & 0.00553 & 0.05144 & $\frac{0.02059}{0.02051}$ & $\frac{0.00782}{0.00778}$ & 0.01611 & 0.06138 & 0.00052 & 0.00 & & 0.0 & & & 0.03798 \\
\hline Usid & 2 & 9 & 1308 & & 0.02116 & 0.00935 & 0.00176 & 0.00009 & 0.09698 & 0.01460 & $\frac{0.00778}{0.00725}$ & $\frac{0.01791}{0.02168}$ & 0.05911 & 0.00 & 0.00 & & 0.00 & 0.00706 & & 0.03814 \\
\hline 1.32 & 2 & 16 & $130801 \mathrm{~b}$ & F05 mw2 & 0.03719 & 0.00426 & 0.00087 & 0.006 & 0.05818 & 0.01900 & $\frac{0.00725}{0.00654}$ & $\frac{0.02168}{0.02121}$ & 0.08964 & 0.00052 & 0.00 & & & & & 0.02507 \\
\hline & 2 & 17 & & W-BATCH I STD-2 & 0.02629 & 0.00903 & 0.00075 & 0.00327 & 0.09604 & 0.02180 & $\frac{0.00654}{0.00890}$ & $\frac{0.02121}{0.01372}$ & 0.05962 & 0.00054 & 0.00 & & 0.00 & 0.00829 & & 0.03724 \\
\hline pha26 & 2 & 18 & $130775 \mathrm{~b}$ & & 0.01472 & 0.00714 & 0.00111 & 0.00636 & 0.07106 & $\frac{0.02100}{0.02264}$ & $\frac{0.00890}{0.00871}$ & $\frac{0.01372}{0.01568}$ & 0.06992 & 0.00048 & 0.00629 & & 0.00 & & & 0.02833 \\
\hline phin32 & 2 & 19 & $130792 \mathrm{~b}$ & W-Fo5mwl & 3809 & 0.00432 & 0.00086 & 0.00629 & 0.05778 & 0,01890 & $\frac{0.008 / 1}{n 00675}$ & 0.01568 & 0.06223 & 0.00052 & 0.00729 & & & 0.01623 & & 0.03928 \\
\hline pha12c & 2 & 20 & $130779 \mathrm{~b}$ & N-F12mwl & 0.01497 & 0.00770 & 0.00099 & 0.00794 & 0.07992 & $\frac{0.0109}{0.01997}$ & $\frac{0.00675}{0.00788}$ & 0.02106 & 0.05930 & 0.00053 & 0.00344 & & & & 0.0 & 0.03804 \\
\hline pha 20 & 2 & 22 & & -FlOmwl & 0.02945 & 0.00331 & 0.00079 & 0.00561 & 0.04894 & 0.02123 & & 0.01540 & 0.06406 & & 0.00775 & & 0.01 & 0.019 & & 0.04747 \\
\hline phal $18 \mathrm{c}$ & 2 & 24 & 13078 & V-F09mw & 0.01762 & 0.00883 & 0.00120 & 0.00841 & 0.095 & $\frac{0.04123}{0.01758}$ & & 0.01560 & 0.05660 & 0.00 & 0.00267 & & & & & 0.03758 \\
\hline Ustd & 2 & 25 & & V-USTD-2 & 0.02140 & 0.00941 & 0.00178 & 0.00012 & 0.09695 & 0.01454 & $\frac{0.00693}{0.0072 ?}$ & 0.01968 & 0.06490 & 0.000 & & & & & & 0.04526 \\
\hline pha20 & 2 & 29 & & V-Flomw2 & 0.02822 & 0.00328 & 0.00074 & 0.005 & 0.04880 & $\frac{0.01454}{0.02139}$ & $\frac{0.00722}{0.00700}$ & 0.02167 & 0.08964 & 0.00050 & 0.00879 & 0.20215 & & 0.02 & & 0.02495 \\
\hline pha17e & 2 & 30 & $130794 \mathrm{~b}$ & $M W$ - FI4mwI & 0.01532 & 0.00779 & 0.00125 & 0.00621 & 0.09385 & $\frac{0.02199}{0.01867}$ & 0.00700 & 0.01564 & 0.05476 & 0.00 & & 0.23846 & 0.00692 & & & 0.03811 \\
\hline Balch I & 2 & 33 & $130805 b$ & - BATCH I STD & 0.02549 & 0.00879 & 0.00073 & 0.00317 & 0.09298 & $\frac{0.01867}{0.02101}$ & $\frac{0.00615}{0.00861}$ & $\frac{0.02042}{0.01326}$ & $\frac{0.05866}{0.06740}$ & 0.00050 & 0.00943 & 0.20112 & & & & 0.03893 \\
\hline & & & & & & & & & & & & & 0.06740 & & & & & & & \\
\hline
\end{tabular}

Values at their detection limits were set to their detection limits. The CST Phase 4 glasses were analyzed with these PHA glasses. Their values are not presented here. See [8] for a complete listing which includes the CST glasses. 
Table A.3: Composition of PCT Leachate Solutions

\begin{tabular}{|c|c|c|c|c|c|c|c|c|c|c|c|c|c|c|c|c|c|c|}
\hline \multirow{3}{*}{$\begin{array}{c}\text { Glass } \\
\text { ID }\end{array}$} & \multirow[b]{3}{*}{ Blk } & \multirow[b]{3}{*}{ Seg } & \multirow[b]{3}{*}{ LIMS \# } & & \multirow{2}{*}{\multicolumn{5}{|c|}{$\begin{array}{l}\text { Concentrations in ppm } \\
\text { (as reported) }\end{array}$}} & \multirow{2}{*}{\multicolumn{5}{|c|}{$\begin{array}{c}\text { Concentrations in ppm } \\
\text { (after correcting for dilution) }\end{array}$}} & \multirow{2}{*}{\multicolumn{4}{|c|}{ Common Logarithm of ppm Concentrations }} \\
\hline & & & & & & & & & & & & & & & & & & \\
\hline & & & & Sample ID & $\mathrm{B}$ & $\mathrm{Li}$ & $\mathrm{Na}$ & $\mathrm{Pb}$ & $\mathrm{Si}$ & B & $\mathrm{Si}$ & $\mathrm{Na}$ & $\mathrm{Li}$ & $\mathrm{Pb}$ & $\log [\mathrm{B}]$ & $\log [\mathrm{Si}]$ & $\log [\mathrm{Na}]$ & $\log [\mathrm{Li}]$ \\
\hline sid & 1 & 1 & 130358 & PCT - Std-bl-1 & 19.467 & 9.920 & 82.739 & 0.029 & 48.894 & 19.467 & 48.894 & 82.739 & 9.920 & 0.029 & 1.28930 & 1.68926 & 1.91771 & 0.99651 \\
\hline pha20 & 1 & 2 & 130359 & PCT - U15 & 7.695 & 7.064 & 16.958 & 0.029 & 43.149 & 12.825 & 71.916 & 28.264 & 11,874 & 0.048 & 1.10807 & 1.85683 & 1.45123 & 1.07091 \\
\hline ARM & 1 & 6 & 130363 & PCT - U25 & 10.666 & 8.746 & 22.974 & 0.029 & 36.623 & 17.777 & 61.040 & 38.291 & 14.577 & 0.048 & 1.24986 & 1.78561 & 1.58309 & 1.16367 \\
\hline pha0l & 1 & 8 & 130365 & $\mathrm{PCT}-\mathrm{U} 70$ & 25.880 & 18.770 & 52.431 & 0.029 & 98.211 & 43.134 & 163.688 & 87.387 & 31.284 & 0.048 & 1.63482 & 2.21402 & 1.94145 & 1.49532 \\
\hline sid & 1 & 9 & 130366 & PCT - Sid-bl-2 & 19.758 & 10.106 & 84.244 & 0.029 & 49.510 & 19.758 & 49.510 & 84.244 & 10.106 & 0.029 & 1.29574 & 1.69469 & 1.92554 & 1.00458 \\
\hline blank & 1 & 12 & 130.369 & PCT - U22 & 0.040 & 0.004 & 0.140 & 0.029 & 0.049 & 0.067 & 0.082 & 0.233 & 0.007 & 0.048 & $-1,17608$ & -1.08795 & -0.63201 & -2.17608 \\
\hline phal7c & 1 & 15 & 130372 & PCT-U53 & 18.321 & 14,002 & 46.087 & 0.029 & 67.873 & 30.536 & 113.124 & 76.813 & 23.337 & 0.048 & 1.48481 & 2.05355 & 1.88544 & 1.36805 \\
\hline phallc & 1 & 16 & 130373 & PCT - U80 & 16.104 & 12.604 & 36.821 & 0.029 & 72.007 & 26.841 & 120.014 & 61.370 & 21.007 & 0.048 & 1.42879 & 2.07923 & 1.78795 & 1.32237 \\
\hline pha05 & $i$ & 17 & 130374 & PCT - U21 & 19.500 & 15.079 & 40.172 & 0.029 & 83.599 & 32.501 & 139.335 & 66.955 & 25.132 & 0.048 & 1.51189 & 2.14406 & 1.82578 & 1.40023 \\
\hline std & 1 & 18 & 130375 & PCT - sld-bl-3 & 19.669 & 10.002 & 83.454 & 0.029 & 48.968 & 19.669 & 48.968 & 83.454 & 10.002 & 0.029 & 1.29378 & 1.68991 & 1.92145 & 1.00009 \\
\hline sid & 2 & 1 & 130376 & STD-B2-1 & 19.376 & 9.692 & 81.811 & 0.044 & 49.598 & 19.376 & 49.598 & 81.811 & 9.692 & 0.044 & 1.28726 & 1.69546 & 1.91281 & 0.98641 \\
\hline pha05 & 2 & 4 & 130379 & $\begin{array}{l}\text { U78 } \\
\end{array}$ & 19.103 & 14.526 & 39.357 & 0.060 & 84.950 & 31.839 & 141.586 & 65.596 & 24.210 & 0.100 & 1.50296 & 2.15102 & 1.81688 & 1.38400 \\
\hline pha0l & 2 & 5 & 130380 & U61 & 25.208 & 18.027 & 50.859 & 0.058 & 99.572 & 42.014 & 165.957 & 84.767 & 30.046 & 0.097 & 1.62340 & 2.22000 & 1.92823 & 1.47778 \\
\hline blank & 2 & 6 & 130381 & U79. & 0.046 & 0.015 & 0.223 & 0.033 & 0.114 & 0.077 & 0.190 & 0.372 & 0.025 & 0.055 & -1.11538 & -0.72124 & -0.42984 & -1.60205 \\
\hline phal $7 \mathrm{c}$ & 2 & 8 & 130383 & U71 & 16.346 & 12.096 & 41.316 & 0.054 & 68.290 & 27.244 & 113.819 & 68.861 & 20.160 & 0.090 & 1.43527 & 2.05622 & 1.83798 & 1.30450 \\
\hline std & 2 & 9 & 130384 & STD-B2-2 & 19.467 & 9.705 & 81.562 & 0.046 & 49.333 & 19.467 & 49.333 & 81.562 & 9.705 & 0.046 & 1.28930 & 1.69314 & 1.91149 & 0.98700 \\
\hline ARM & 2 & 11 & 130386 & U31 & 10.834 & 8.533 & 22.828 & 0.056 & 37.276 & 18.057 & 62.128 & 38.047 & 14.222 & 0.093 & 1.25665 & 1.79329 & 1.58033 & 1.15296 \\
\hline phal Ic & 2 & 13 & 130388 & U56 & 16.630 & 12.671 & 37.466 & 0.063 & 73.560 & 27.717 & 122.603 & 62.445 & 21.119 & 0.105 & 1.44275 & 2.08850 & 1.79550 & 1.32467 \\
\hline pha20 & 2 & 15 & 130390 & U39 & 8.791 & 7.793 & 18.940 & 0.056 & 47.755 & 14.652 & 79.593 & 31.567 & 12.989 & 0.093 & 1.16590 & 1.90088 & 1.49924 & 1.11356 \\
\hline std & 2 & 18 & 130393 & STD-B2-3 & 19.419 & 9.658 & 81.390 & 0.049 & 49.189 & 19.419 & 49.189 & 81.390 & 9.658 & 0.049 & 1.28823 & 1.69187 & 1.91057 & 0.98489 \\
\hline std & 3 & 1 & 130394 & STD-B3-1 & 19.113 & 9.522 & 80.567 & 0.047 & 48.760 & 19.113 & 48.760 & 80.567 & 9.522 & 0.047 & 1.28133 & 1.68806 & 1.90616 & 0.97873 \\
\hline pha05 & 3 & 2 & 130395 & U18 & 19.146 & 14.629 & 39.472 & 0.060 & 84.914 & 31.911 & 141.526 & 65.788 & 24.382 & 0.100 & 1.50394 & 2.15084 & 1.81815 & 1.38707 \\
\hline pha0l & 3 & 5 & 130398 & U60 & 24.418 & 17.562 & 49.704 & 0.049 & 96.916 & 40.697 & 161.530 & 82.842 & 29.271 & 0.082 & 1.60957 & 2.20825 & 1.91825 & 1.46643 \\
\hline pha20 & 3 & 6 & 130399 & U72 & 7.776 & 7.025 & 16.932 & 0.055 & 44.519 & 12.960 & 74.200 & 28.221 & 11.709 & 0.092 & 1.11261 & 1.87040 & 1.45057 & 1.06850 \\
\hline std & 3 & 9 & 130402 & STD-B3-2 & 19.265 & 9.648 & 81.451 & 0.053 & 49.003 & 19.265 & 49.003 & 81.451 & 9.648 & 0.053 & 1.28477 & 1.69022 & 1.91090 & 0.98444 \\
\hline phal7c & 3 & II & 130404 & $\mathrm{U} 81$ & 17.668 & 13.075 & 44.236 & 0.045 & 68.667 & 29.447 & 114.447 & 73.728 & 21.792 & 0.075 & 1.46905 & 2.05861 & 1.86763 & 1.33830 \\
\hline phalle & 3 & 13 & 130406 & $\mathrm{U} 26$ & 15.094 & 11.763 & 35.089 & 0.051 & 70.979 & 25.157 & 118.301 & 58.483 & 19.605 & 0.085 & 1.40066 & 2.07299 & 1.76703 & 1.29238 \\
\hline ARM & 3 & 15 & 130408 & U49 & 10.834 & 8.521 & 22.911 & 0.043 & 36.743 & 18.057 & 61.240 & & 14.202 & 0.072 & 1.25665 & 1.78703 & 1.58190 & 1.15235 \\
\hline sid & 3 & 17 & 130410 & STD-B3-3 & 19.339 & 9.711 & 82.099 & 0.035 & 49.310 & 19.339 & 49.310 & 82.099 & 9.711 & 0.035 & 1.28643 & 1.69294 & 1.91434 & 0.98726 \\
\hline std & 4 & 1 & 130411 & STD-B4-1 & 19.165 & 9.690 & 81.752 & 0.042 & 48.956 & 19.165 & 48.956 & 81.752 & 9.690 & 0.042 & 1.28251 & 1.68981 & 1.91250 & 0.98632 \\
\hline pha 03 & 4 & 2 & 130412 & PCT - U24 & 30.246 & 19.709 & 57.031 & 0.045 & 96.535 & 50.411 & 160.895 & 95.054 & 32.849 & 0.0 & 1.70253 & 2.20654 & 1.97797 & 1.51652 \\
\hline pha04 & 4 & 3 & 0413 & PCT - U55 & 25.802 & 20.743 & 53.426 & 0.089 & 113.181 & 43.004 & 188.639 & 89.045 & 34.572 & 0.148 & 1.63351 & 2.27563 & 1.94961 & 1.53873 \\
\hline pha06 & 4 & 5 & 130415 & PCT - U29 & 26.071 & 17.434 & 51.640 & 0.029 & 89.886 & 43.453 & 149.813 & 86.068 & 29.057 & 0.048 & 1.63802 & 2.17555 & 1.93484 & 1.46325 \\
\hline phal $8 \mathrm{c}$ & 4 & 8 & 130418 & PCT - U23 & 26.878 & 15.967 & 58.565 & 0.032 & 74.546 & 44.798 & 124.246 & 97.610 & 26.612 & 0.053 & 125 & 2.09428 & 1.98950 & 1.42508 \\
\hline sid & 4 & 9 & 130419 & PCT - STD-B4-2 & 19.377 & 9.759 & 82.363 & 0.029 & 49.126 & 19.377 & 49.126 & 82.363 & 9.759 & 0.029 & 729 & 1.69131 & 1.91573 & 0.98941 \\
\hline pha26 & 4 & 11 & 130421 & PCT - U62 & 6.956 & 6.290 & 16.621 & 0.030 & 41.026 & 11.594 & 68.378 & 27.702 & 10.484 & 0.050 & 1.06422 & 1.83492 & 1.44252 & $1.0205 \mathrm{~T}$ \\
\hline EA & 4 & 13 & 130423 & PCT - U07 & 38.600 & 12.142 & 111.398 & 0.039 & 57.005 & 643.346 & 950.102 & 1856.670 & 202.371 & 0.065 & 2.80845 & 2.97777 & 3.26874 & 2.30615 \\
\hline plia02 & 4 & 14 & 130424 & PCT - U36 & 19.714 & 15.355 & 41.745 & 0.038 & 85.842 & 32.857 & 143.073 & 69.576 & 25.592 & 0.0 & 1.51663 & 2.15556 & 1.84246 & 1.40811 \\
\hline phal2c & 4 & 15 & 130425 & PCT - U75 & 28.647 & 18.380 & 58.580 & 0.041 & 88.212 & 47.746 & 147.023 & 97.635 & 30.634 & 0.6 & 1.67894 & 2.16739 & 1.98961 & 1.48620 \\
\hline pha3.32 & 4. & 16 & 130426 & PCT - U74 & 6.784 & 6.091 & 17.489 & 0.052 & 39.855 & 11.307 & 66.426 & 29.149 & 10.152 & 0.087 & 1.05334 & 1.82234 & 1.46462 & 1.00655 \\
\hline 310 & 4 & 17 & 130427 & PCT - STD-B4-3 & 19.309 & 9.719 & 82.229 & 0.034 & 49.077 & 19.309 & 49.077 & 82.229 & 9.719 & 0.034 & 1.28576 & 1.69088 & 1.91503 & 0.98762 \\
\hline
\end{tabular}

Notes:

(1). Values that are below detection (indicated by a "<") were converted to their detection limit.

(2) The CST Phase 3 and PHA Phases 3 and 4 glasses are also shown in this table (since they were part of the analytical plan). However, no analyses of these data are included in this report. 


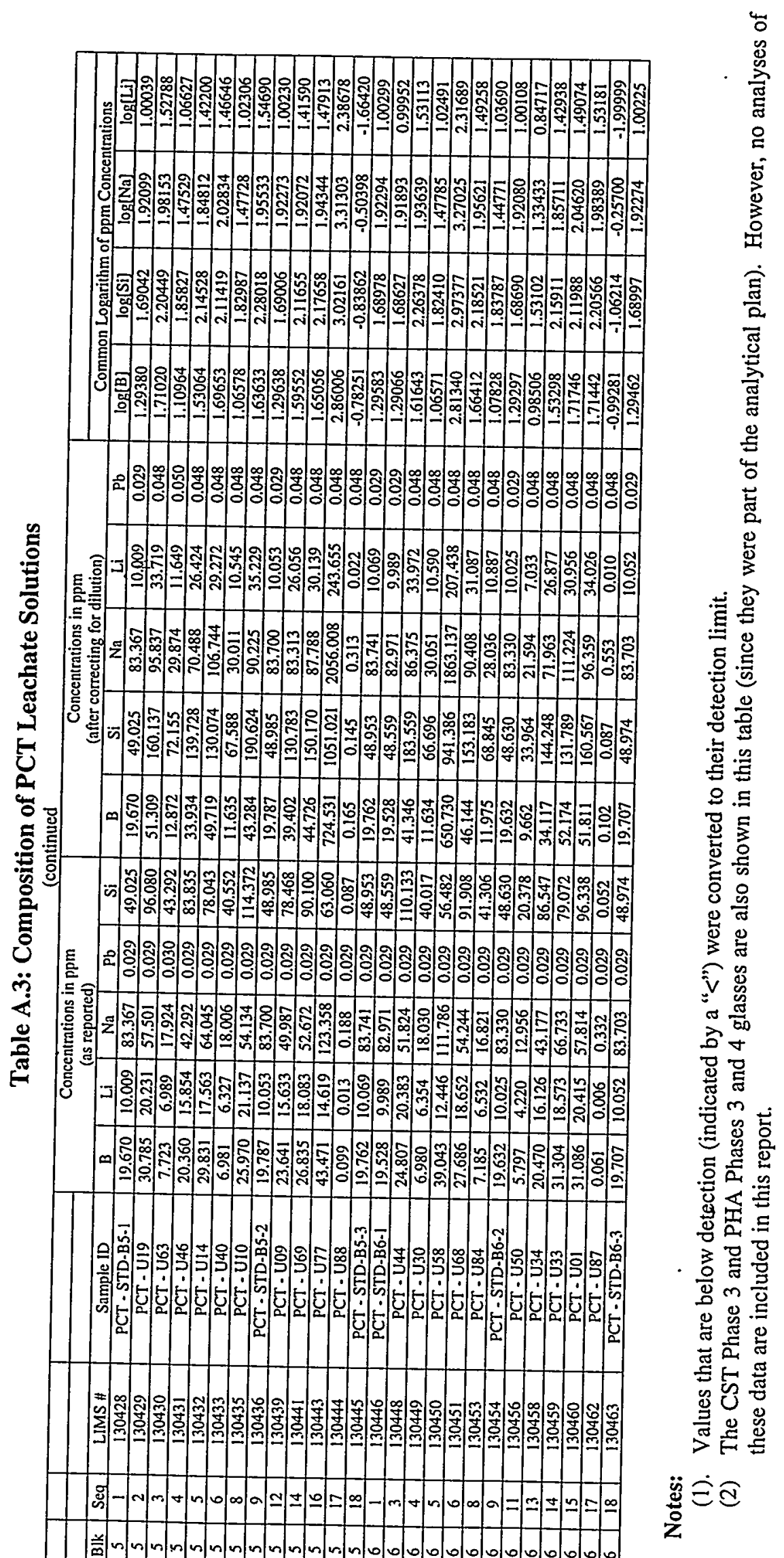


Exhibit A.1: Measurements by Glass Sample $\mathrm{I}$ by Oxide

Al203 By Glass Sample ID

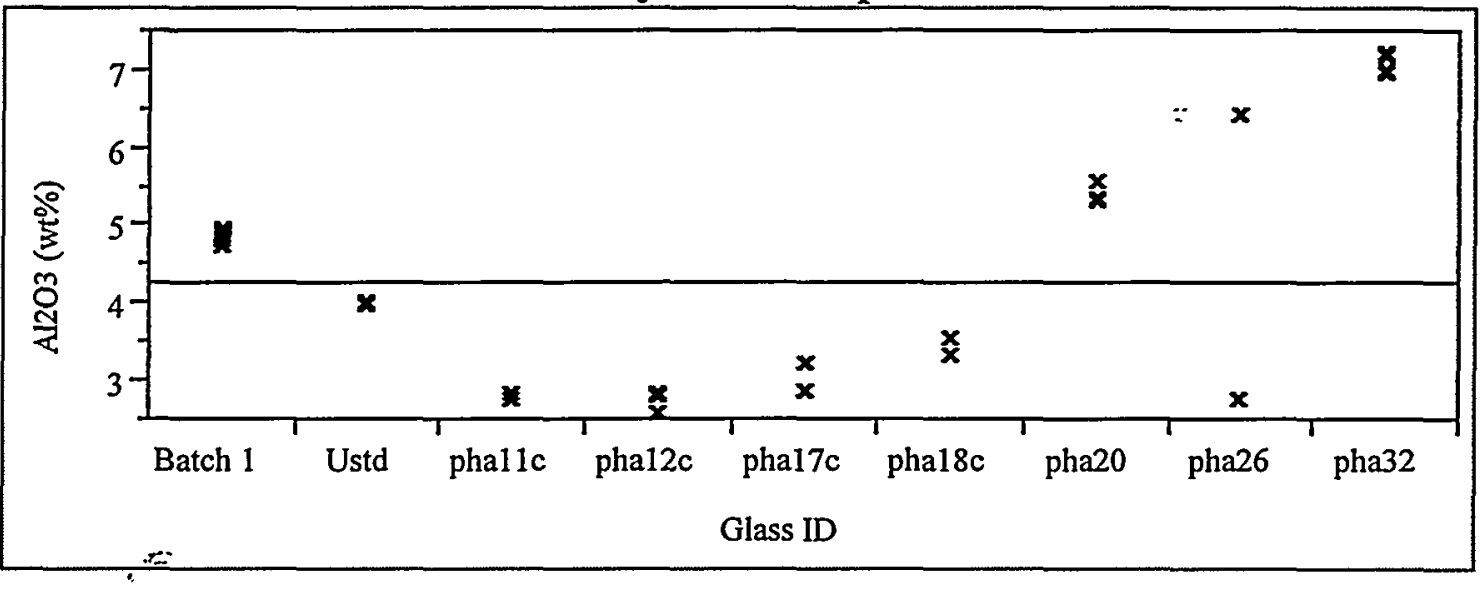

B2O3 By Glass Sample ID

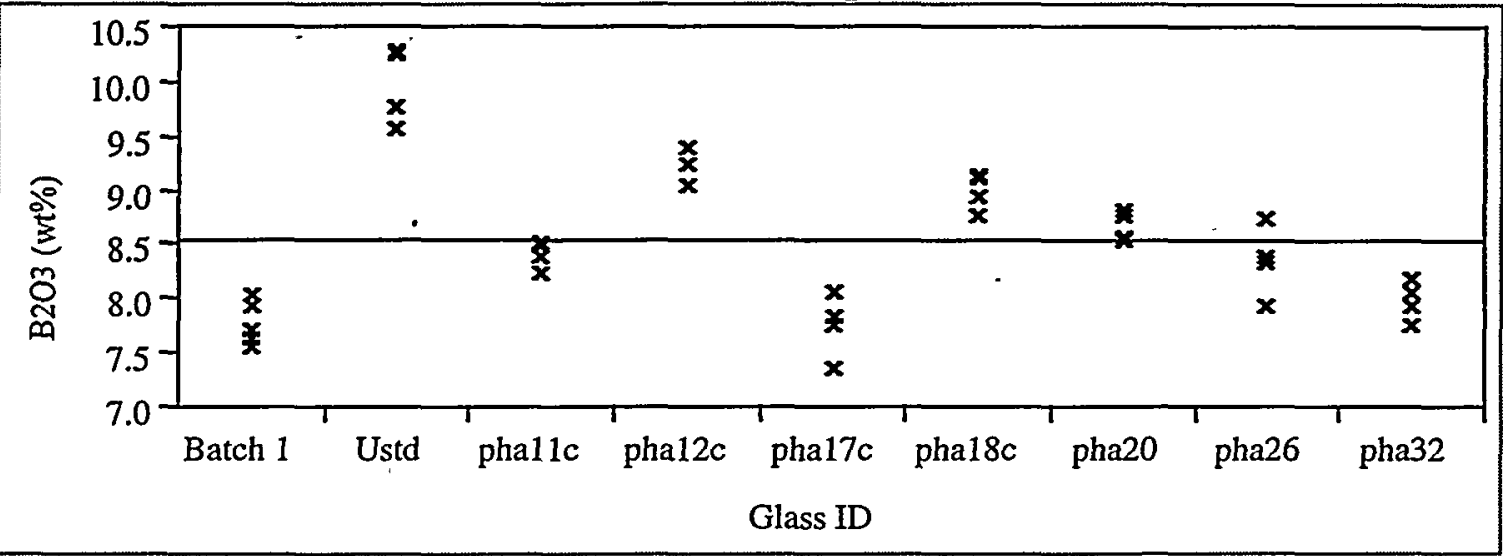

CaO MW By Glass Sample ID

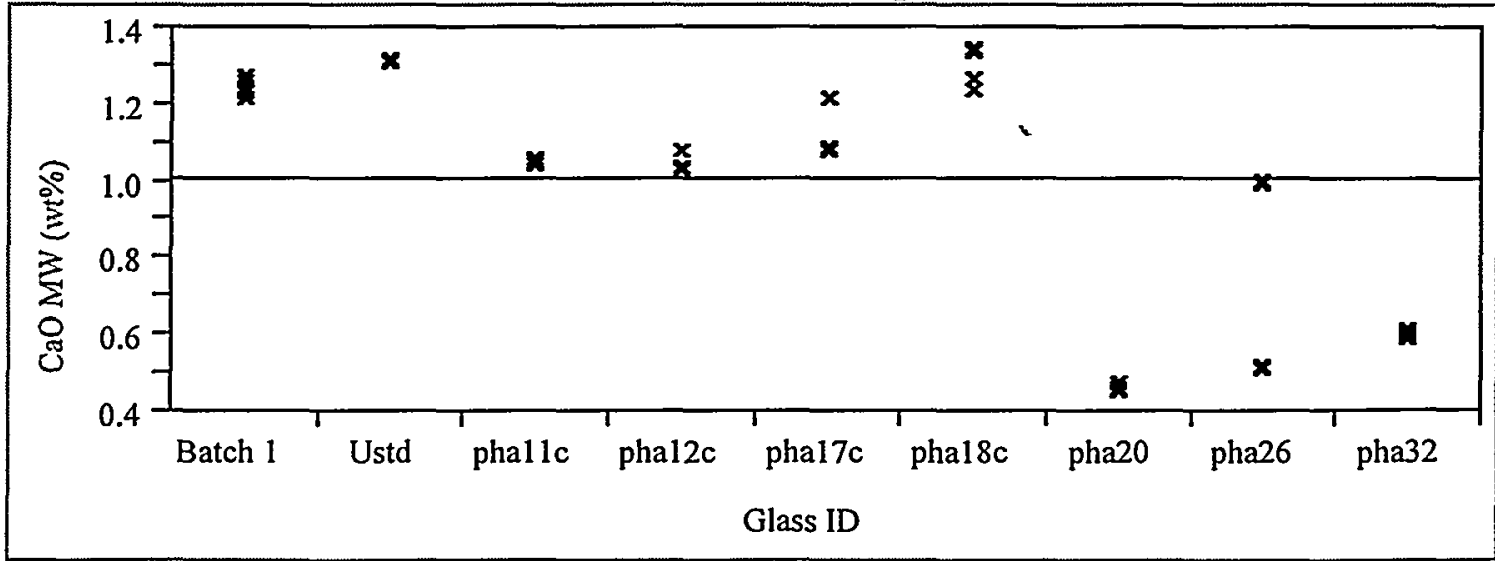


Exhibit A.1: Measurements by Glass Sample ID by Oxide (continued)

\section{CaO pf By Glass Sample ID}

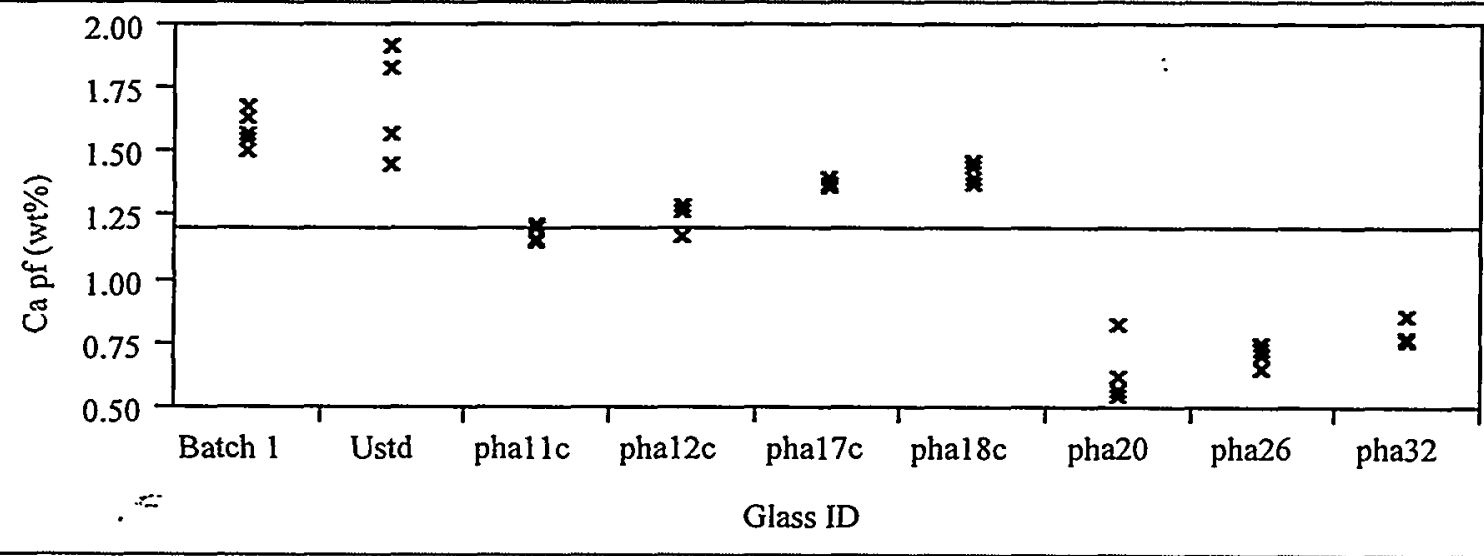

CaO By Glass Sample ID

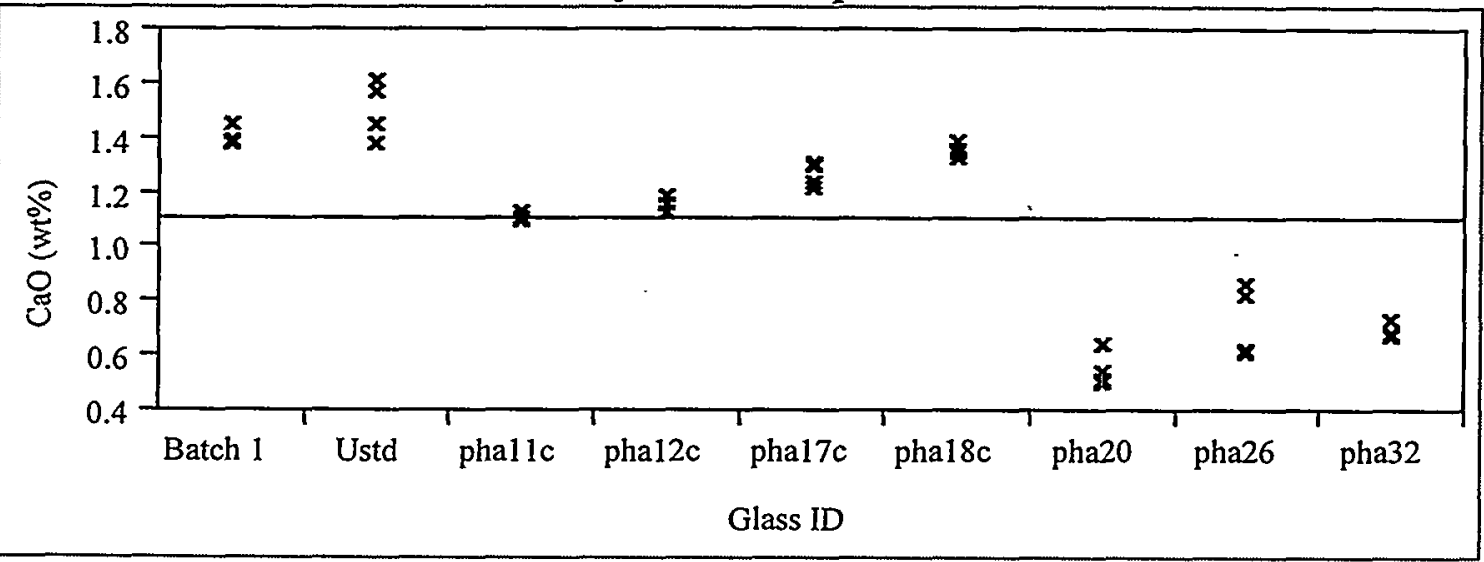

\section{Cr203 By Glass Sample ID}

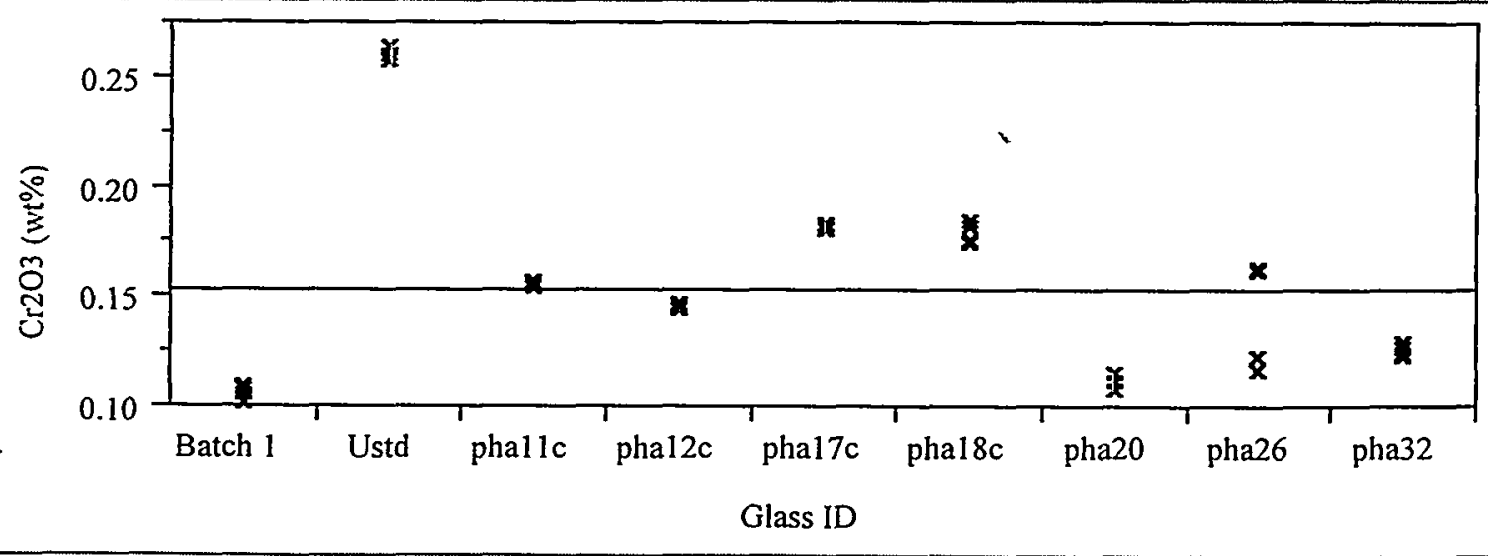


Exhibit A.1: Measurements by Glass Sample ID by Oxide (continued)

\section{CuO By Glass Sample ID}

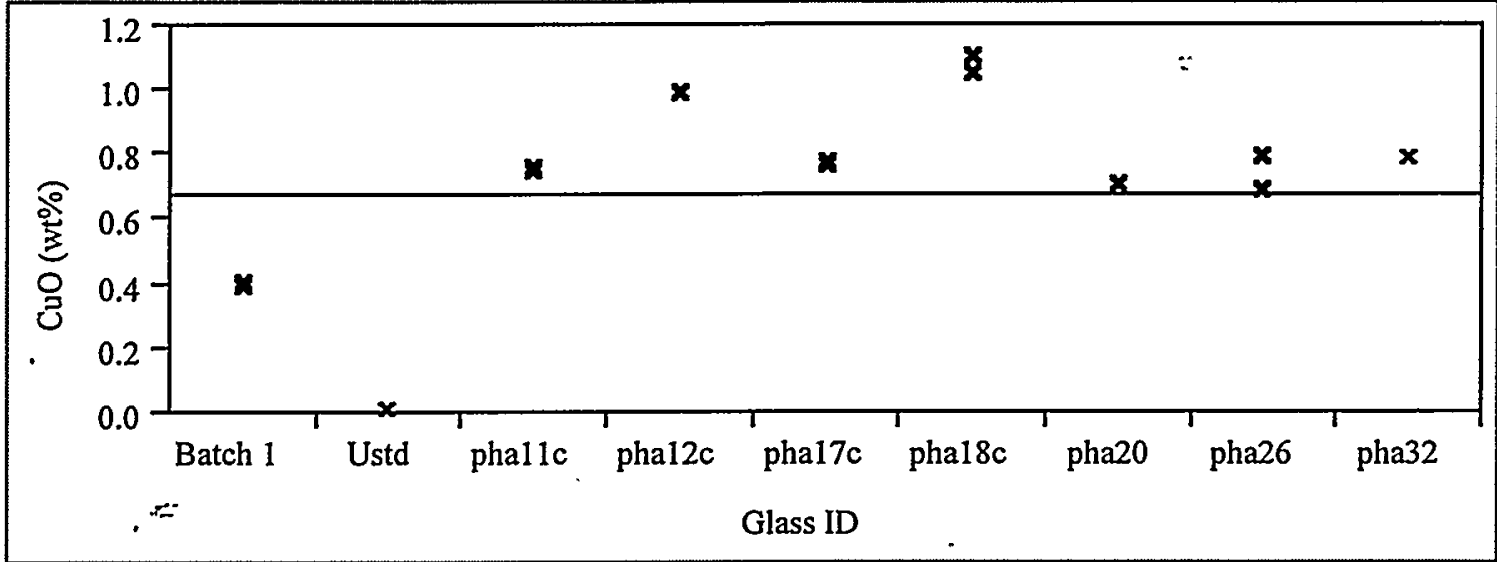

Fe203 By Glass Sample ID

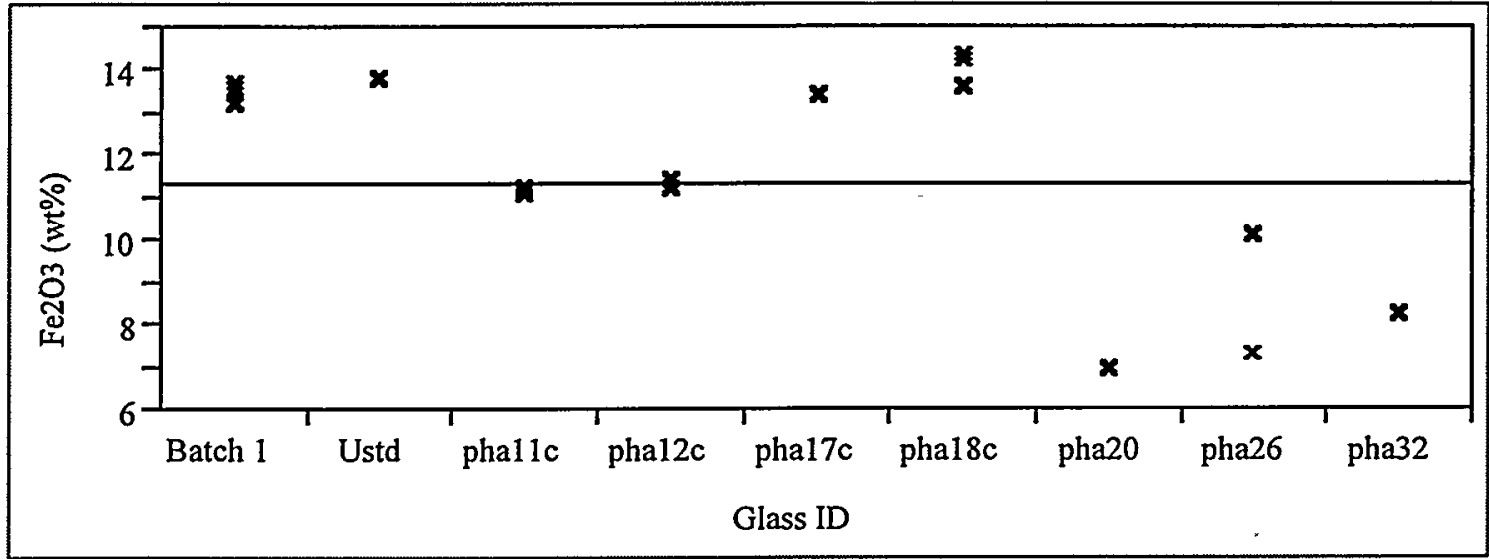

K20 By Glass Sample ID

\begin{tabular}{|c|c|c|c|c|c|c|c|c|c|c|}
\hline \multirow{3}{*}{ 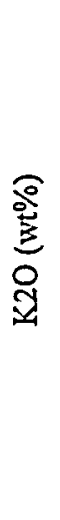 } & $\begin{array}{l}6.0- \\
5.5- \\
5.0- \\
4.5-\end{array}$ & & & $x$ & $\begin{array}{l}\mathbf{x} \\
\mathbf{x} \\
\boldsymbol{x}\end{array}$ & $\begin{array}{r}\mathbf{x} \\
\mathbf{x} \\
\end{array}$ & $\begin{array}{l}\mathbf{x} \\
\mathbf{x} \\
\mathbf{x}\end{array}$ & \multirow[t]{2}{*}{ * } & \multirow[t]{2}{*}{$x$} & \multirow{2}{*}{$\frac{x}{x}$} \\
\hline & $\begin{array}{l}4.0- \\
3.5- \\
3.0-\end{array}$ & $\begin{array}{l}\frac{y}{x} \\
x \\
x\end{array}$ & $\begin{array}{l}\mathbf{x} \\
\mathbf{x}\end{array}$ & $x$ & & & & & & \\
\hline & & Batch 1 & Ustd & phallc & phal2c & $\begin{array}{l}\text { pha17c } \\
\text { Glass ID }\end{array}$ & phal 8c & pha20 & pha26 & pha32 \\
\hline
\end{tabular}


Exhibit A.1: Measurements by Glass Sample ID by Oxide (continued)

Li2O By Glass Sample ID

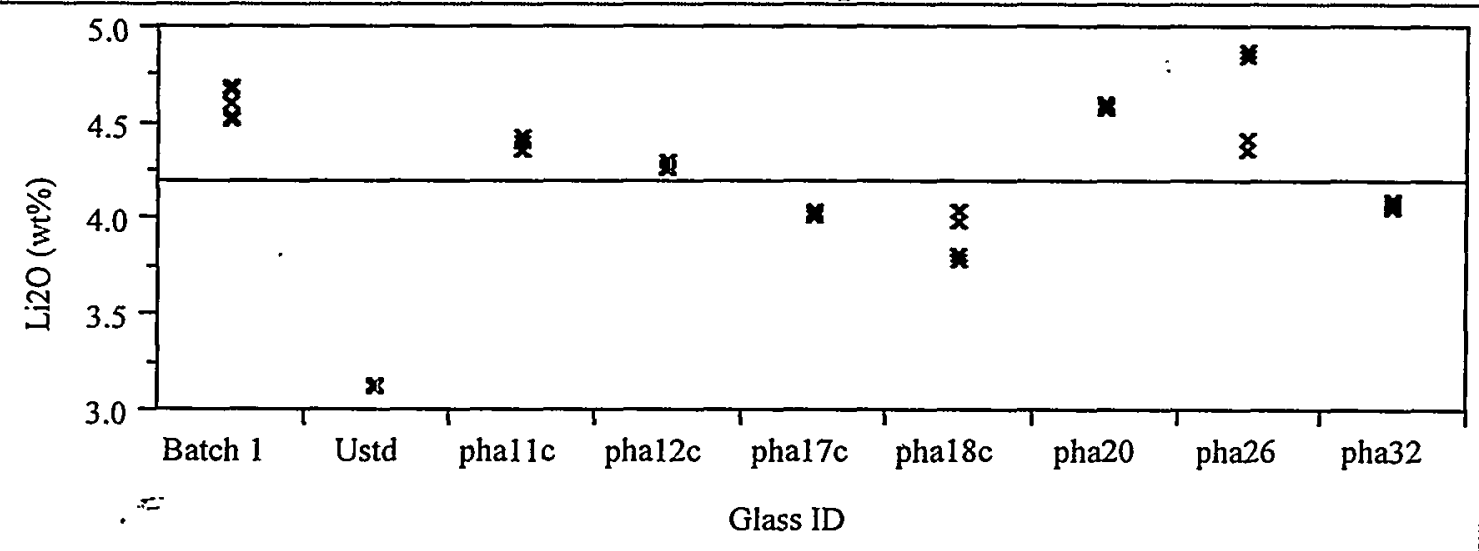

MgO By Glass Sample ID

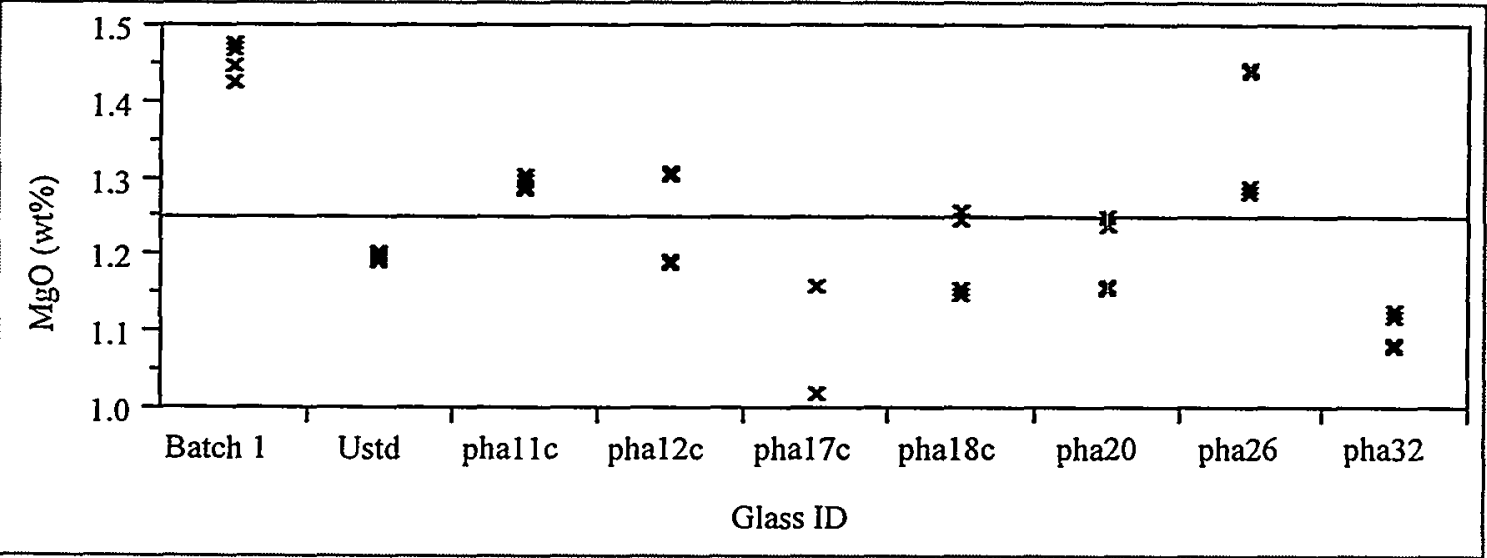

MnO By Glass Sample ID

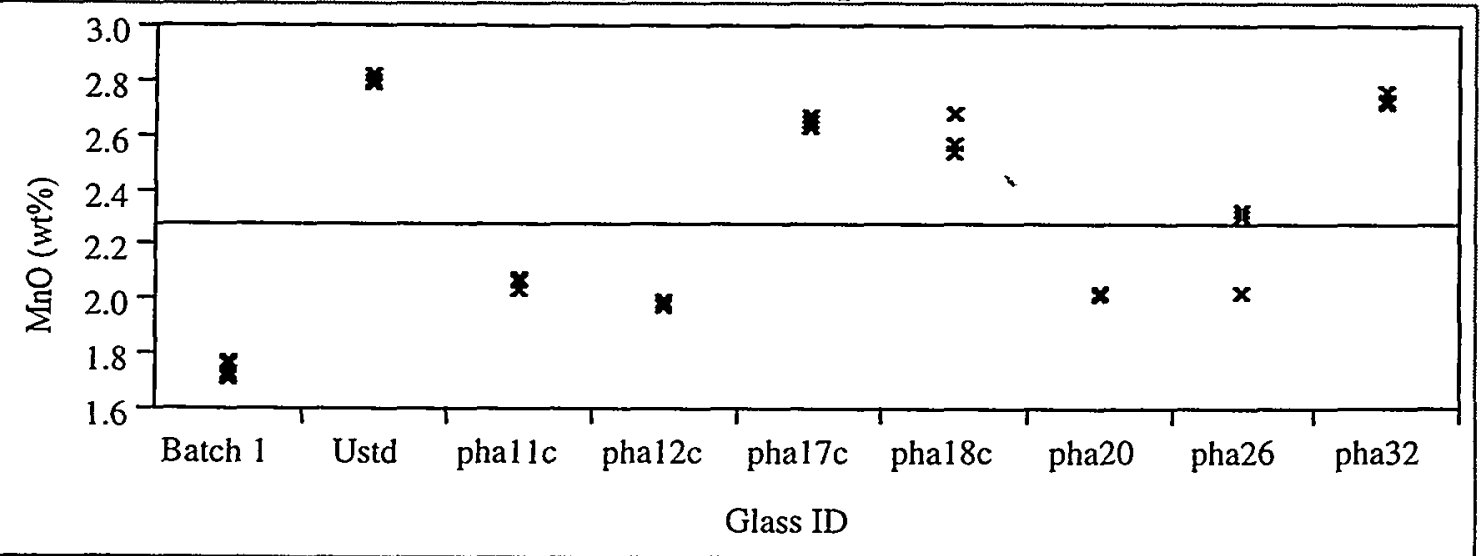


Exhibit A.1: Measurements by Glass Sample ID by Oxide (continued)

\section{Na20 By Glass Sample ID}

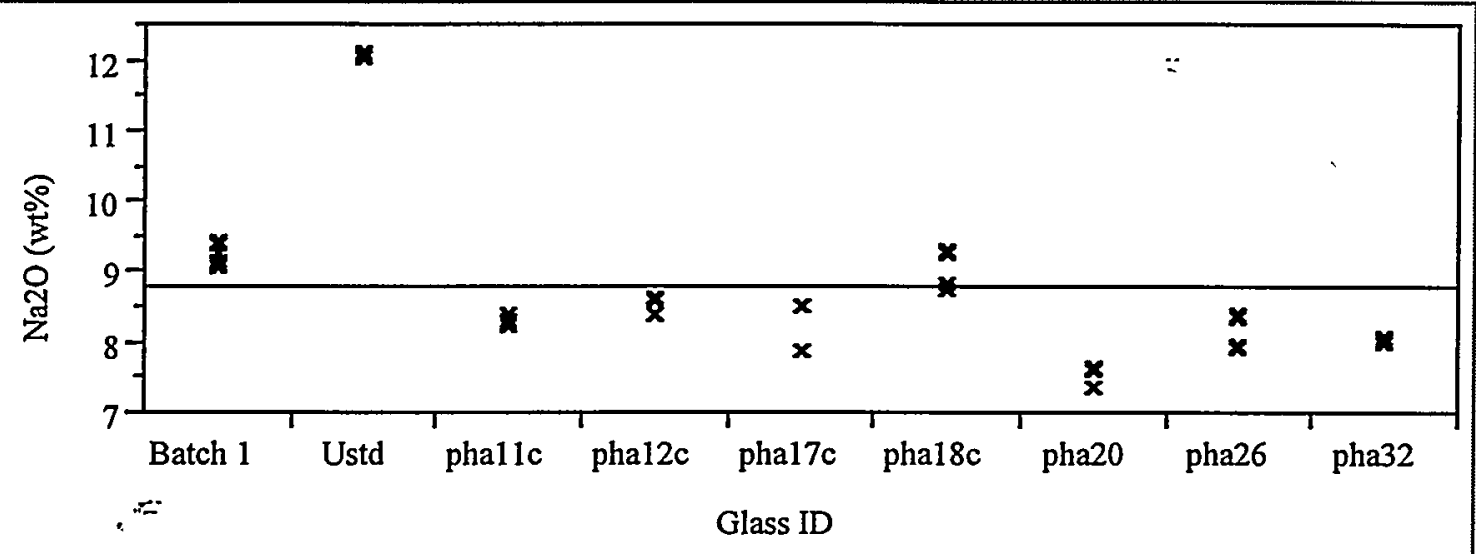

NiO By Glass Sample ID

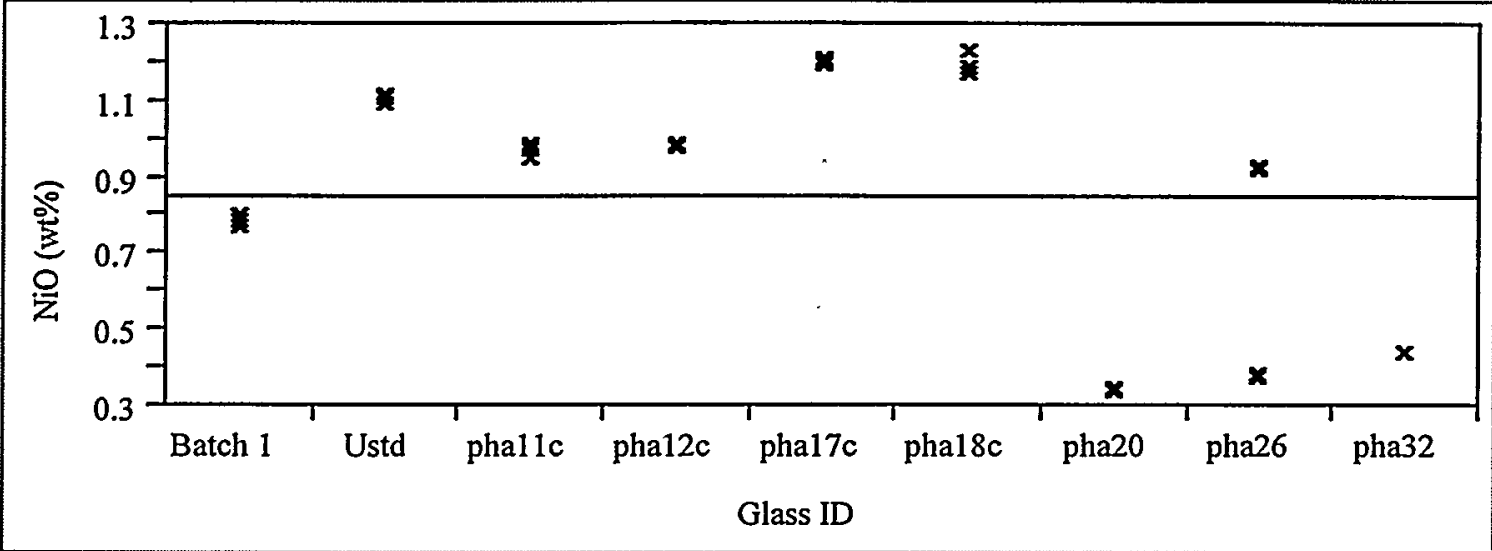

SiO2 MW By Glass Sample ID

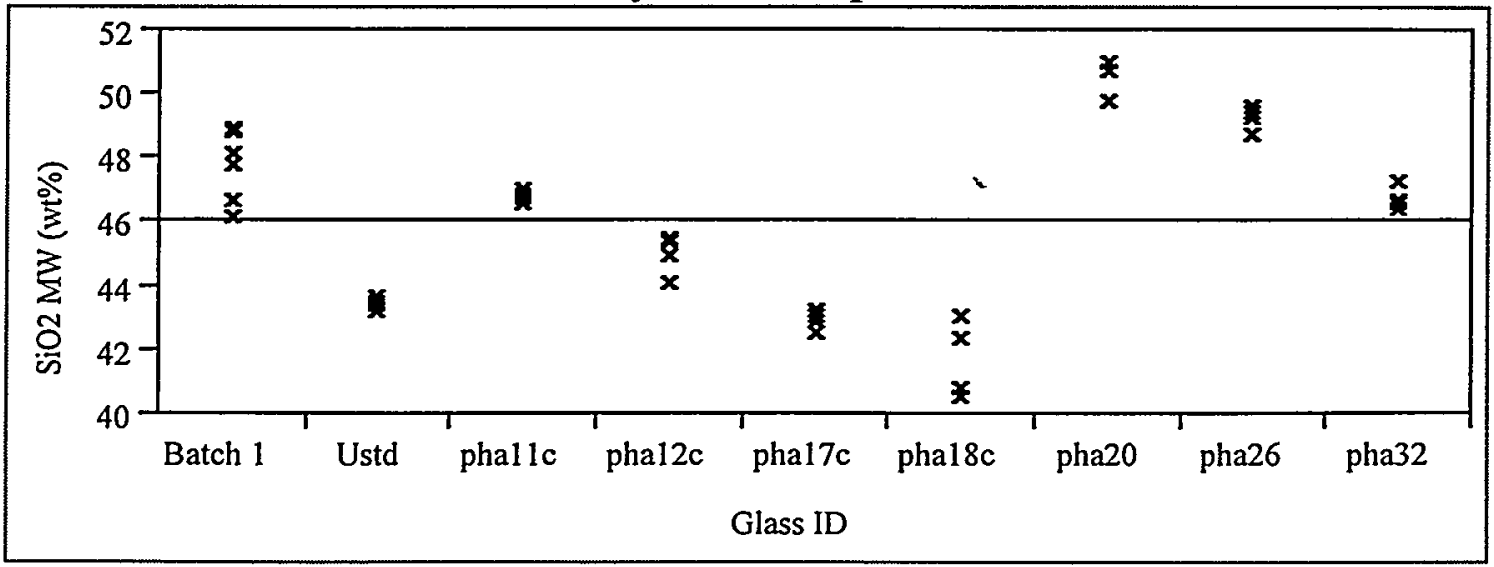


Exhibit A.1: Measurements by Glass Sample $\mathrm{W}$ by Oxide (continued)

SiO2 pf By Glass Sample ID

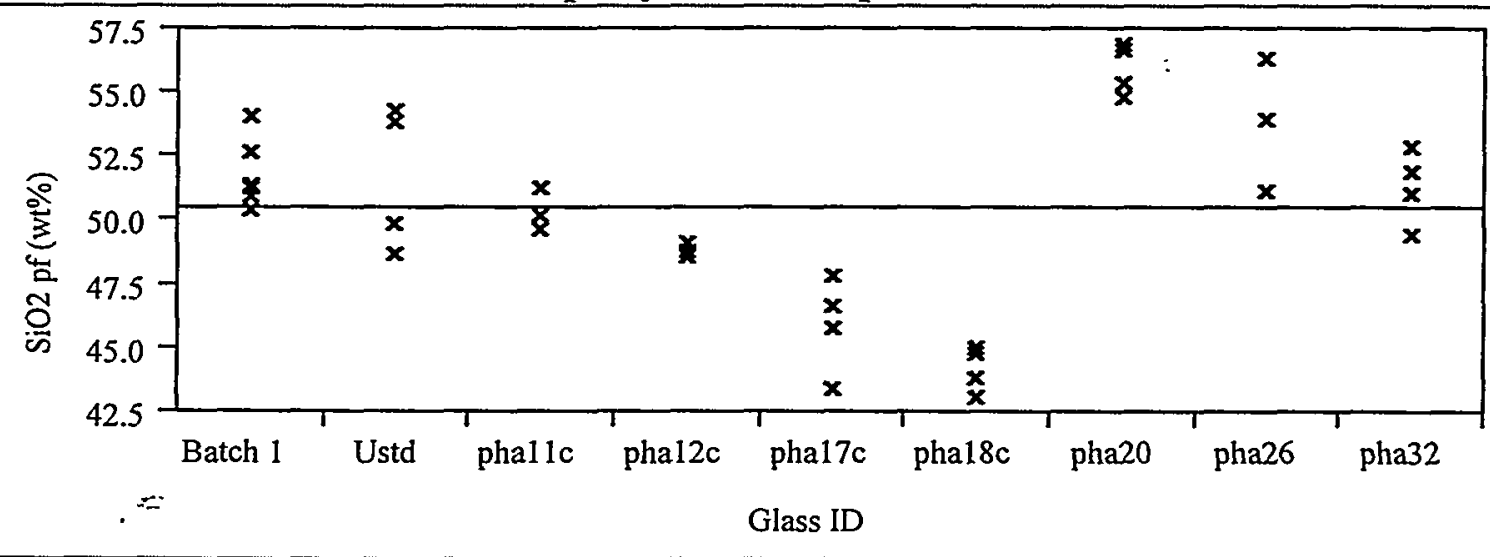

SiO2 By Glass Sample ID

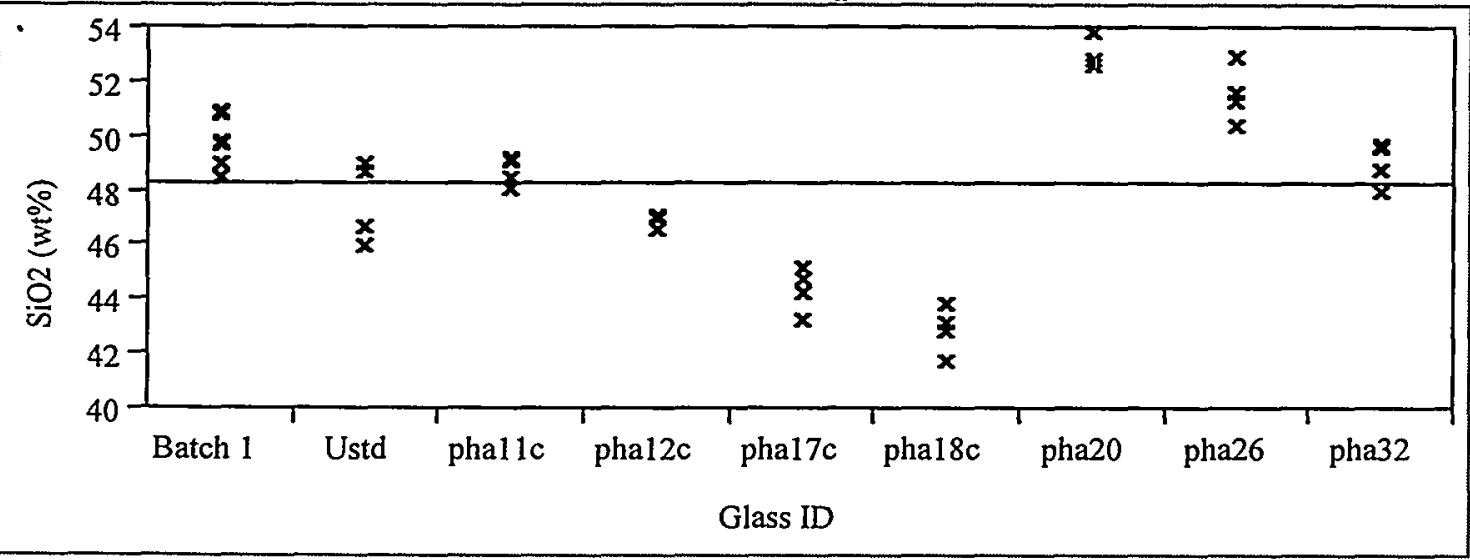

TiO2 By Glass Sample ID

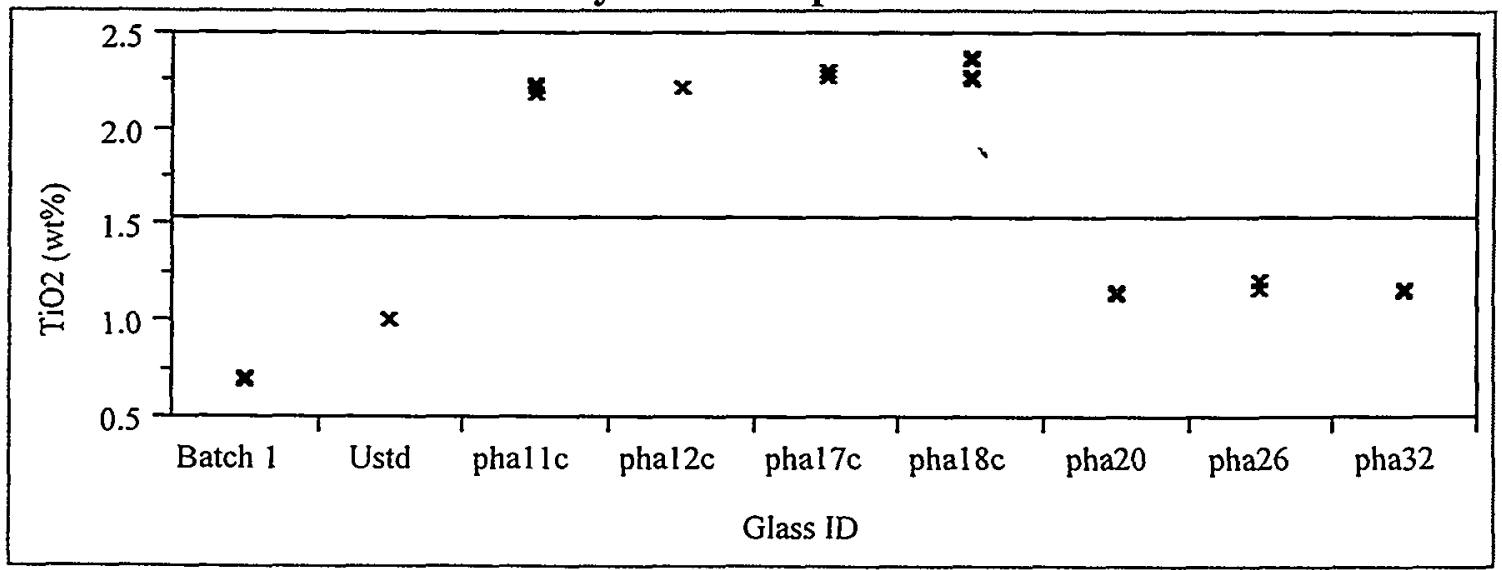


Exhibit A.1: Measurements by Glass Sample ID by Oxide (continued)

U308 By Glass Sample ID

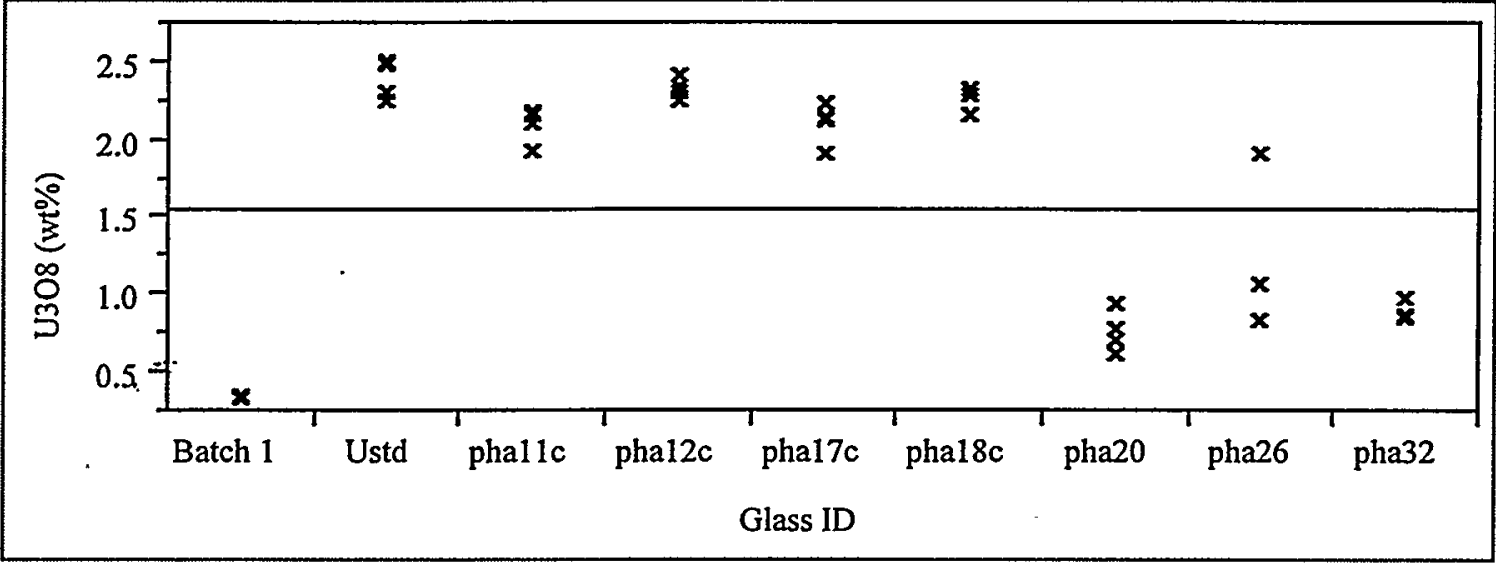

\section{ZrO2 By Glass Sample ID}

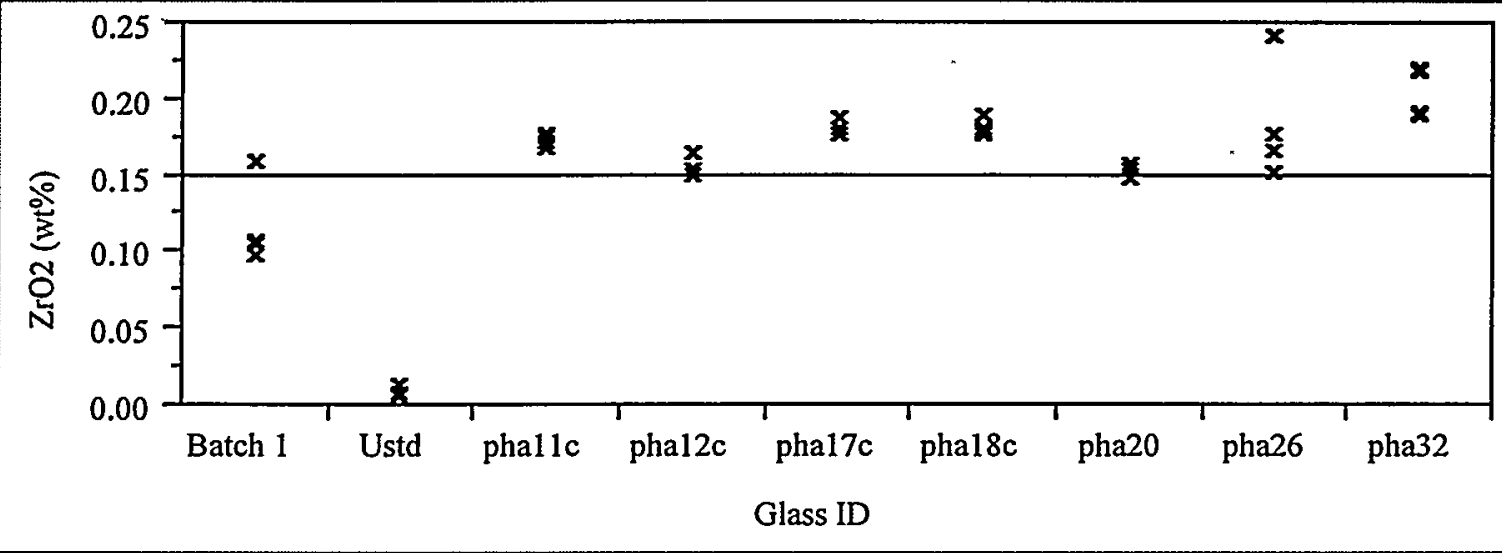

Sum of Oxides By Glass Sample ID

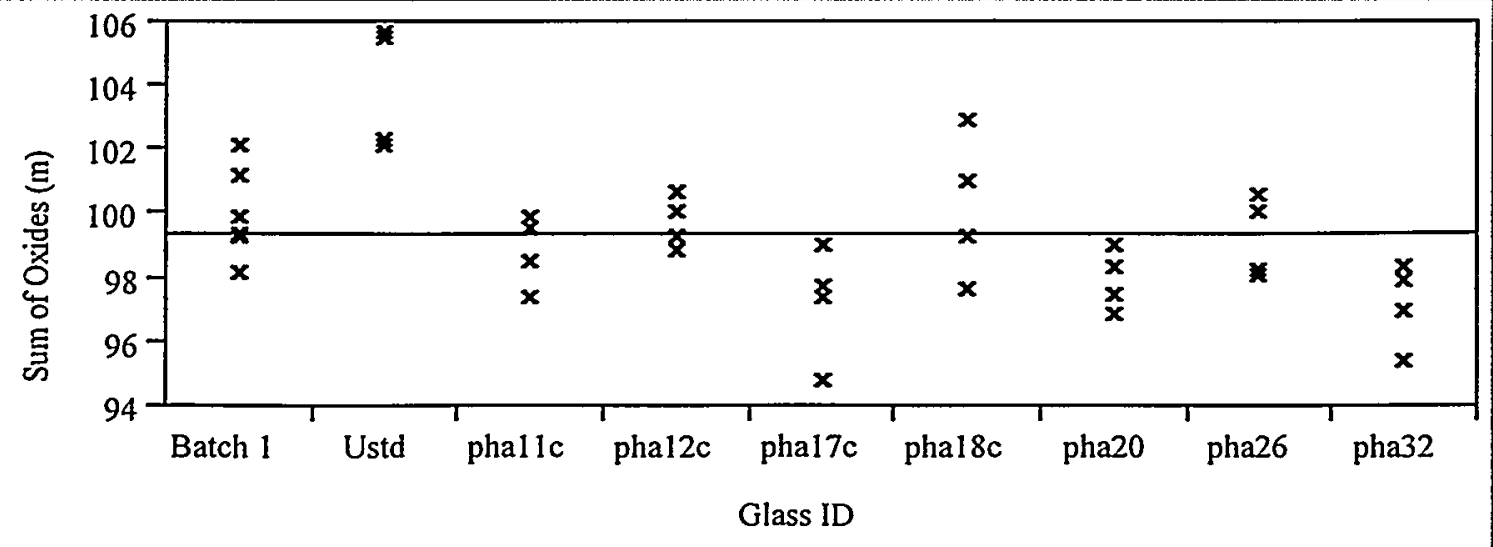


Exhibit A.2: Peroxide Fusion Measurements of Glass Standards by Oxide

(+ u-std; small square Batch 1 standard)

$\mathrm{B2O3}(\mathrm{wt} \%)$ By

Block (pf)

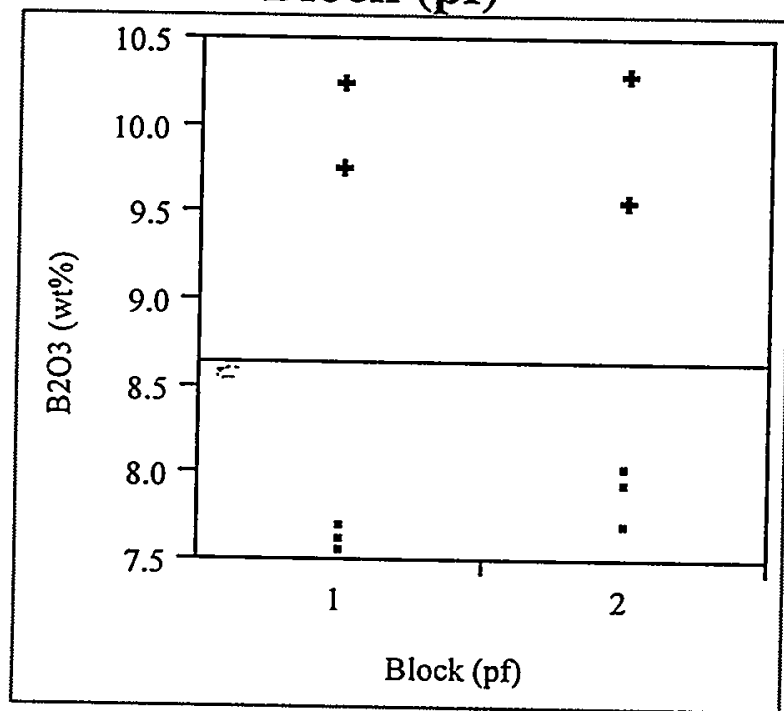

Ca pf (wt\%) By

Block (pf)

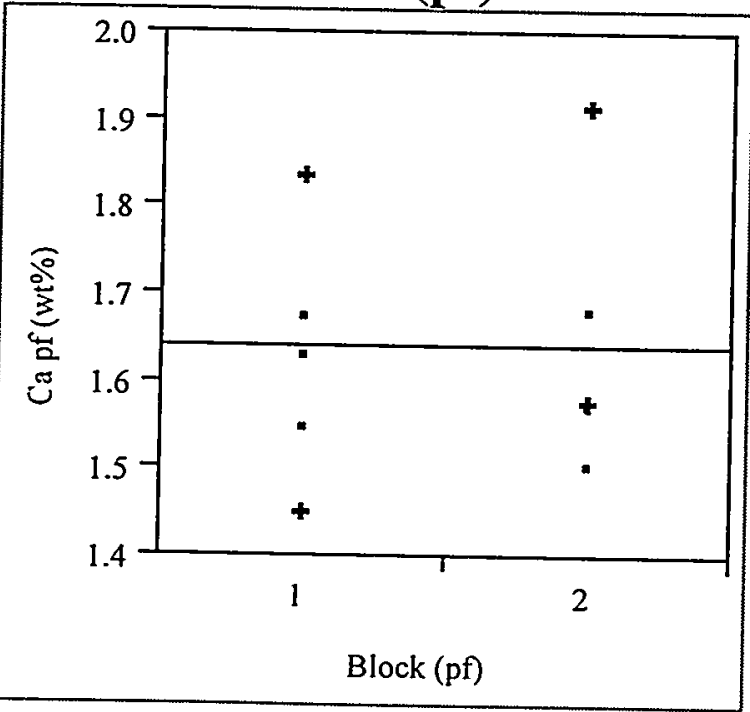

$\mathrm{SiO} 2 \mathrm{pf}(\mathrm{wt} \%)$ By Block

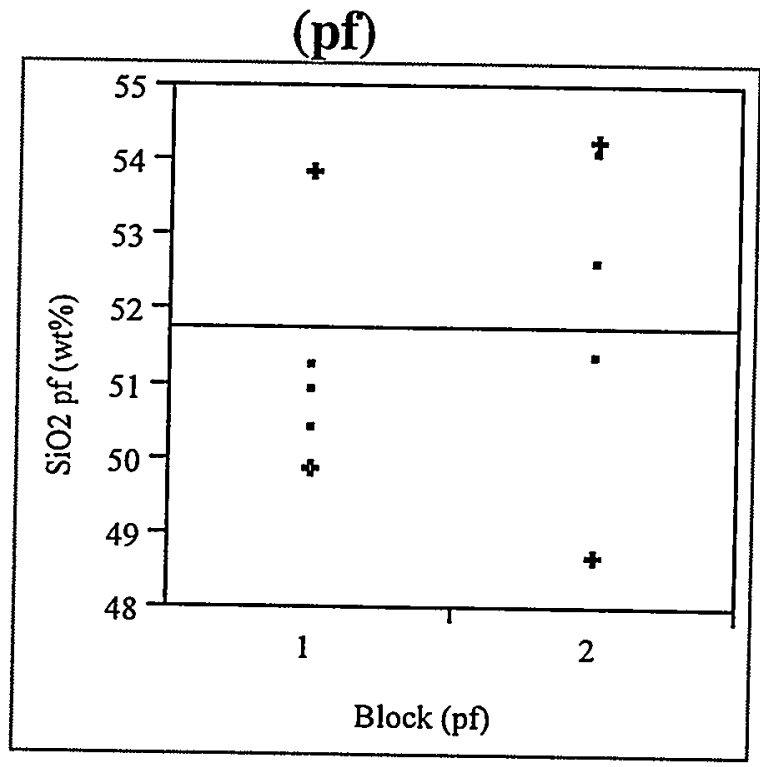


Exhibit A.3: Measurements of Glass Standards by Oxide (+ u-std; small square Batch 1 standard)

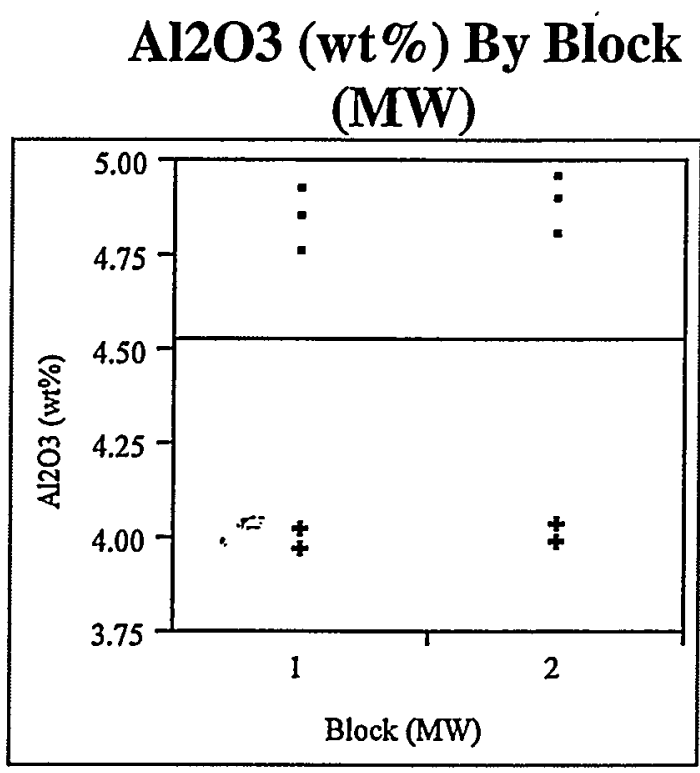

$\mathrm{CaO}$ MW (wt\%) By Block (MW)

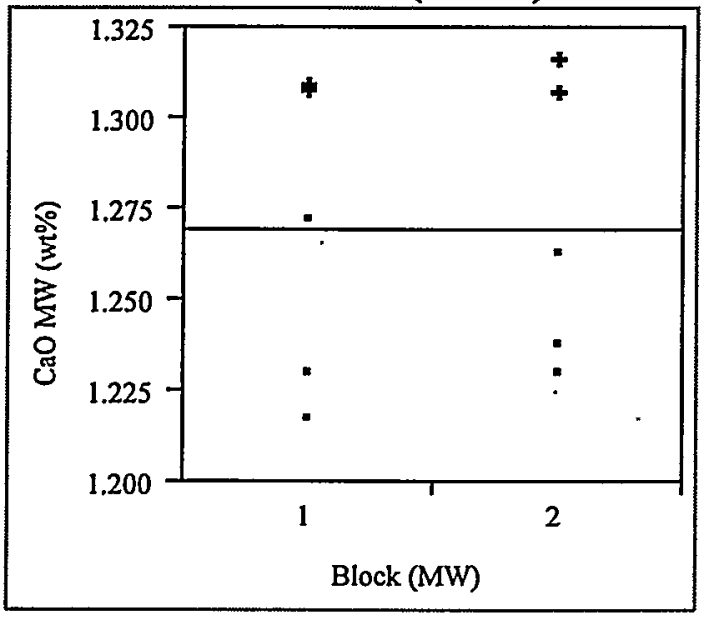

Cr203 (wt\%) By Block (MW)

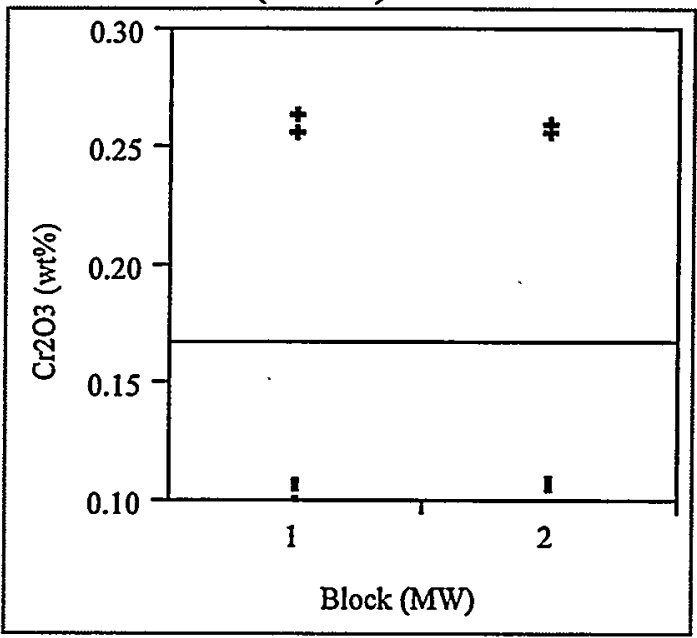

CuO (wt\%) By Block

(MW)

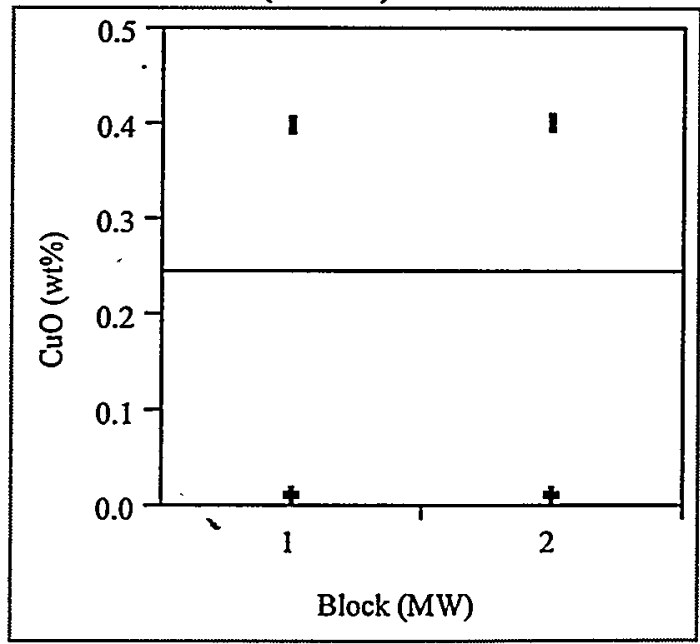


Exhibit A.3: Measurements of Glass Standards by Oxide (+ u-std; small square Batch 1 standard) (continued)

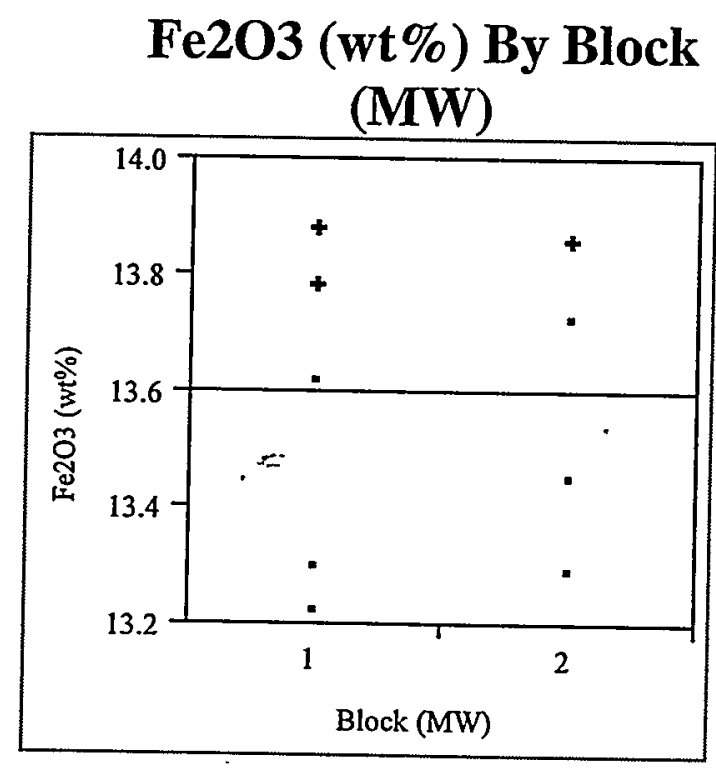

Li2O (wt\%) By Block (MW)

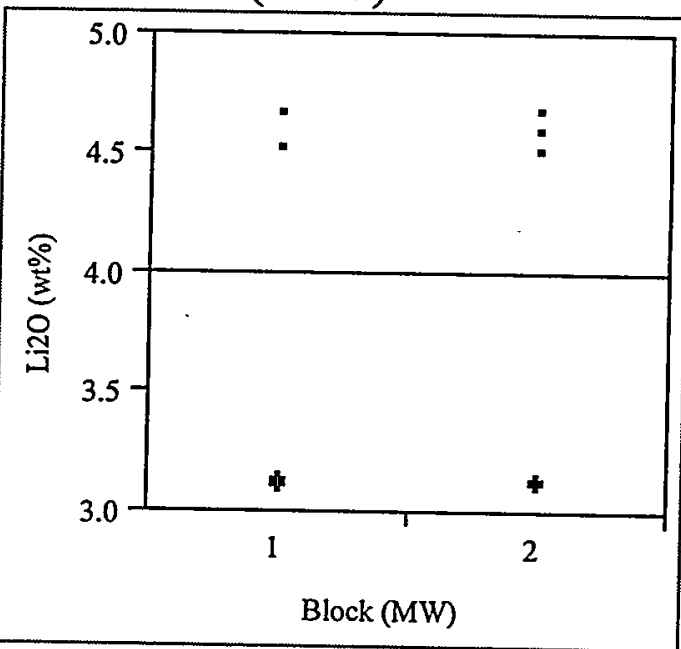

\section{MgO (wt\%) By Block}

(MW)

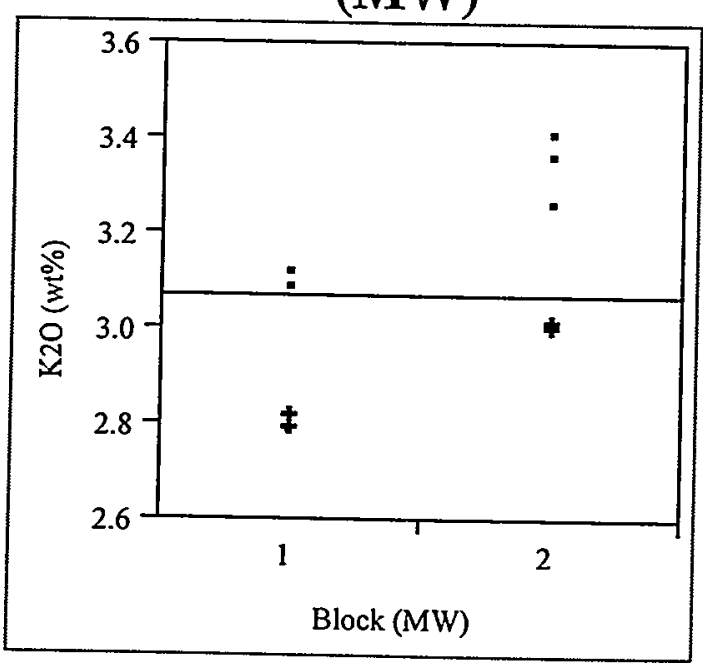

(MW)

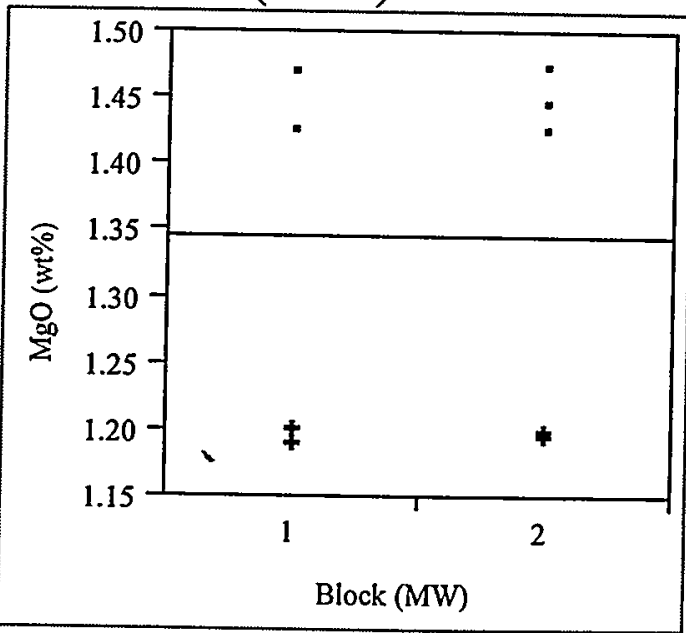


Exhibit A.3: Measurements of Glass Standards by Oxide (+ u-std; small square Batch 1 standard) (continued)

MnO (wt \%) By Block (MW)

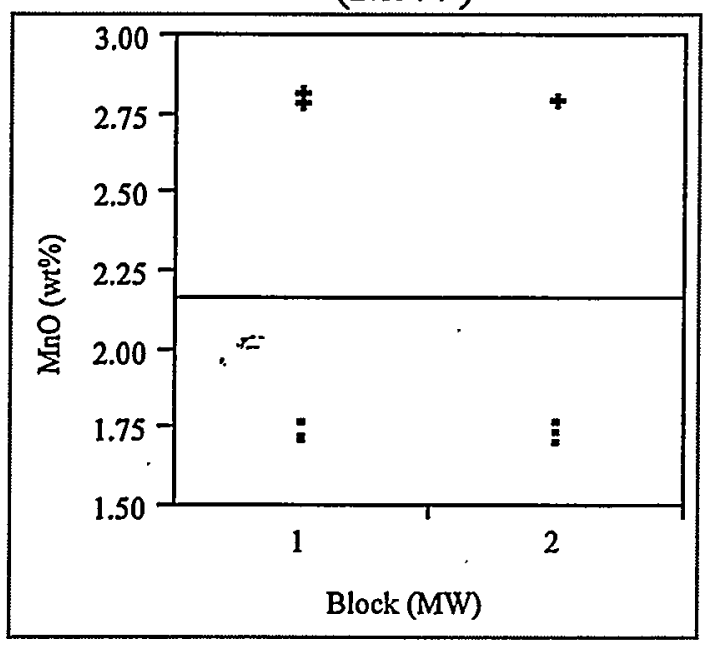

Na2O (wt\%) By Block (MW)

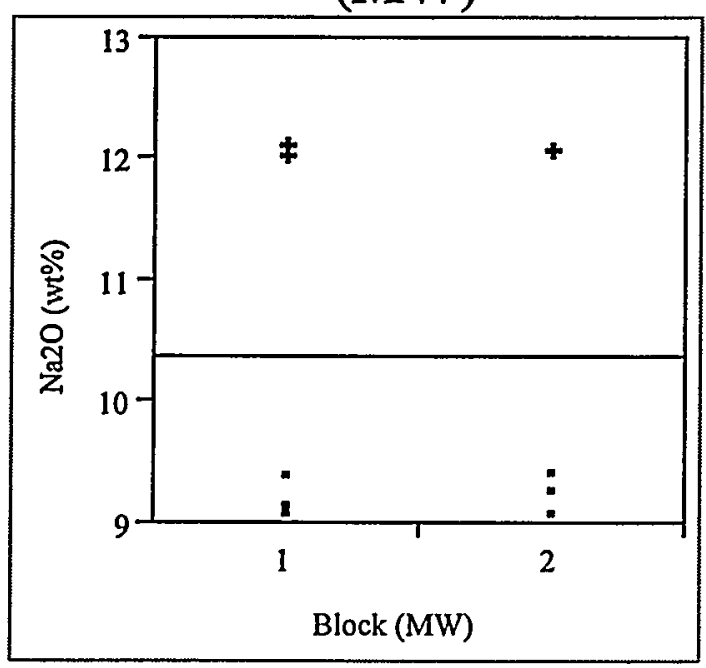

Nb2O5 (wt\%) By Block

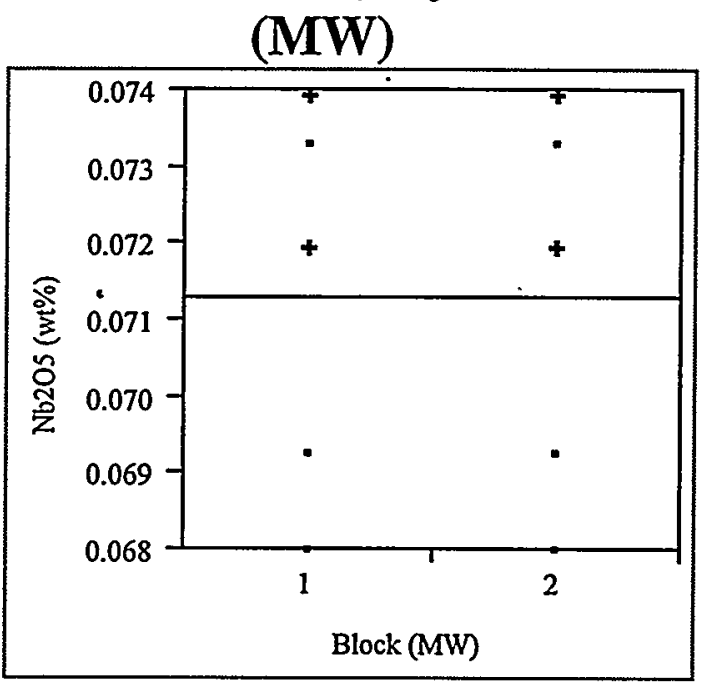

NiO (wt\%) By Block (MW)

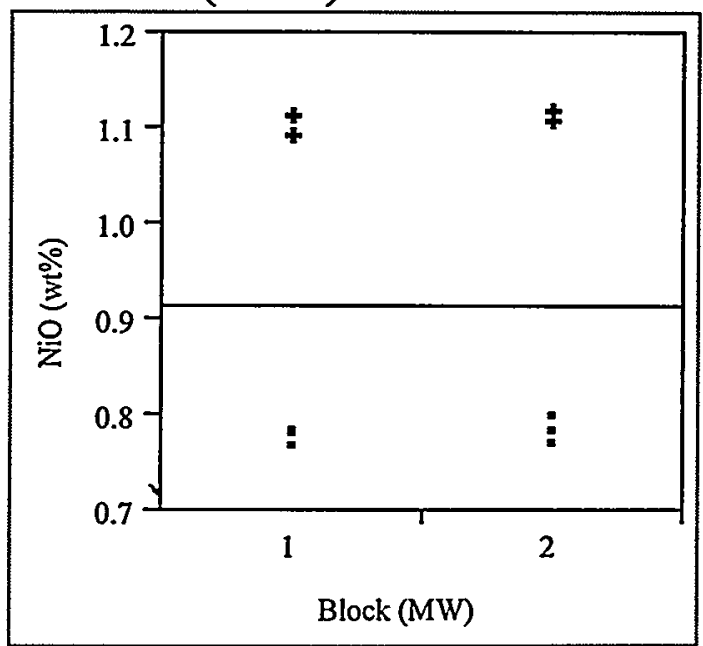


Exhibit A.3: Measurements of Glass Standards by Oxide

(+ U-std; small square Batch 1 standard) (continued)

$\mathrm{SiO} 2 \mathrm{MW}(\mathrm{wt} \%)$ By Block (MW)

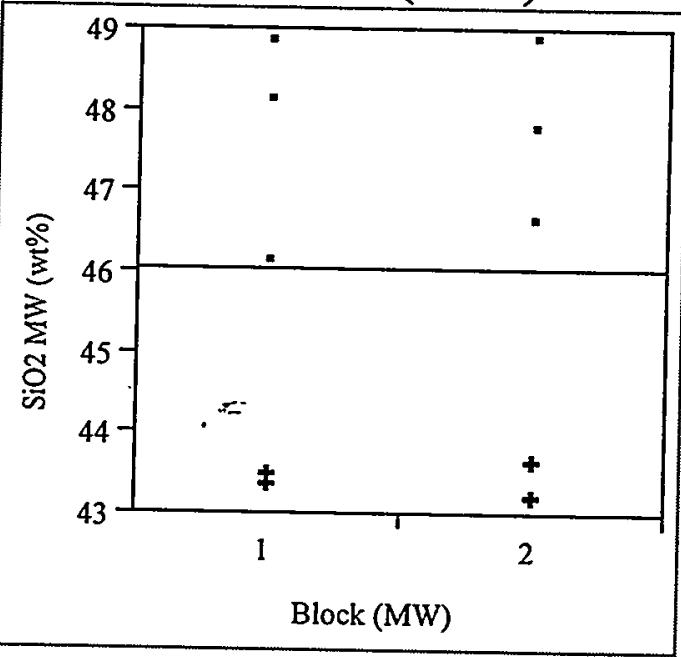

TiO2 (wt\%) By Block (MW)

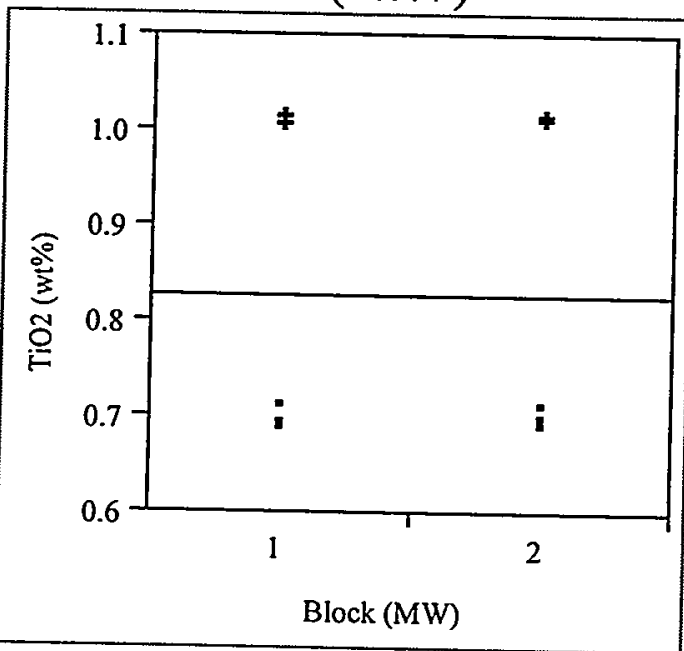

\section{U308 (wt\%) By Block}

(MW)

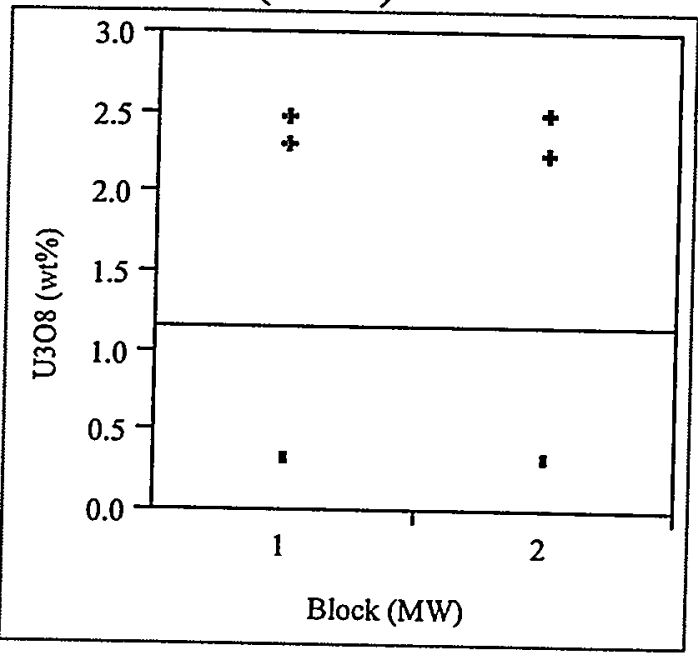

ZrO2 (wt\%) By Block (MW)

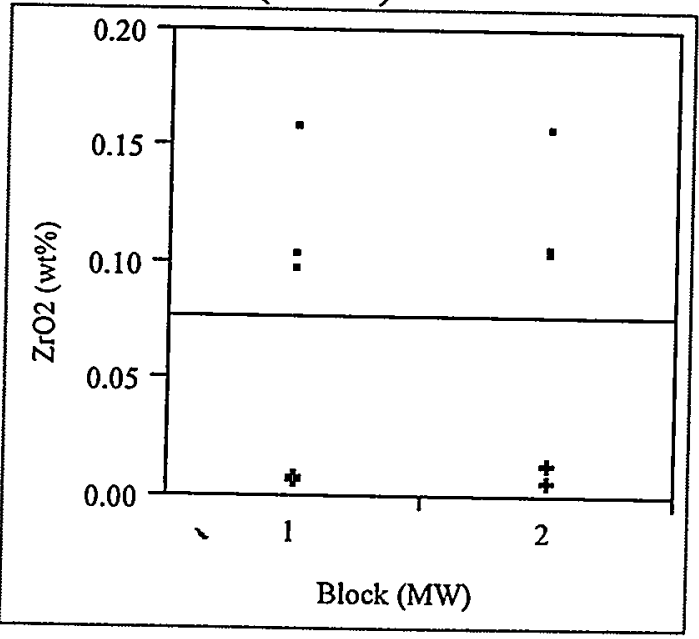


Exhibit A.4: Comparisons of Measurements versus Target Compositions

(concentrations in weight percents)

$\mathrm{Al203}$ i)

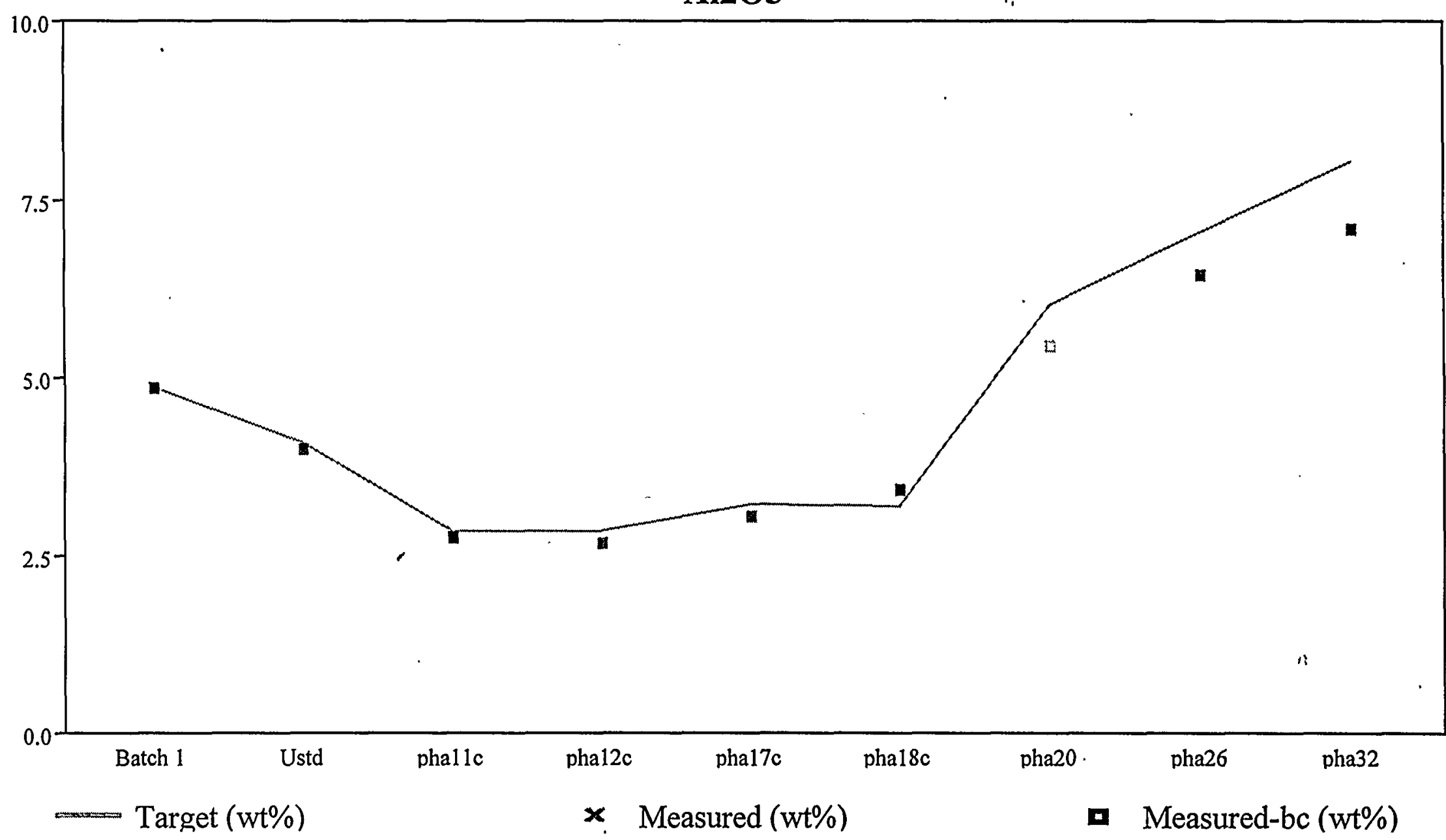


Exhibit A.4: Comparisons of Measurements versus Target Compositions (concentrations in weight percents)

$\mathrm{B2O3}$

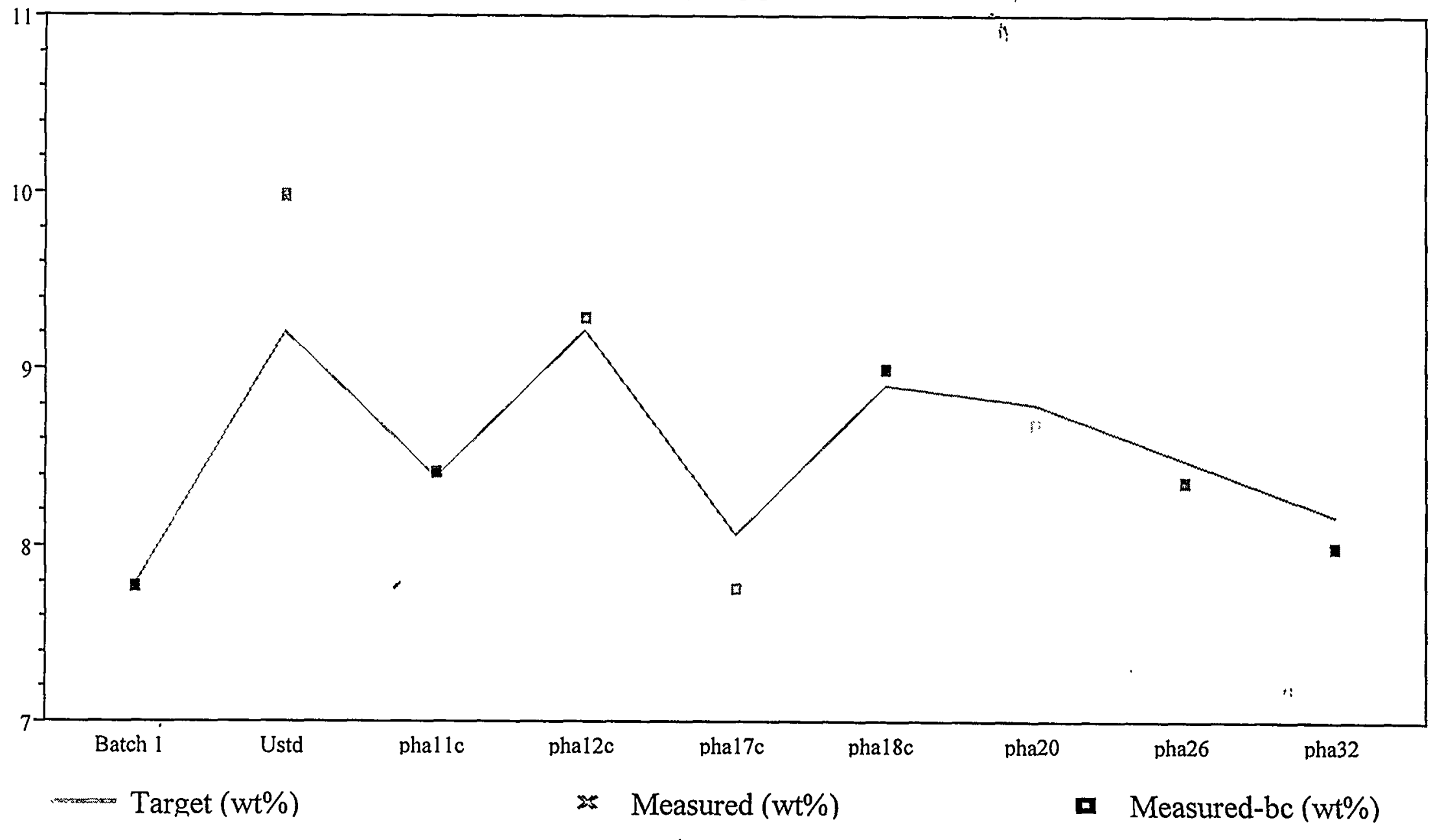


Exhibit A.4: Comparisons of Measurements versus Target Compositions (concentrations in weight percents)

$\mathrm{CaO}$

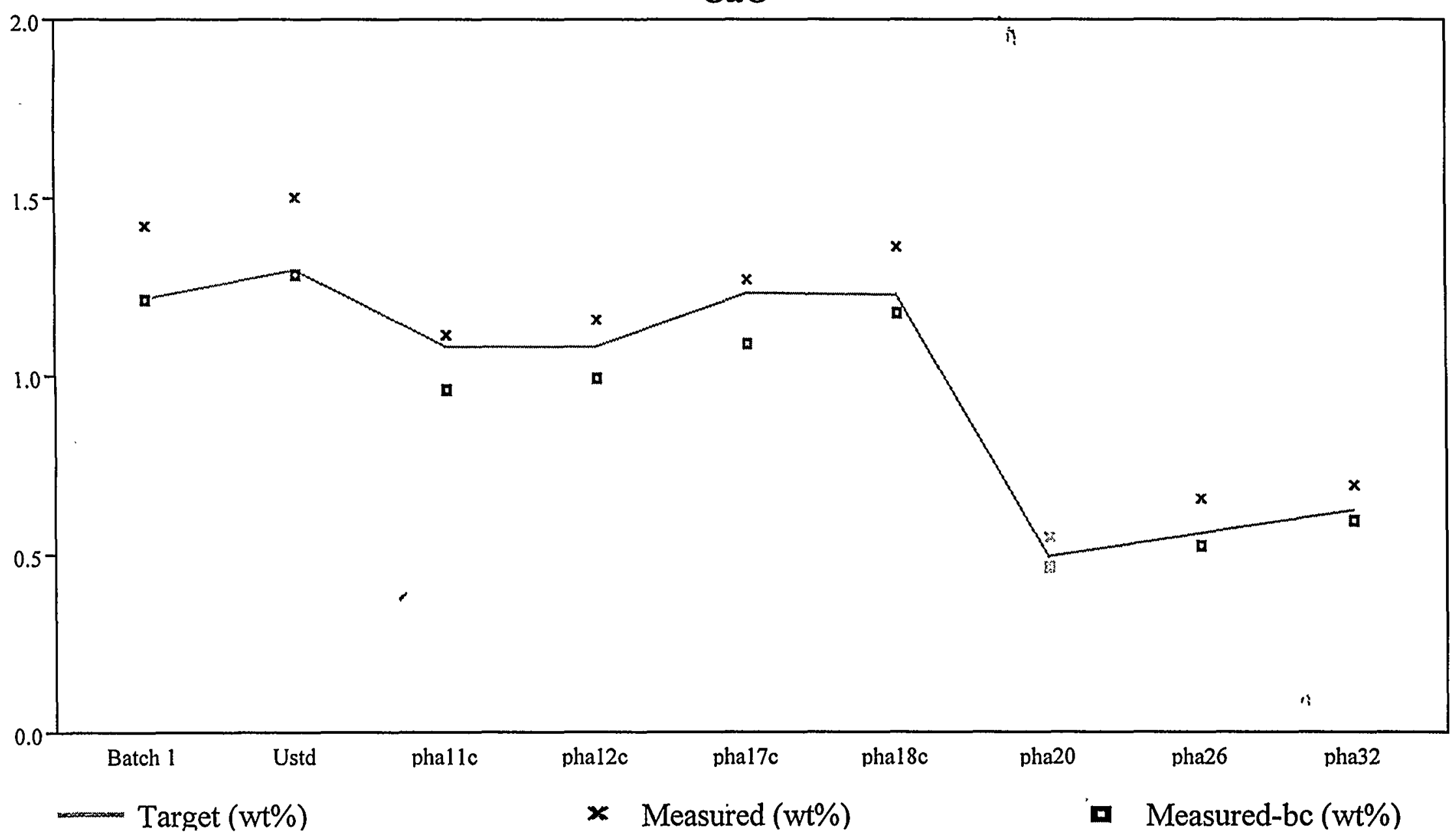


Exhibit A.4: Comparisons of Measurements versus Target Compositions

(concentrations in weight percents)

Cr2O3

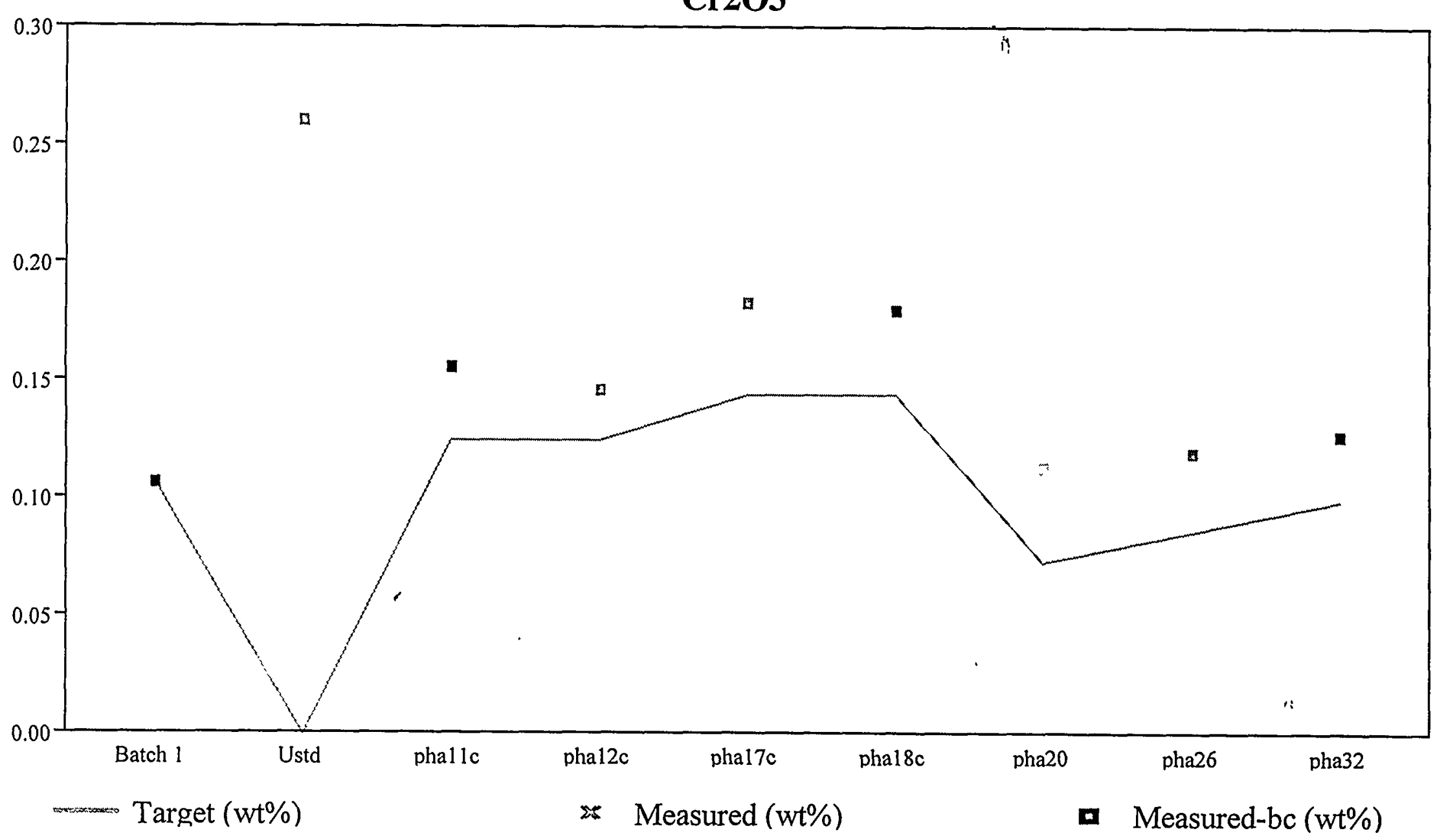


Exhibit A.4: Comparisons of Measurements versus Target Compositions

(concentrations in weight percents)

$\mathrm{CuO}$

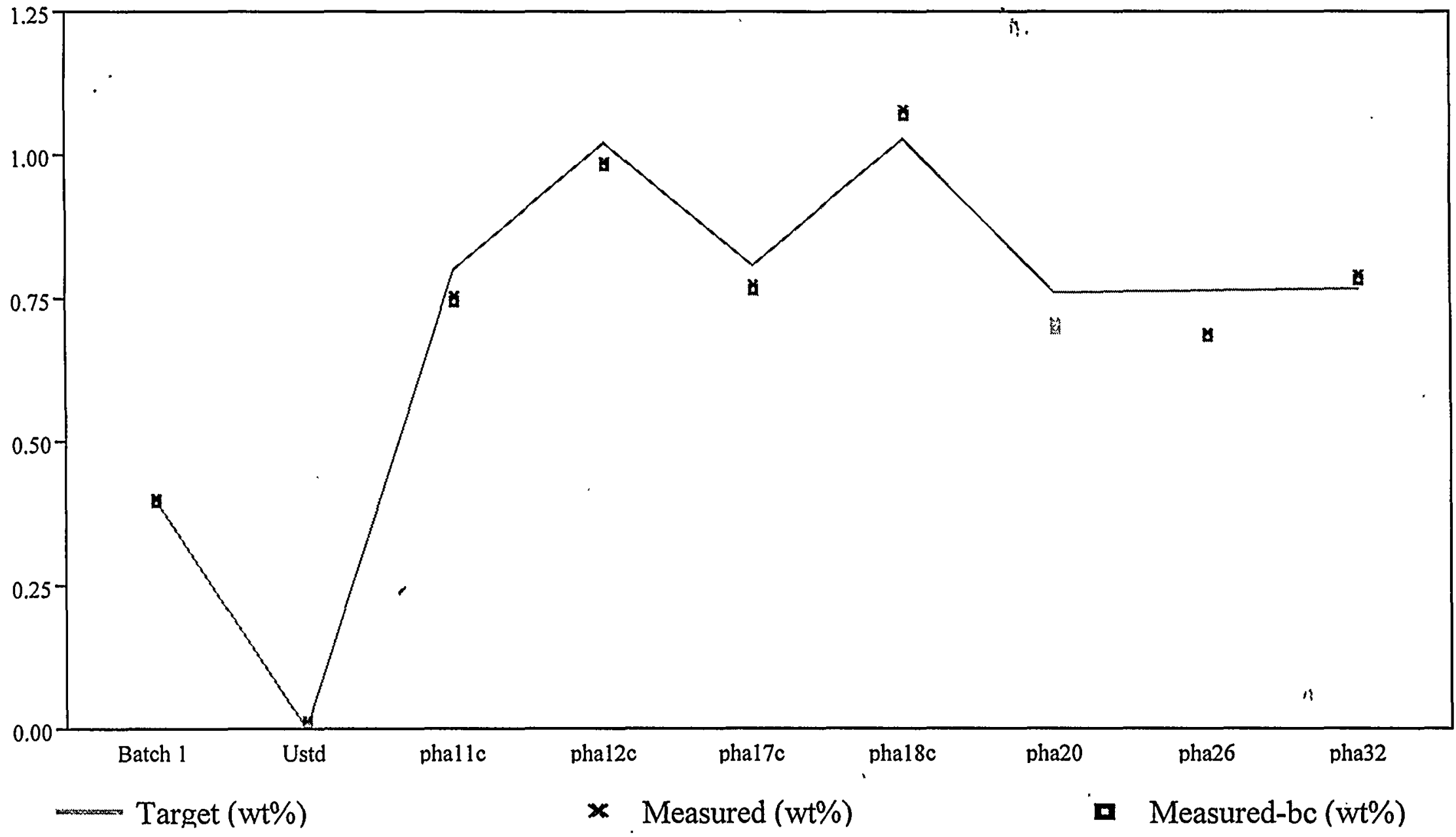


Exhibit A.4: Comparisons of Measurements versus Target Compositions

(concentrations in weight percents)

$\mathrm{Fe} 2 \mathrm{O3}$

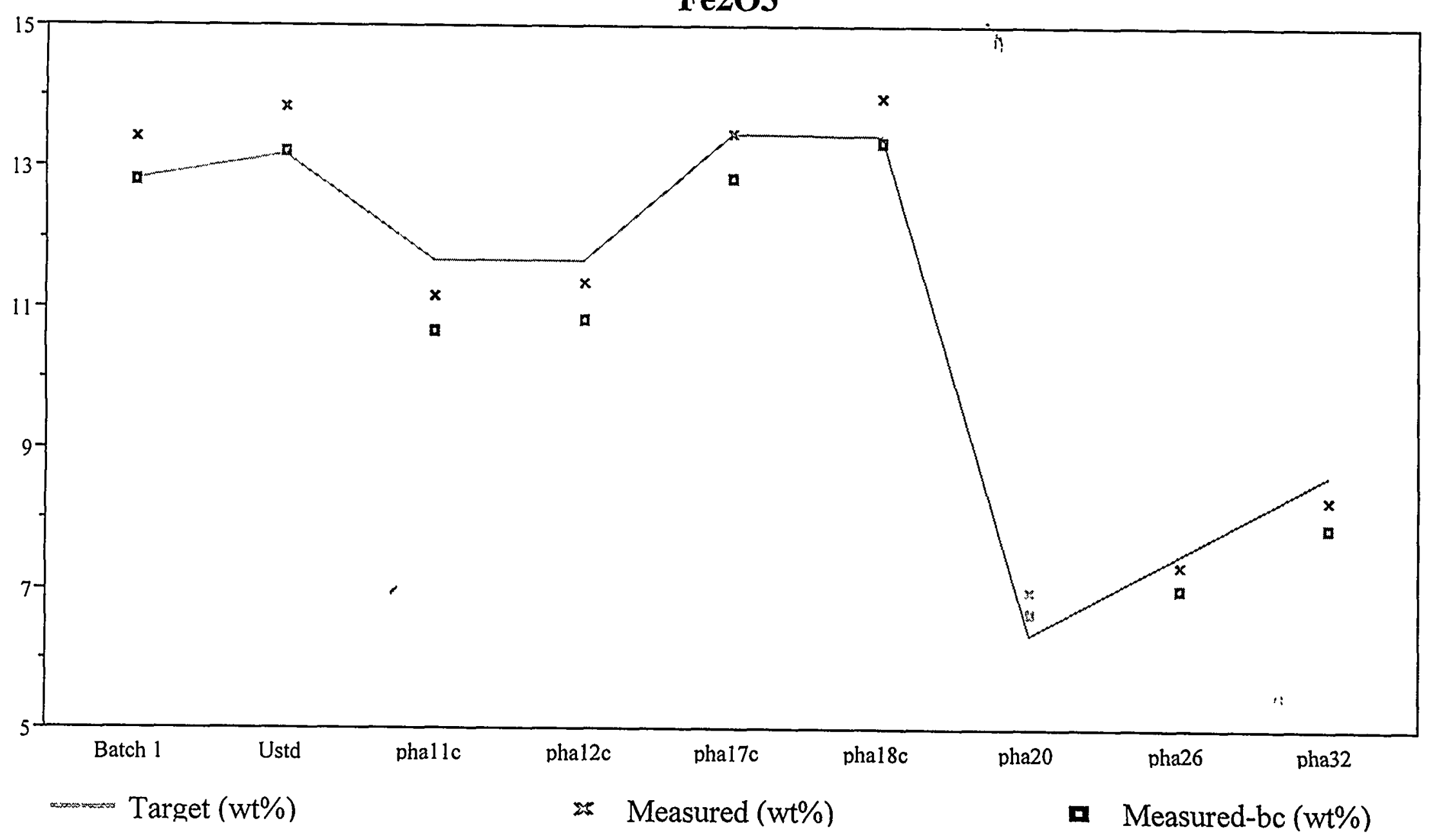



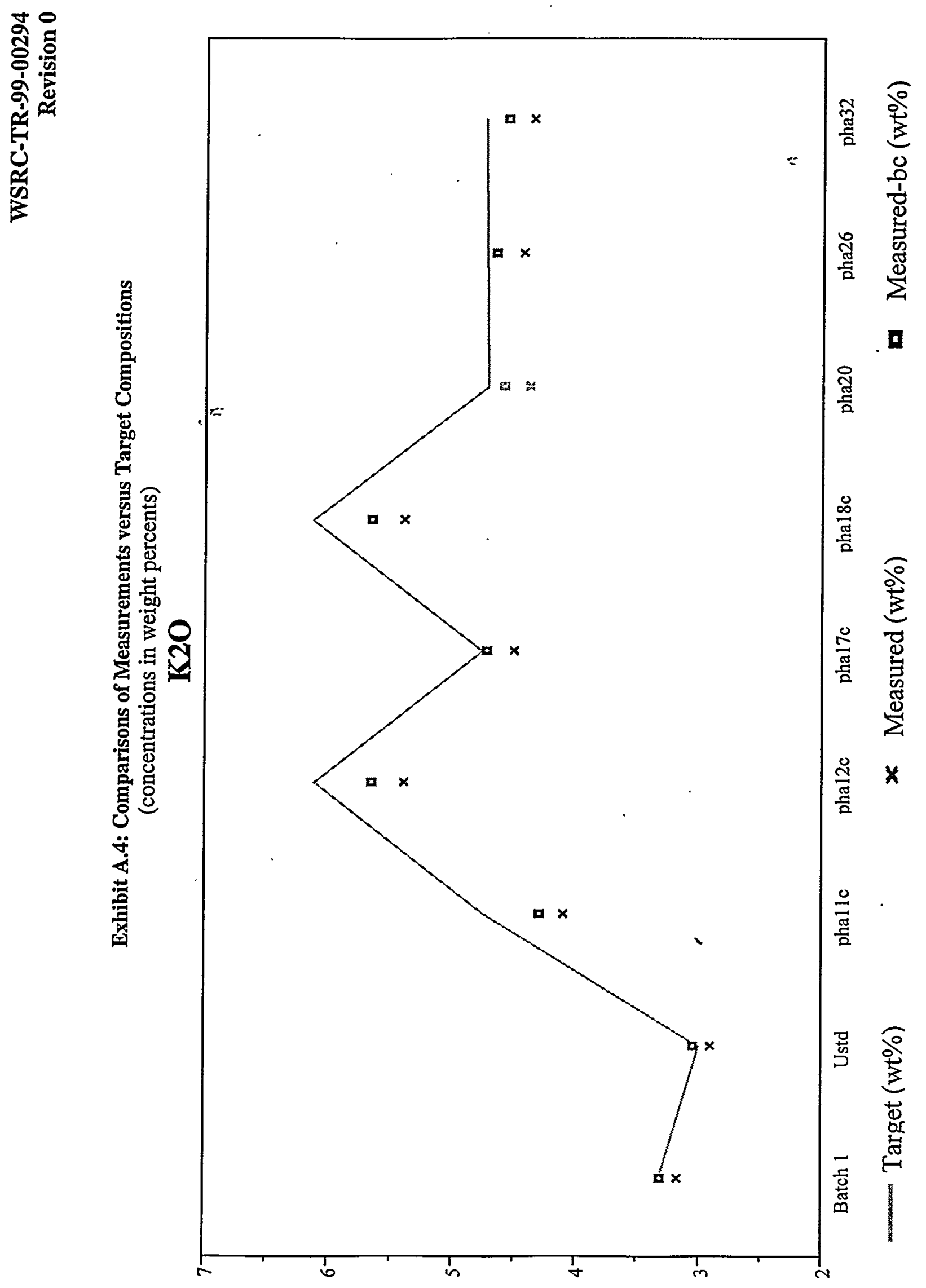
Exhibit A.4: Comparisons of Measurements versus Target Compositions (concentrations in weight percents)

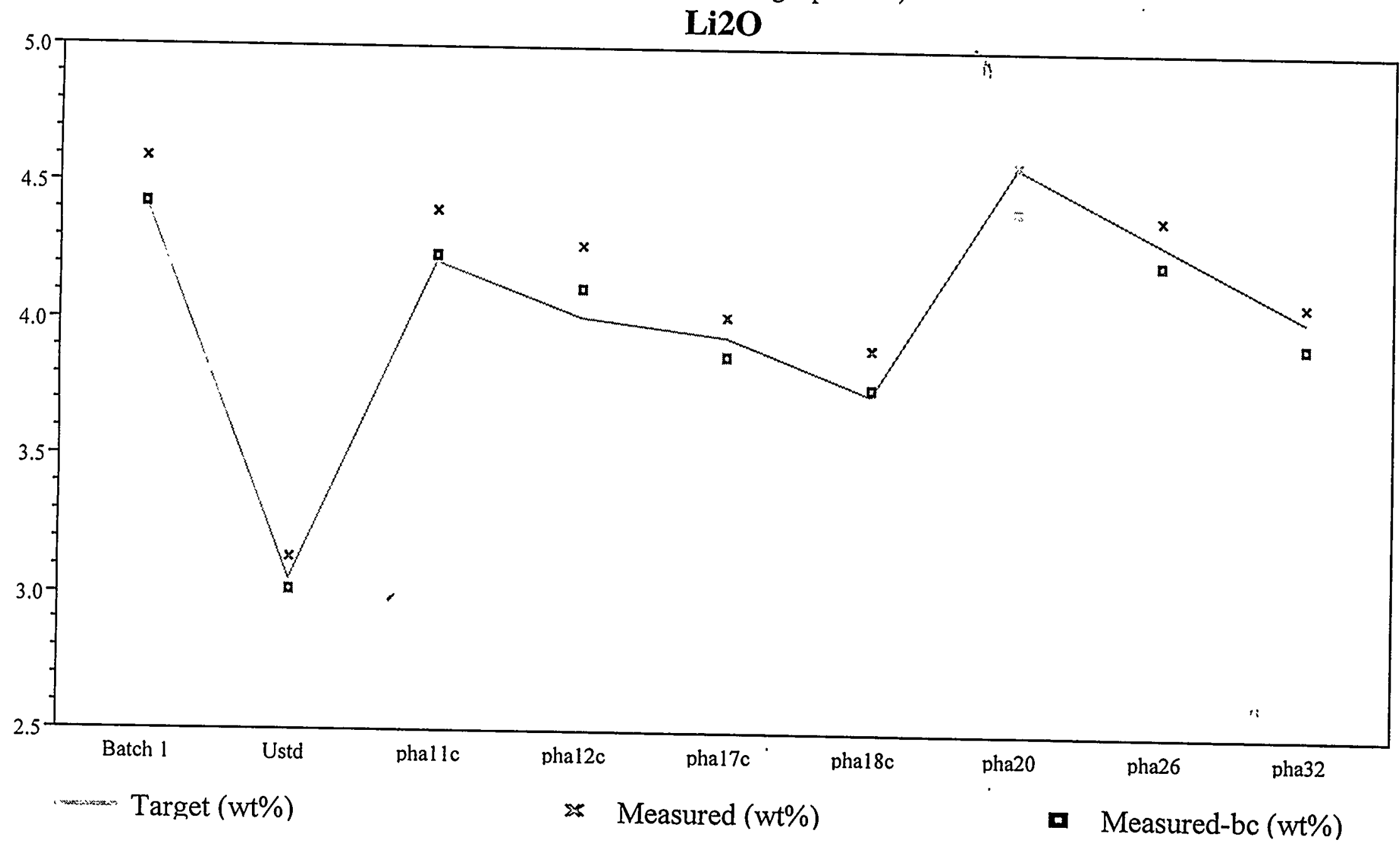


Exhibit A.4: Comparisons of Measurements versus Target Compositions (concentrations in weight percents)

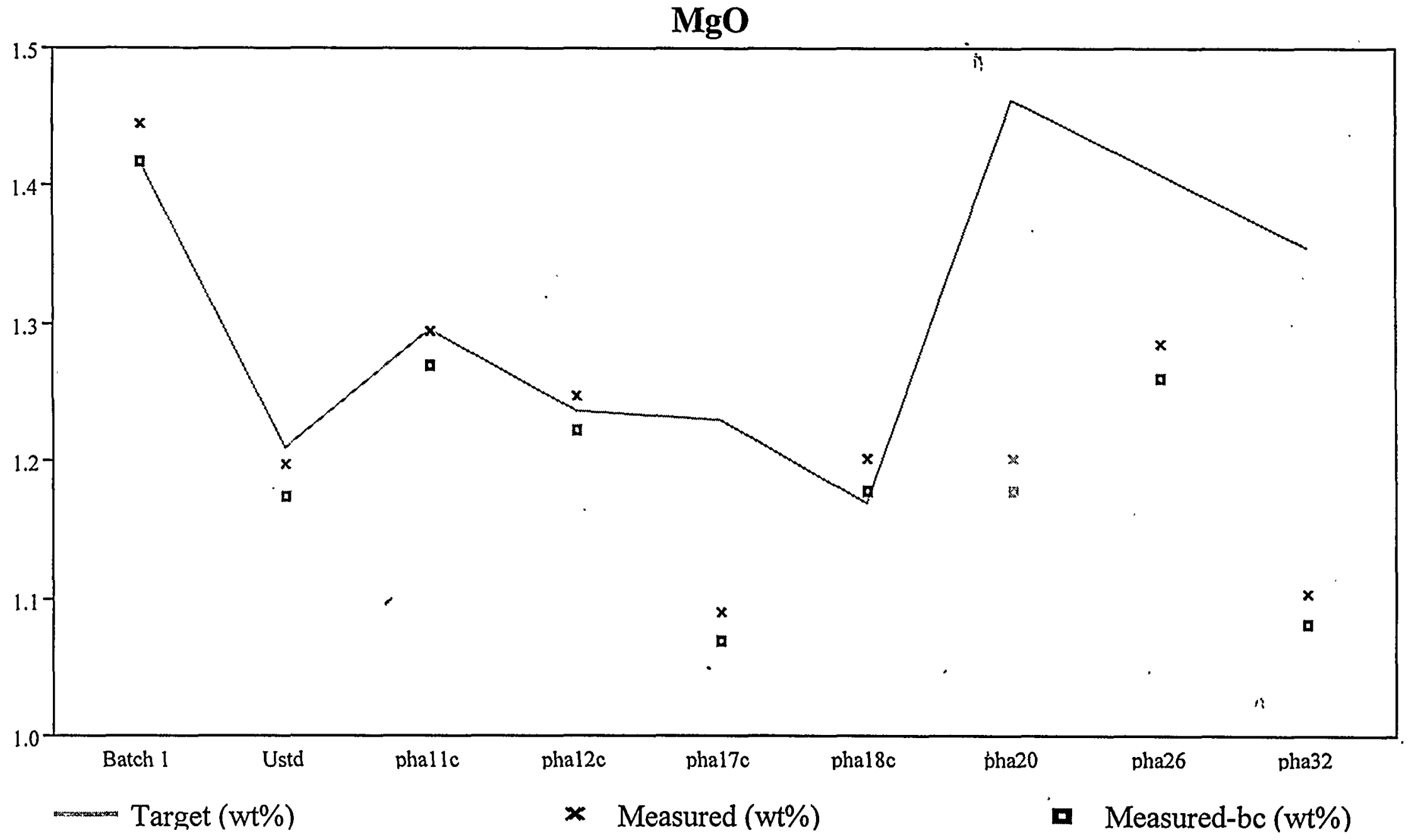


Exhibit A.4: Comparisons of Measurements versus Target Compositions

(concentrations in weight percents)

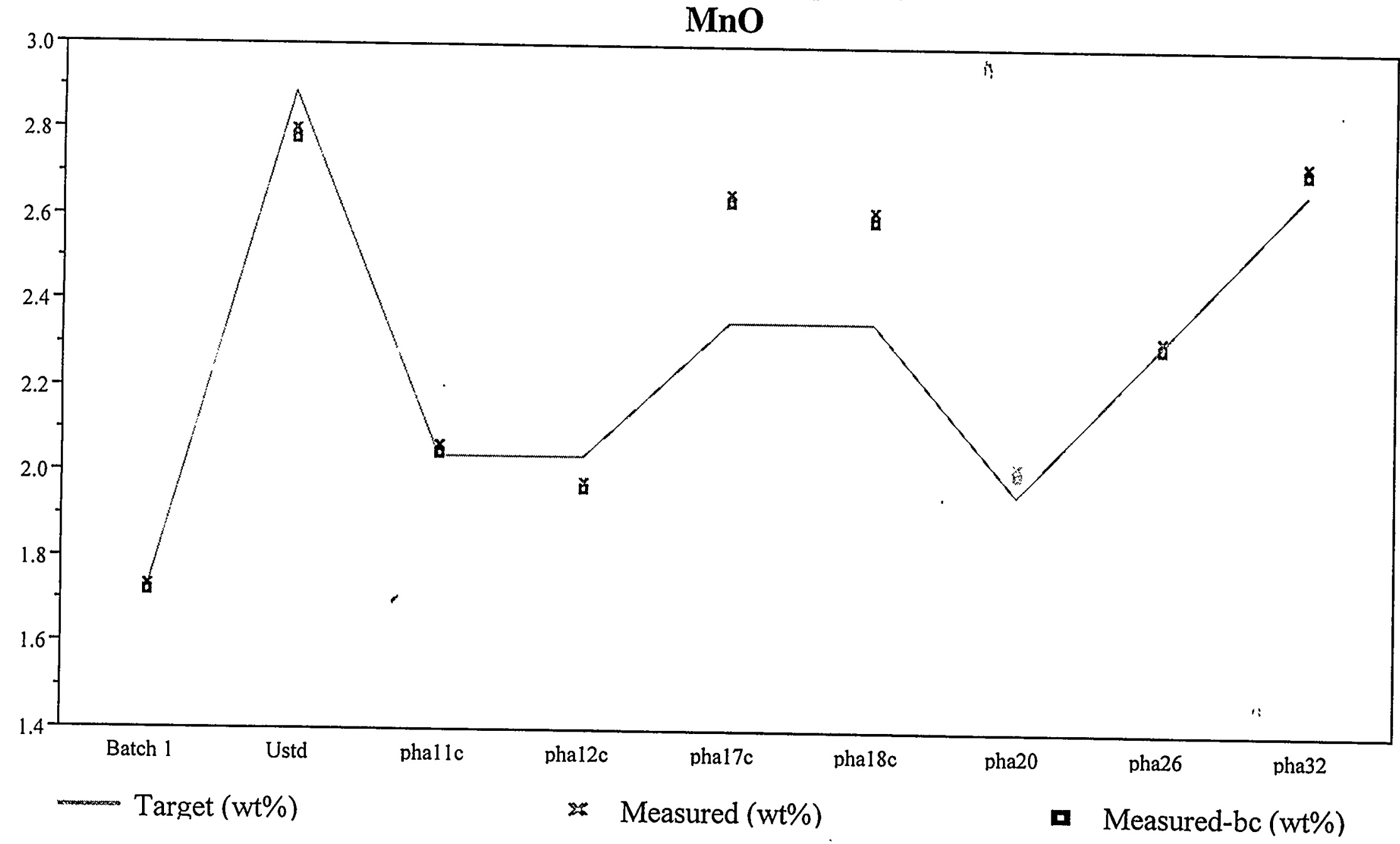


Exhibit A.4: Comparisons of Measurements versus Target Compositions

(concentrations in weight percents)

$\mathrm{Na} 2 \mathrm{O}$

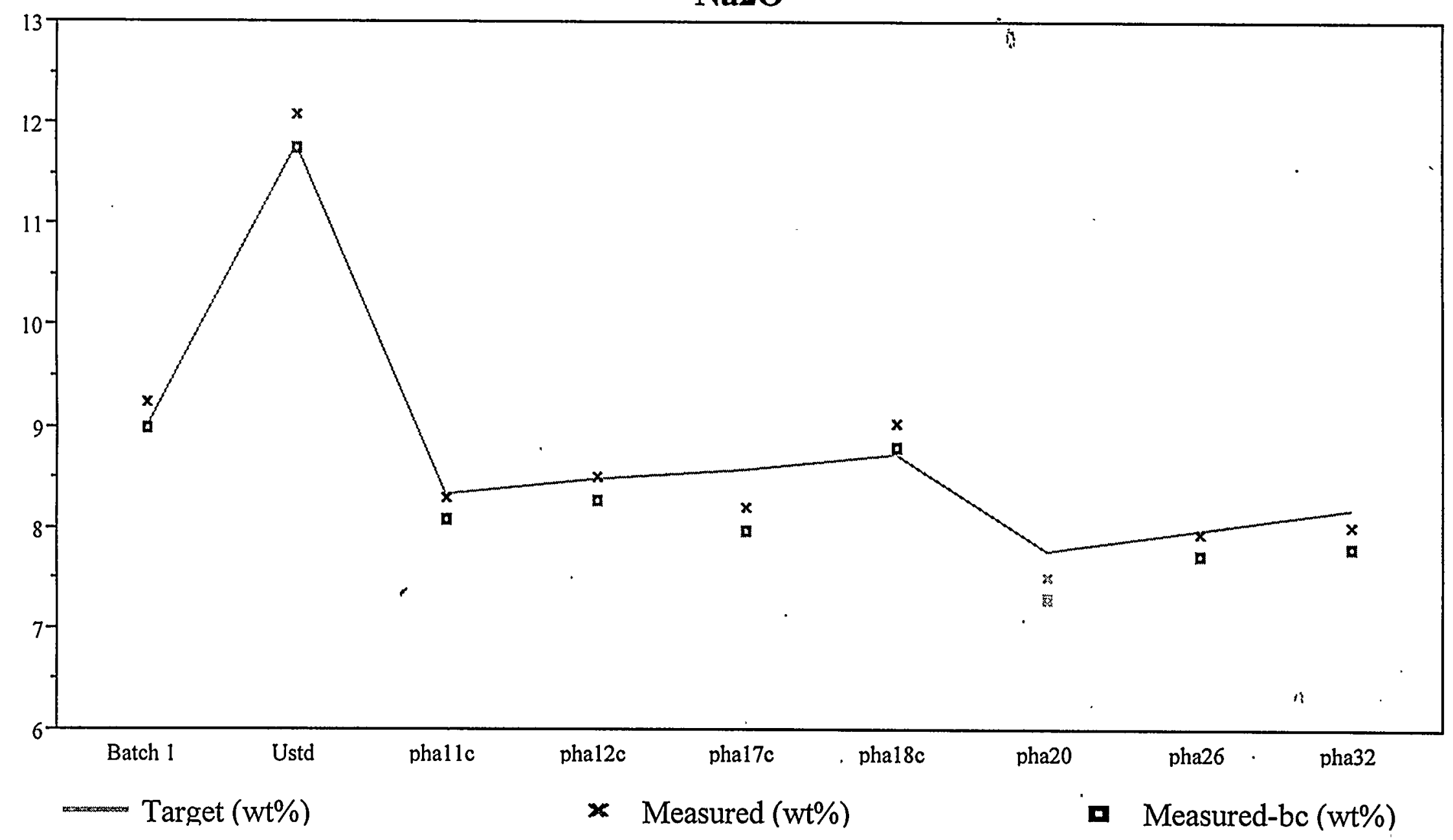


Exhibit A.4: Comparisons of Measurements versus Target Compositions (concentrations in weight percents)

$\mathrm{NiO}$

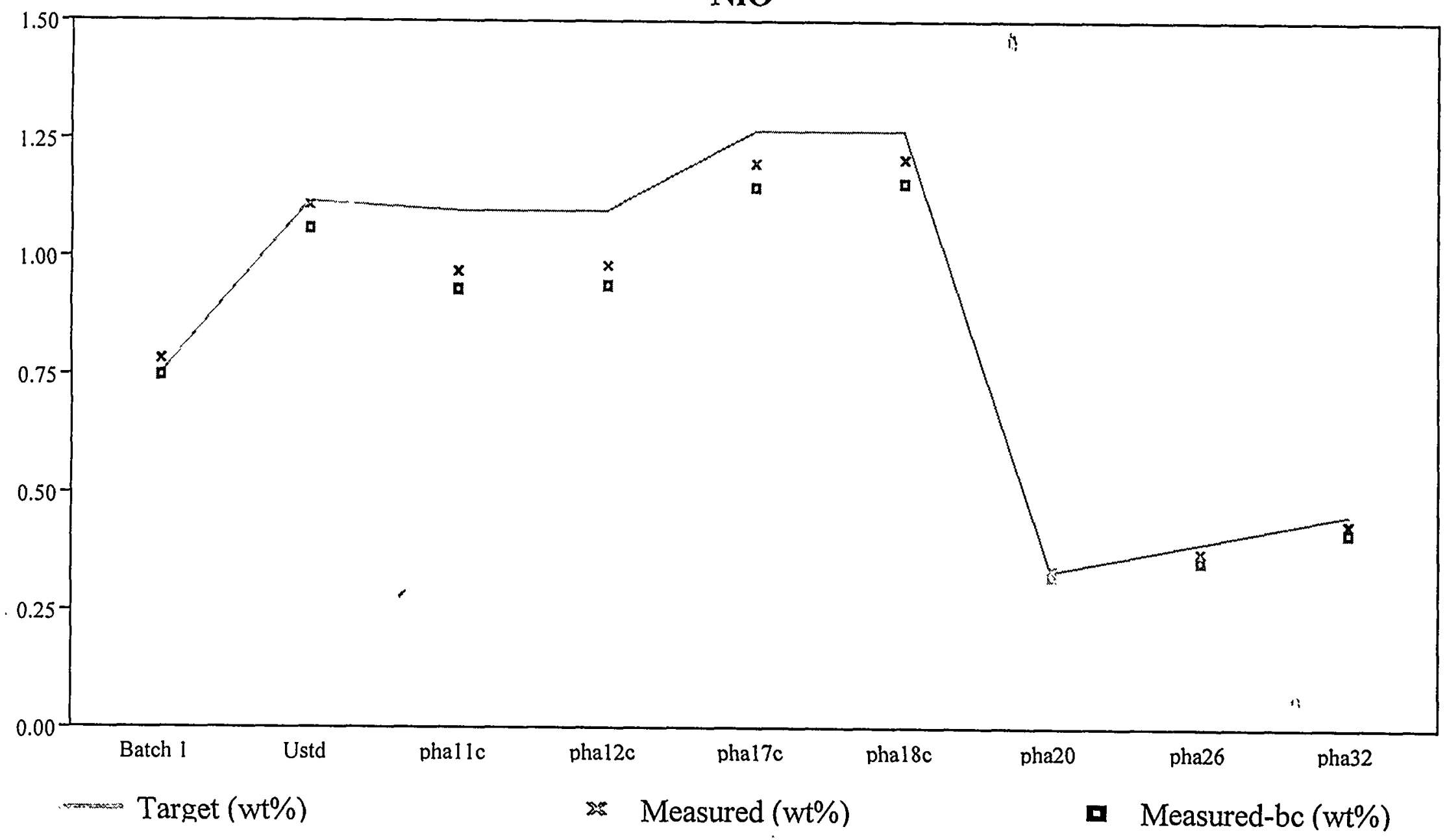


Exhibit A.4: Comparisons of Measurements versus Target Compositions (concentrations in weight percents)

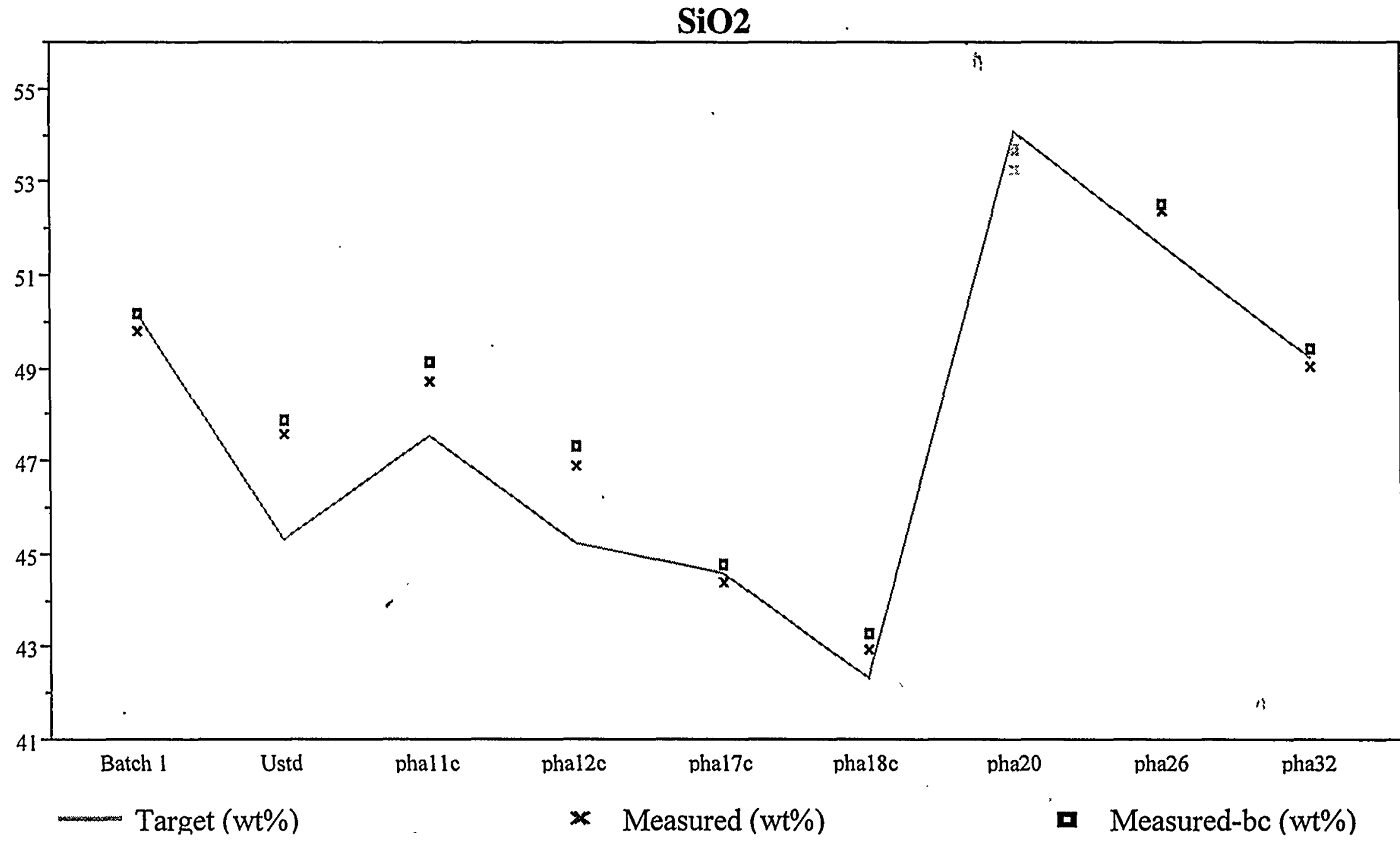


Exhibit A.4: Comparisons of Measurements versus Target Compositions (concentrations in weight percents)

$\mathrm{TiO} 2$

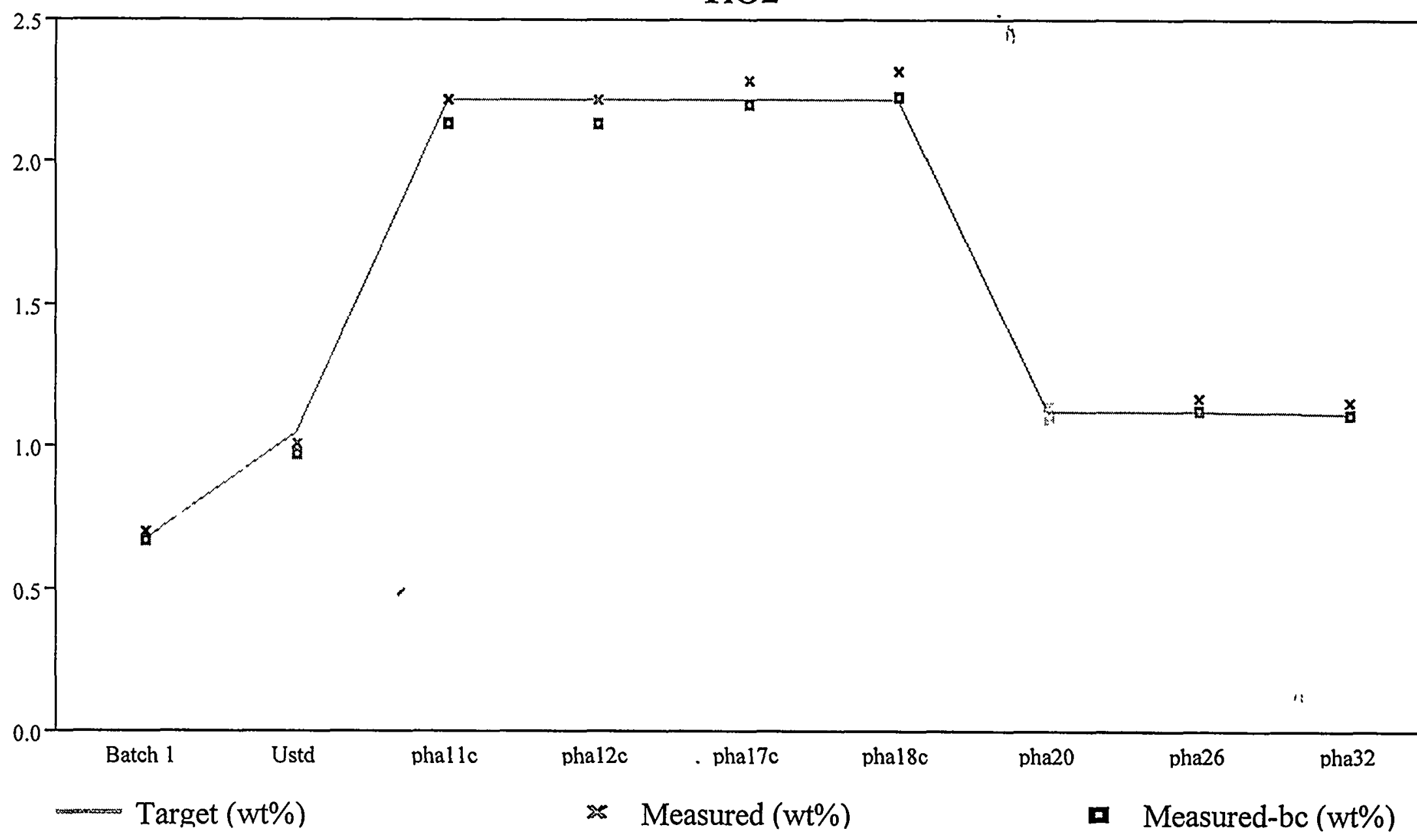


Exhibit A.4: Comparisons of Measurements versus Target Compositions

(concentrations in weight percents)

U308

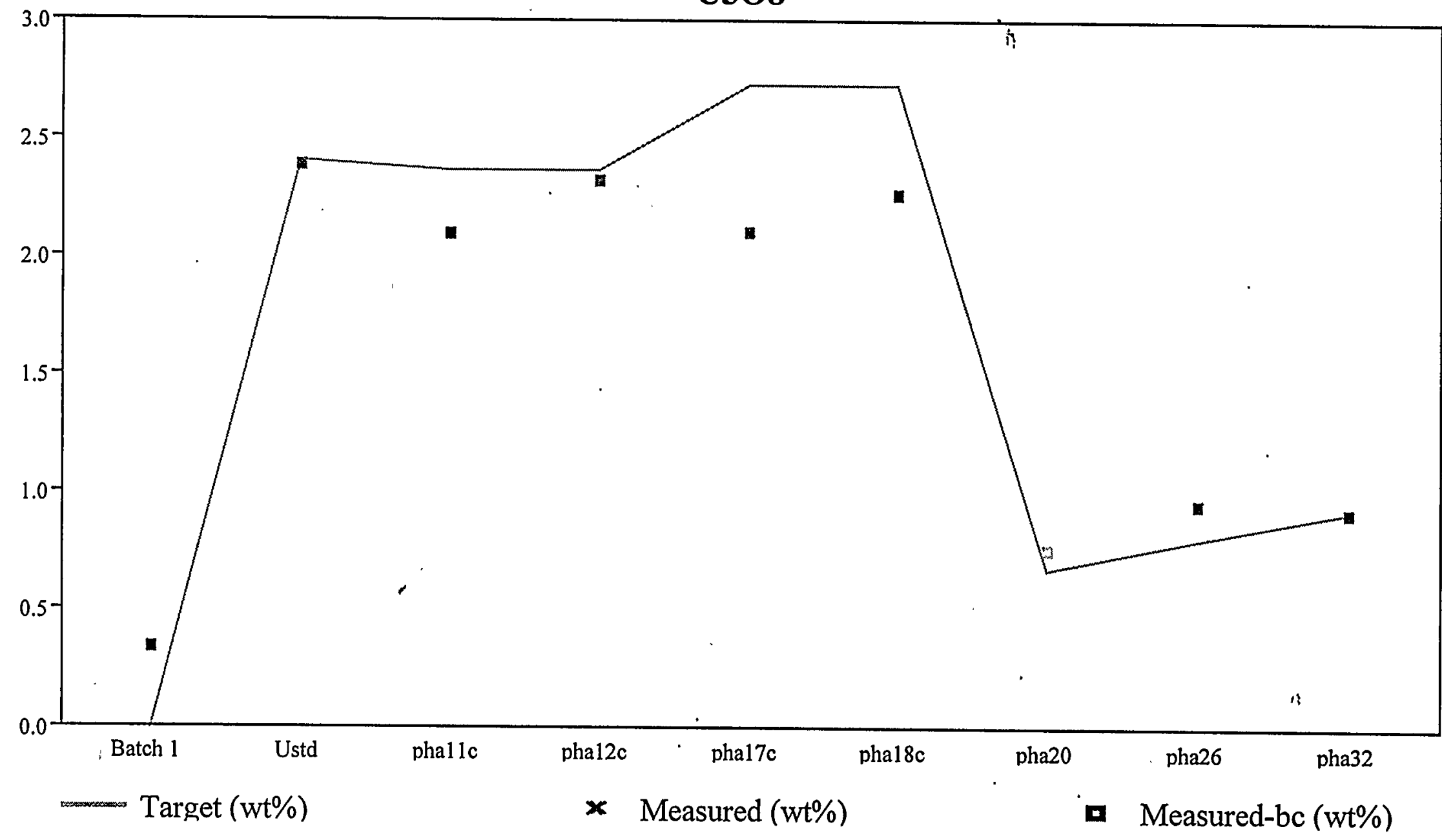


Exhibit A.4: Comparisons of Measurements versus Target Compositions

(concentrations in weight percents)

$\mathrm{ZrO2}$

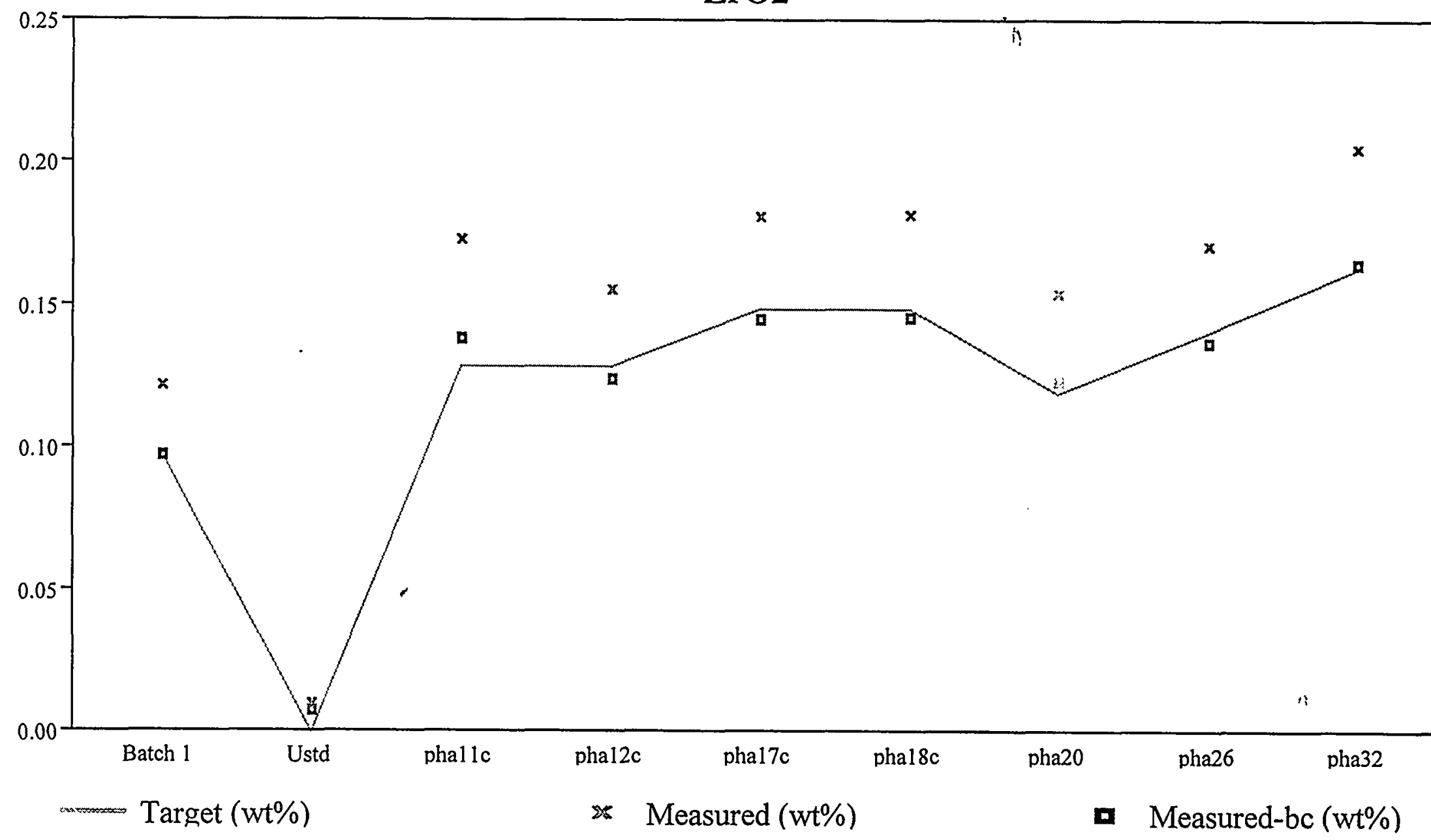


Exhibit A.4: Comparisons of Measurements versus Target Compositions

(concentrations in weight percents)

Sum of Oxides

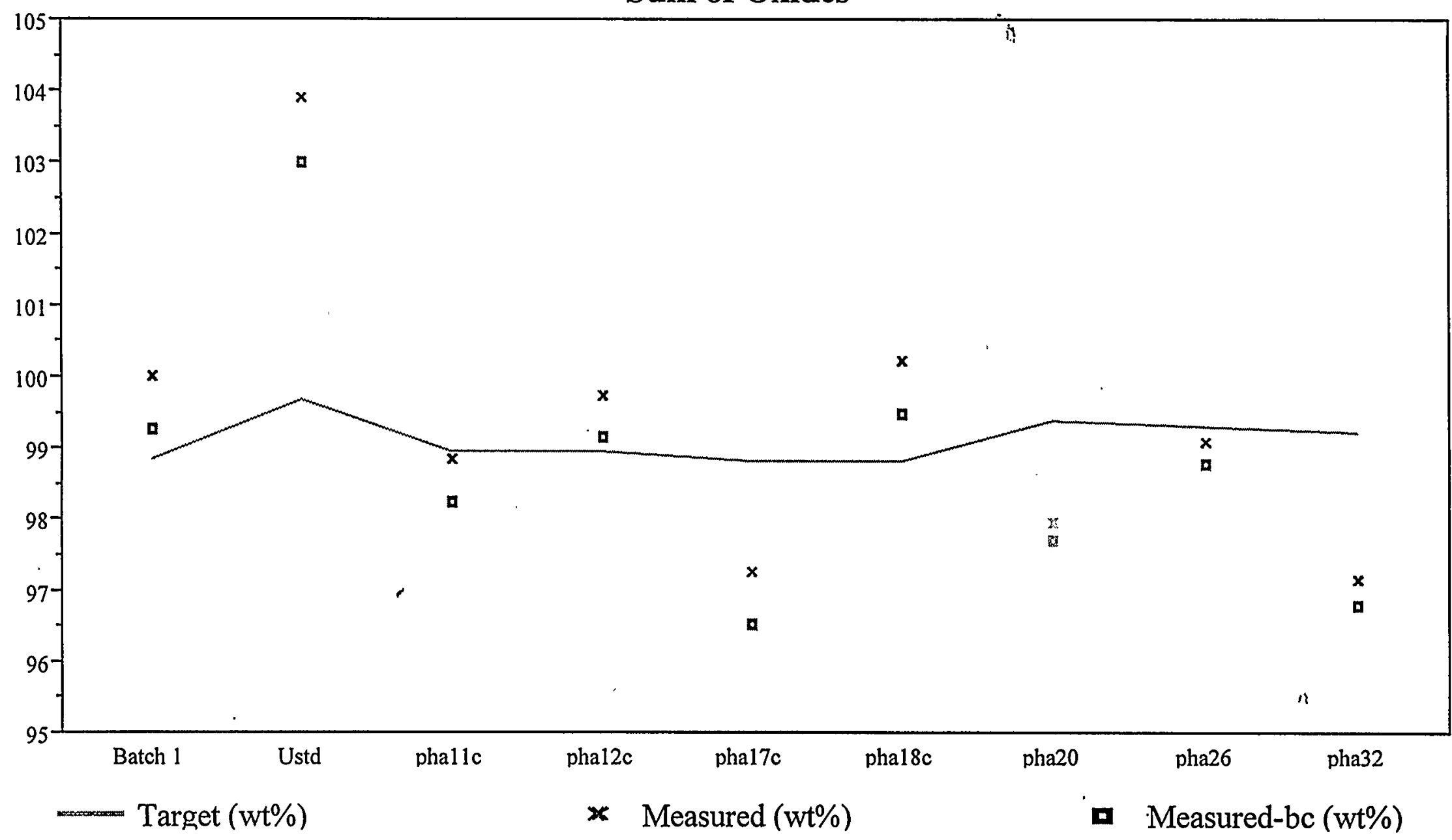


Exhibit A.5: Plots of the Leachate Concentrations by Sample ID by Element (with and without the EA and blank samples)

B (ppm) By Sample ID
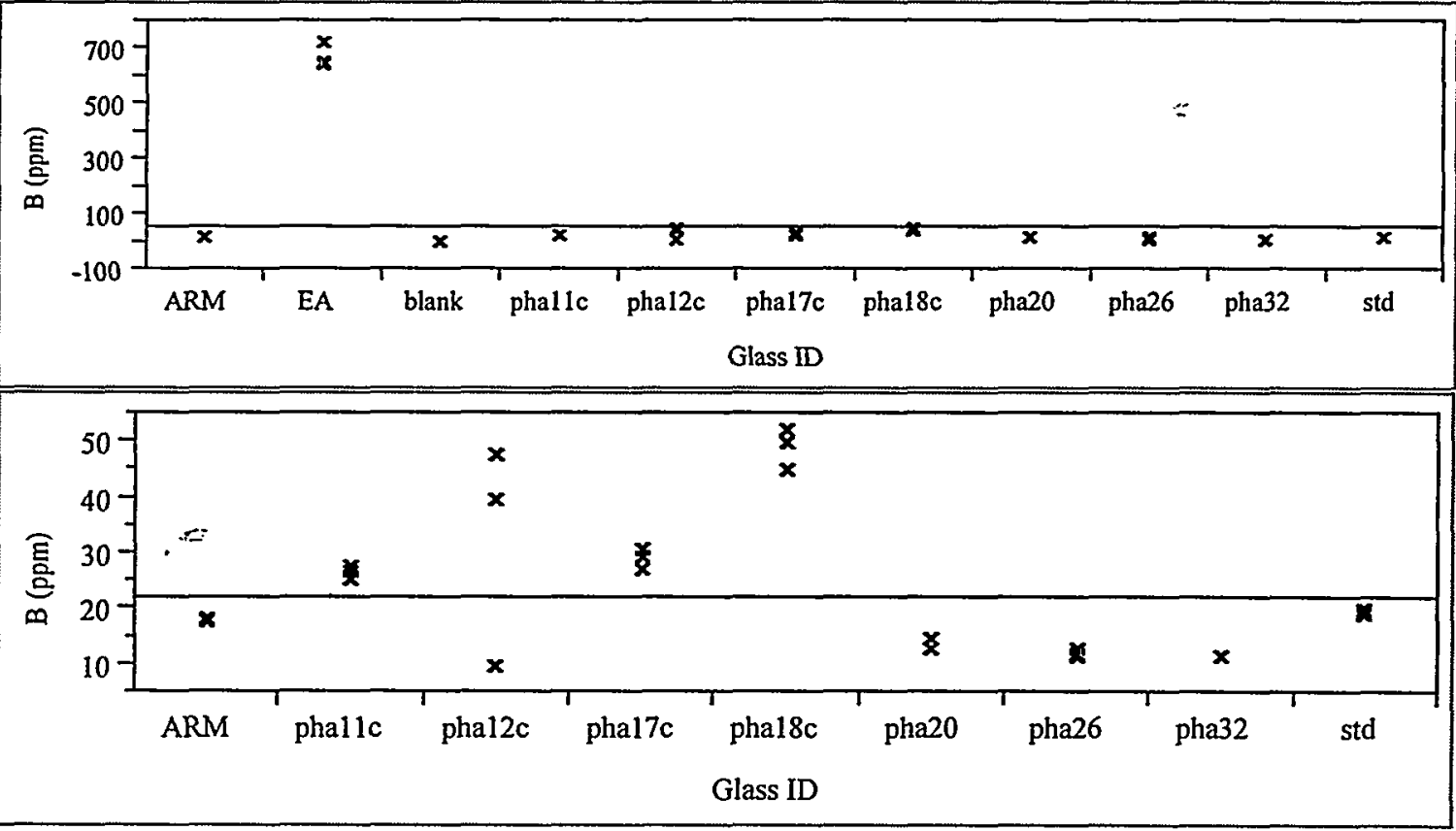

Si (ppm) By Sample ID
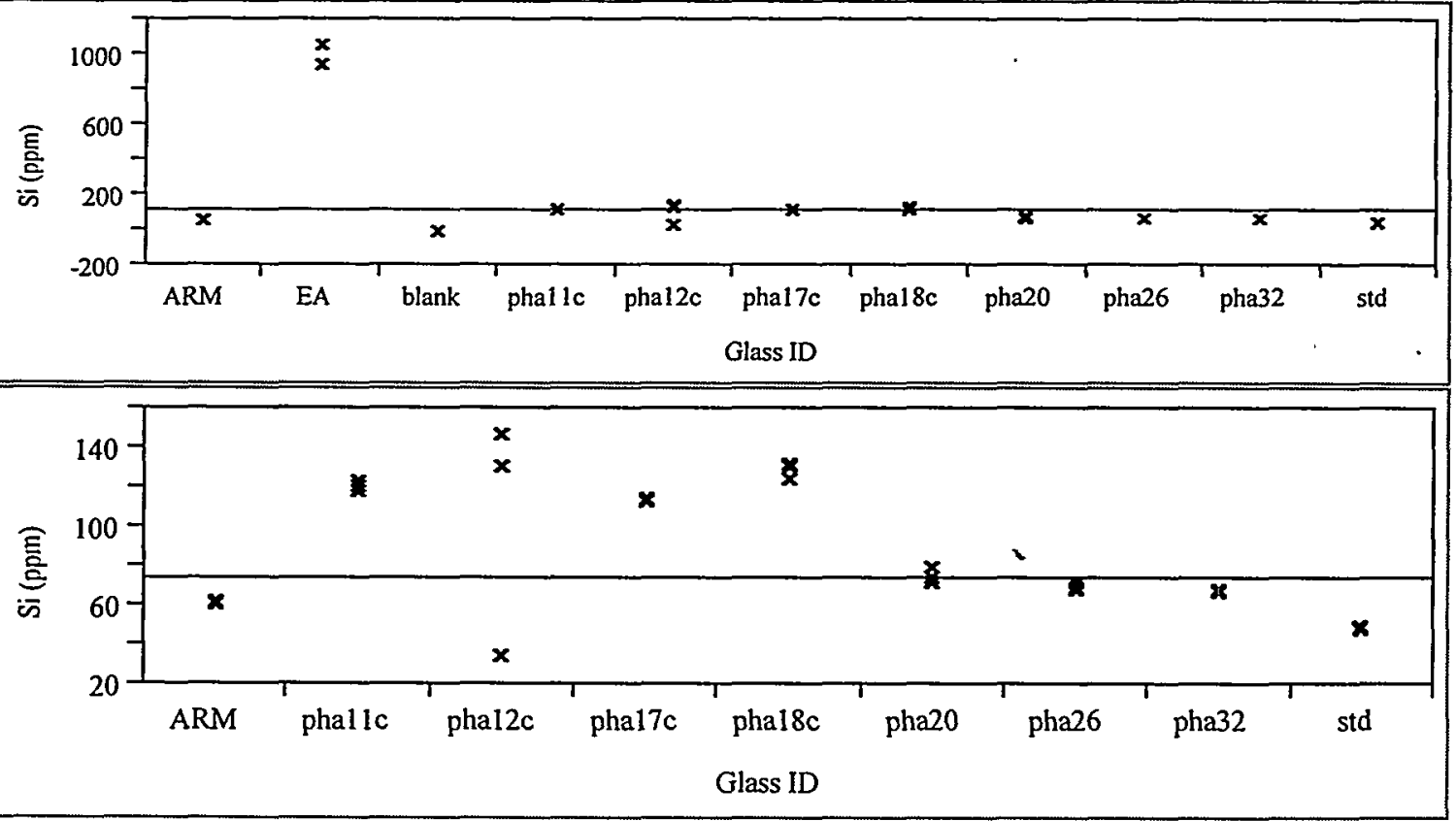
Exhibit A.5: Plots of the Leachate Concentrations by Sample $\mathbf{W}$ by Element (with and without the EA and blank samples) (continued)

Na (ppm) By Sample ID
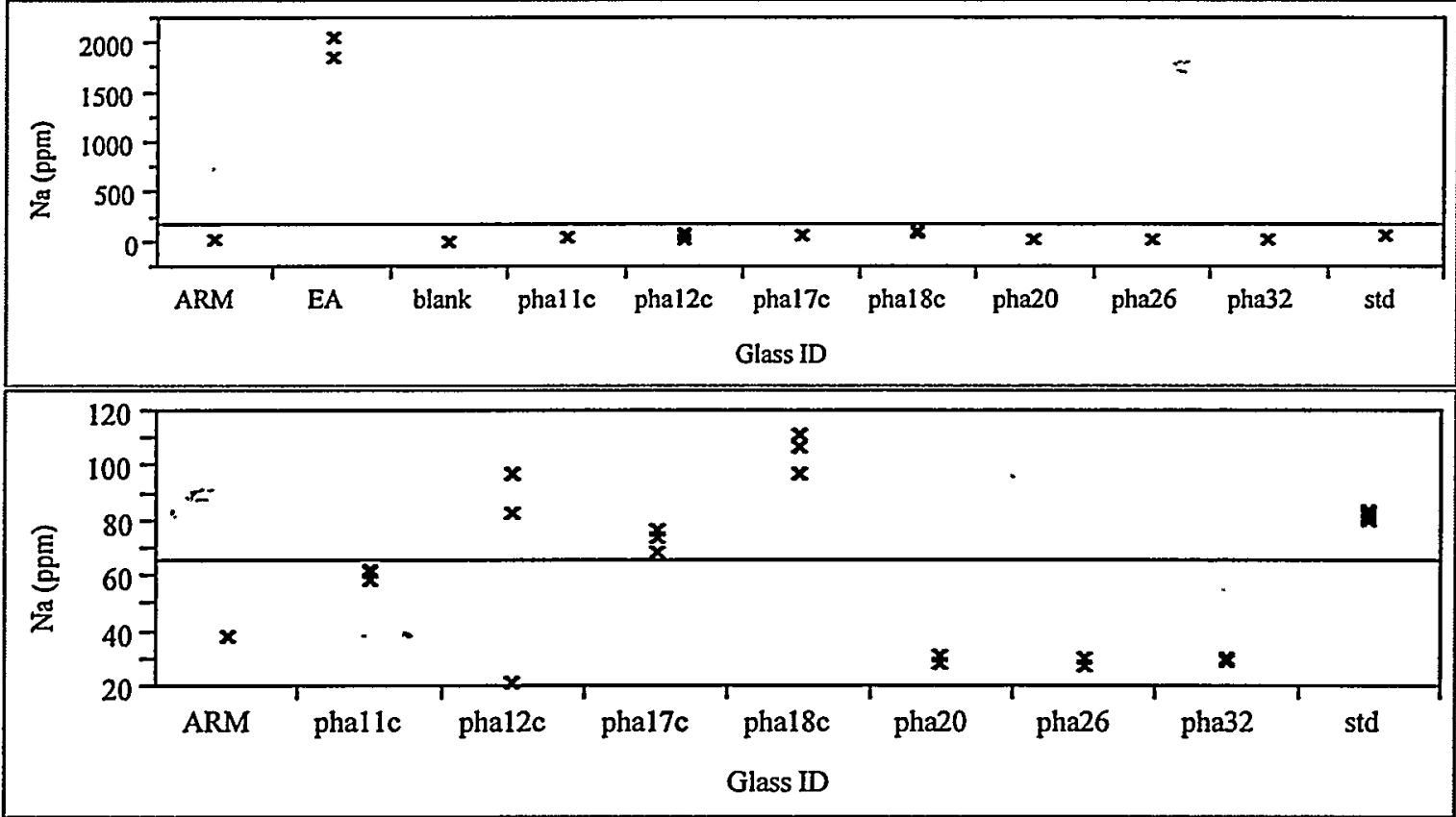

Li (ppm) By Sample ID
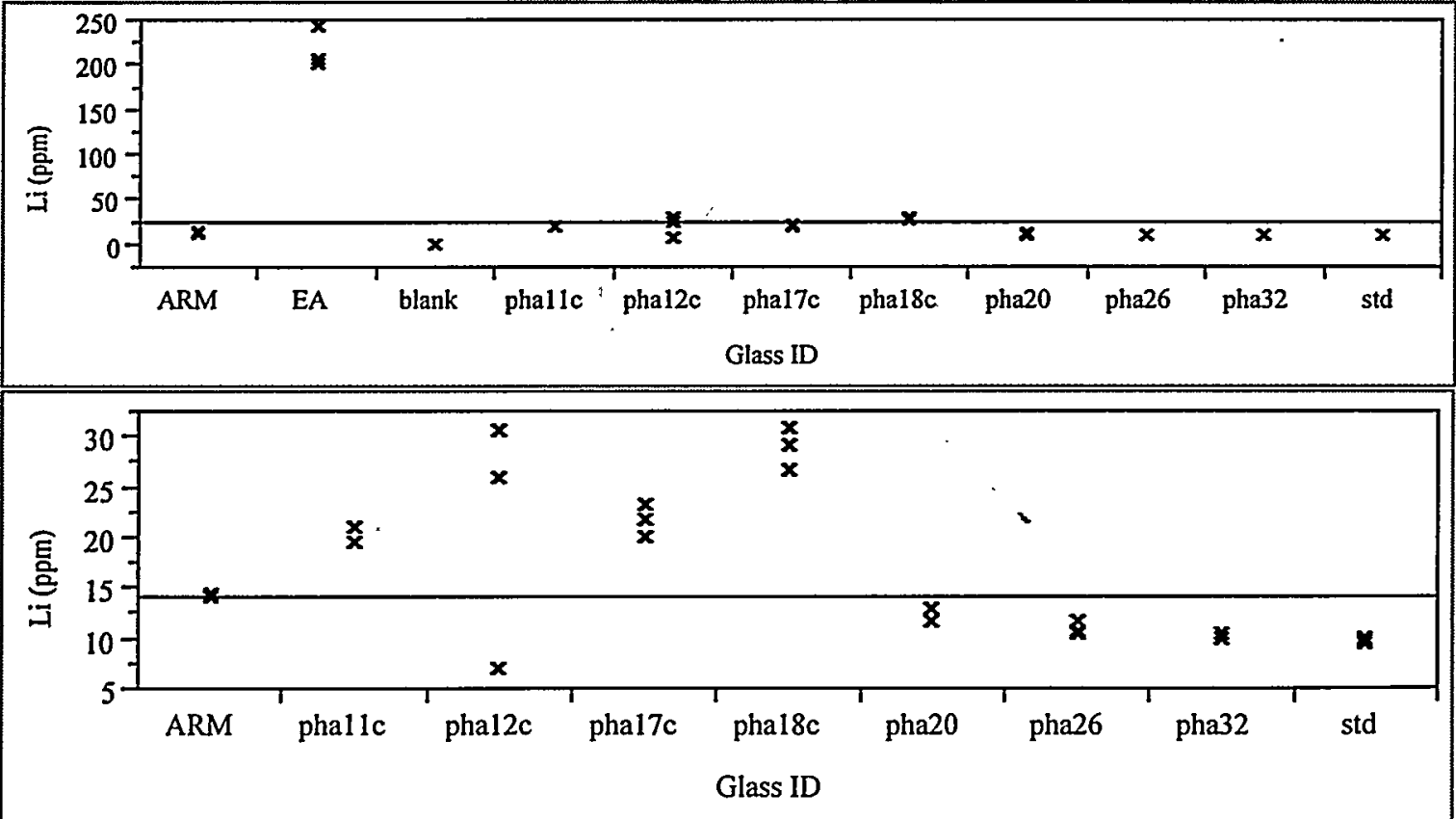
Exhibit A.6: Scatter Plots of the Normalized PCT's

Variable

$\log N \mathrm{~L}[\mathrm{~B} \mathrm{~g} / \mathrm{L}]$

$\log$ NL[Si $g / L]$

$\log \mathrm{NL}[\mathrm{Na} \mathrm{g} / \mathrm{L}]$

$\log \mathrm{NL}[\mathrm{Li} \mathrm{g} / \mathrm{L}]$

Correlations Using Target Compositions

$\begin{array}{rrrr}\log N L[B \mathrm{~g} / \mathrm{L}] & \log \mathrm{NL}[\mathrm{Si} / \mathrm{L}] & \log \mathrm{NL}[\mathrm{Na} \mathrm{g} / \mathrm{L}] & \log \mathrm{NL}[\mathrm{Li} \mathrm{g} / \mathrm{L}] \\ 1.0000 & 0.9902 & 0.9995 & 0.9994 \\ 0.9902 & 1.0000 & 0.9902 & 0.9902 \\ 0.9995 & 0.9902 & 1.0000 & 0.9997 \\ 0.9994 & 0.9902 & 0.9997 & 1.0000\end{array}$

\section{Correlations Using Measured Compositions}

Variable $\log \mathrm{NL}[\mathrm{B} g / \mathrm{L}]$

$\log \mathrm{NL}[\mathrm{Si} g / \mathrm{L}]$

0.9919

1.0000

0.9990

0.9933

$\log N L[S i g / L]$

$\log N L[N a g / L]$

1.0000

0.9933

1.0000

0.9997

0.9904

0.9988

$\log N L[\mathrm{Li} g / \mathrm{L}]$

0.9997

0.9904

0.9988

$\log N L[\mathrm{Li} g / L]$

\section{Correlations Using Bias-Corrected Measured Compositions}

Variable $\log \mathrm{NL}[\mathrm{B} \mathrm{g} / \mathrm{L}]$

1.0000

0.9920

0.9990

$\log N L$

$\log \mathrm{NL}[\mathrm{B} \mathrm{g} / \mathrm{L}]$

$\log N L[S i \mathrm{~g} / \mathrm{L}]$

$\log \mathrm{NL}[\mathrm{Na} g / \mathrm{L}]$

0.9997

0.9920
1.0000
0.9933
0.9904

$\mathrm{Na} g /[\mathrm{L}]$

$\log N \mathrm{~L}[\mathrm{Li} \mathrm{g} / \mathrm{L}]$

$\log N \mathrm{~L}[\mathrm{Li} \mathrm{g} / \mathrm{L}]$

0.9997

0.9990
0.9933

1.0000

0.9988
0.9997

0.9904

0.9988

1.0000

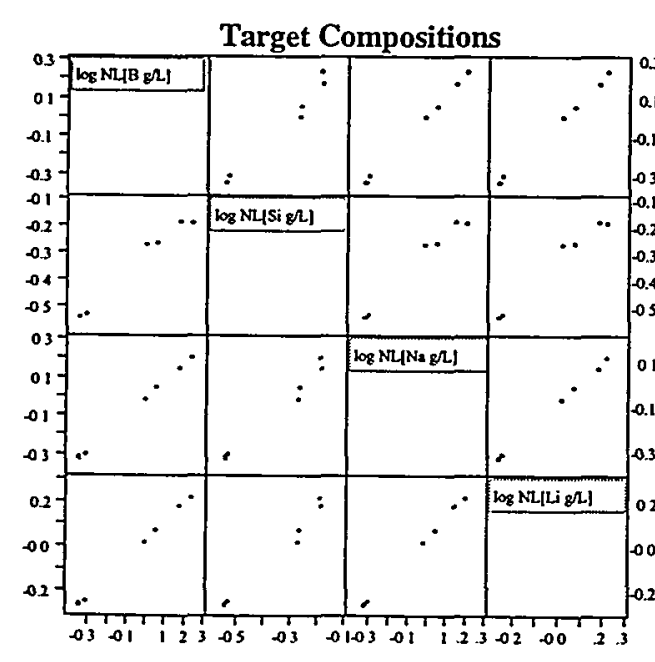

Scatterplot Matrix Measured Compositions Bias-Corrected Measured Compositions
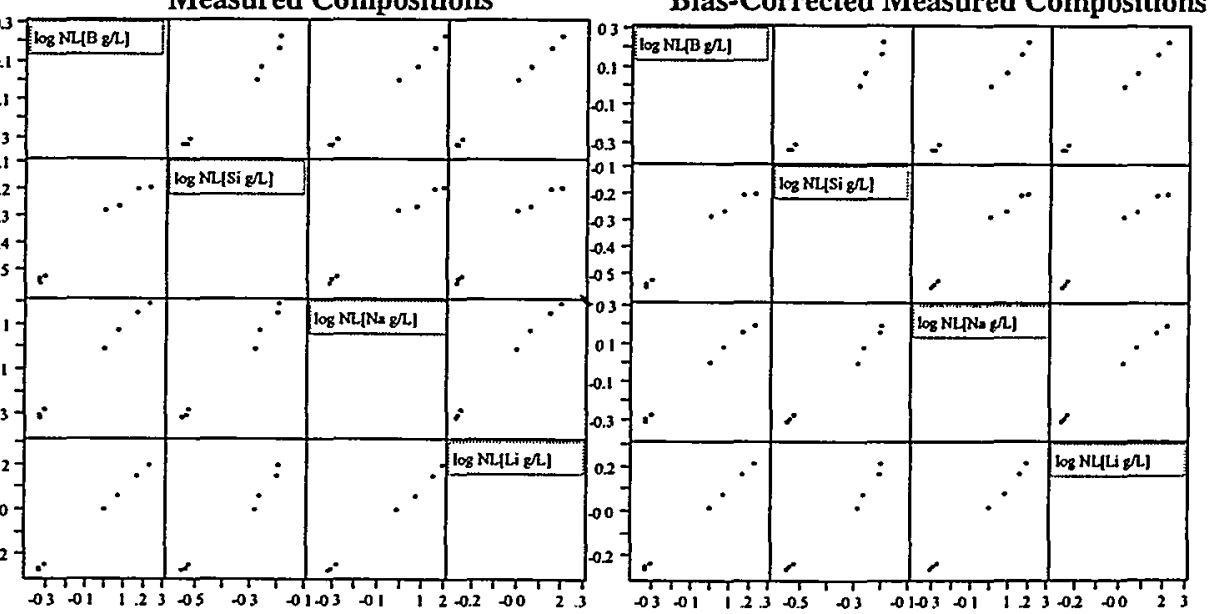


\section{Exhibit A.7: Durability Predictions versus Measured}

(Reference compositions were used to normalize the EA and ARM PCTs; their compositions were not remeasured as part of this study).

$\log \mathrm{NL}(\mathrm{B})(\mathrm{g} / \mathrm{L})$ By del $\mathrm{Gp}(\mathrm{m})$

(based on measured and bias-corrected compositions)

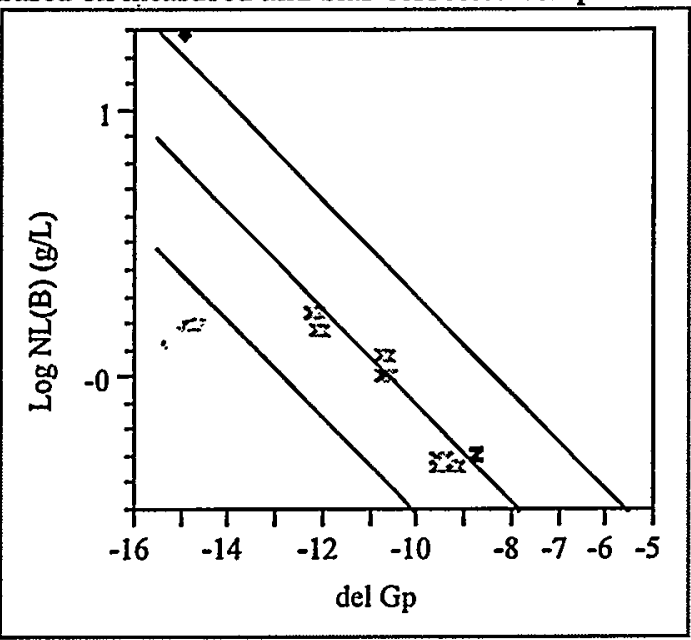

\section{$\log \mathrm{NL}(\mathrm{Si})(\mathrm{g} / \mathrm{L})$ By del $\mathbf{G p}(\mathrm{m})$}

(based on measured and bias-corrected compositions)

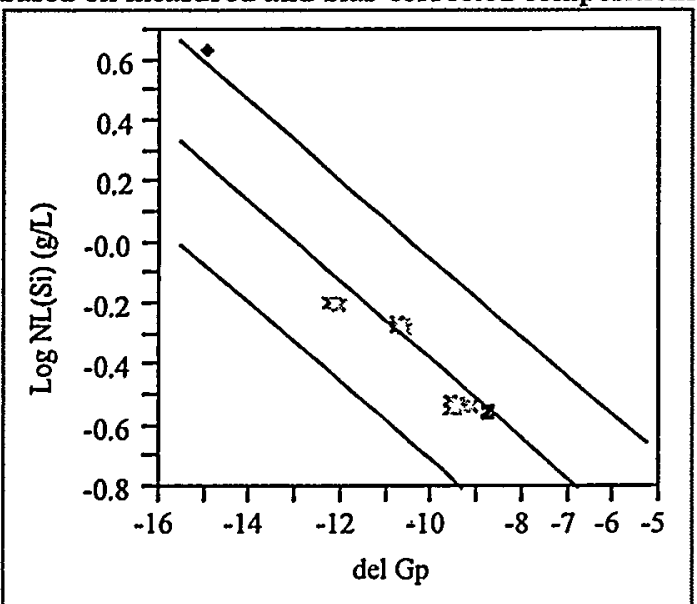

$\log N L(B)(g / L)$ By del Gp(m) (based on target composition)

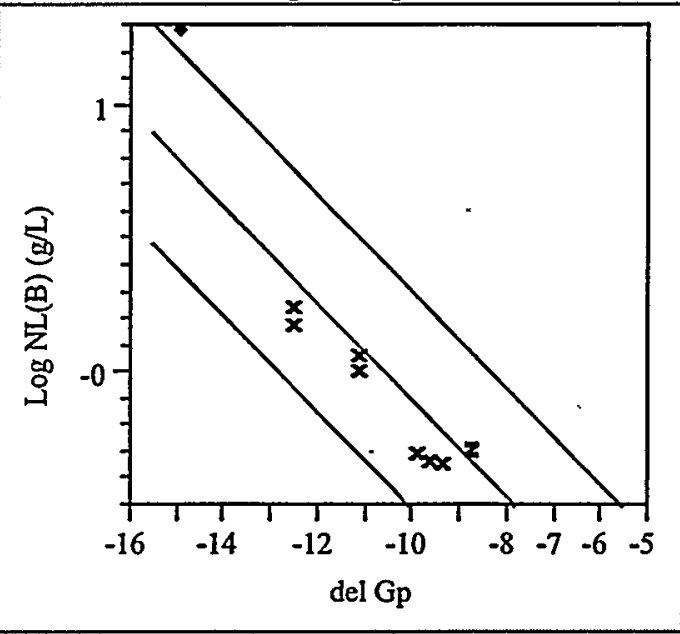

$\log \mathbf{N L}(\mathrm{Si})(\mathrm{g} / \mathrm{L})$ By del Gp(m) (based on target composition)

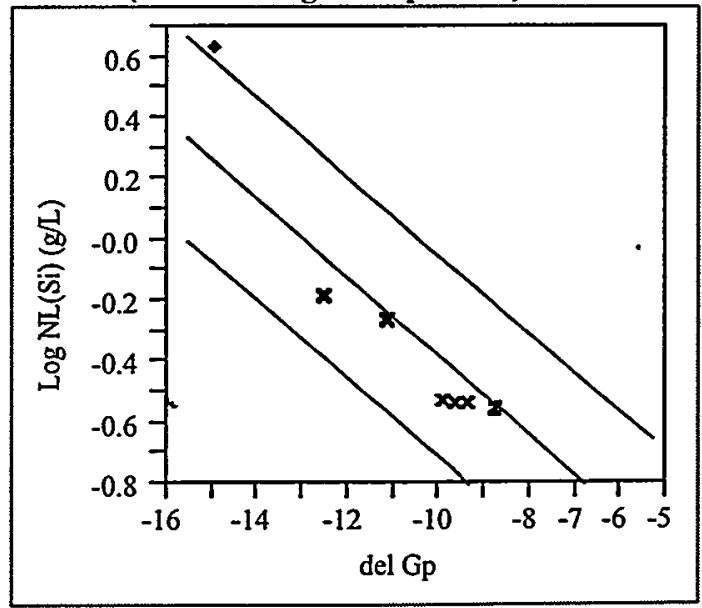




\section{Exhibit A.7: Durability Predictions versus Measured (Continued)}

(Reference compositions were used to normalize the EA and ARM PCTs; their compositions were not remeasured as part of this study).

$\log \mathrm{NL}(\mathrm{Na})(\mathrm{g} / \mathrm{L})$ By del Gp(m)

(based on measured and bias-corrected compositions)

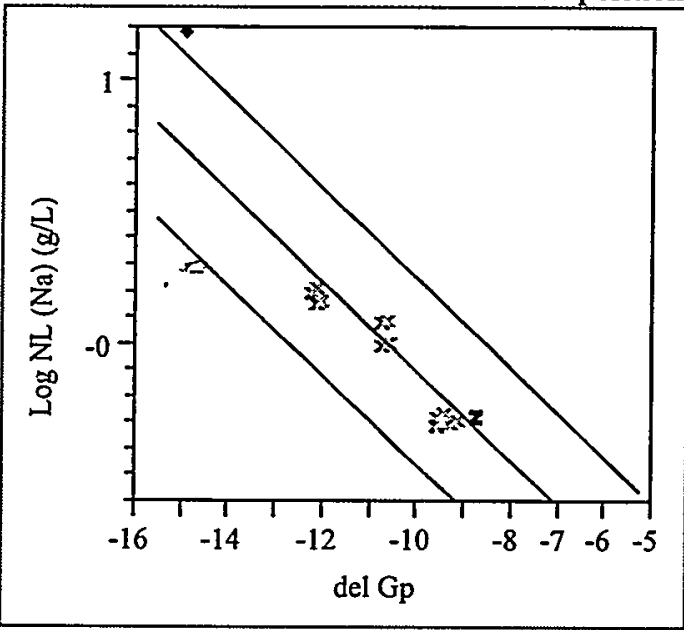

$\log [N L(L i) g / L]$ By del $G p(m)$

(based on measured and bias-corrected compositions)

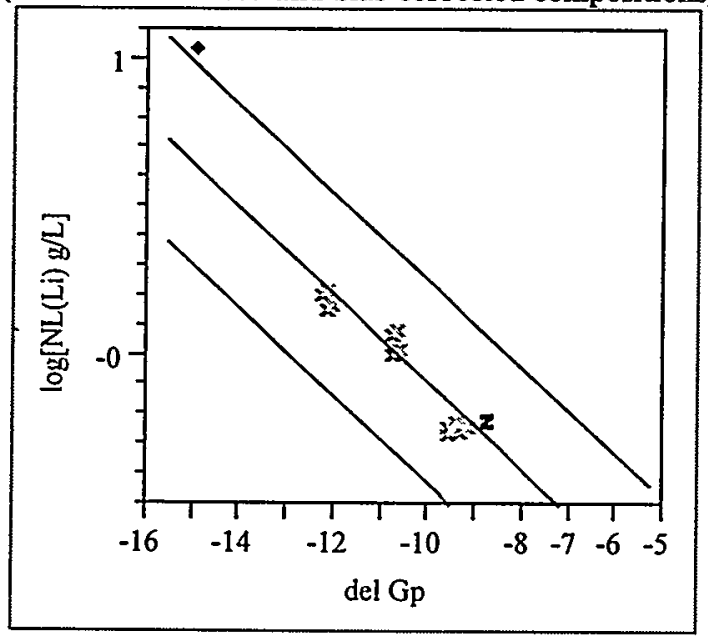

$\log$ NL (Na) (g/L) By del Gp(m) (based on target composition)

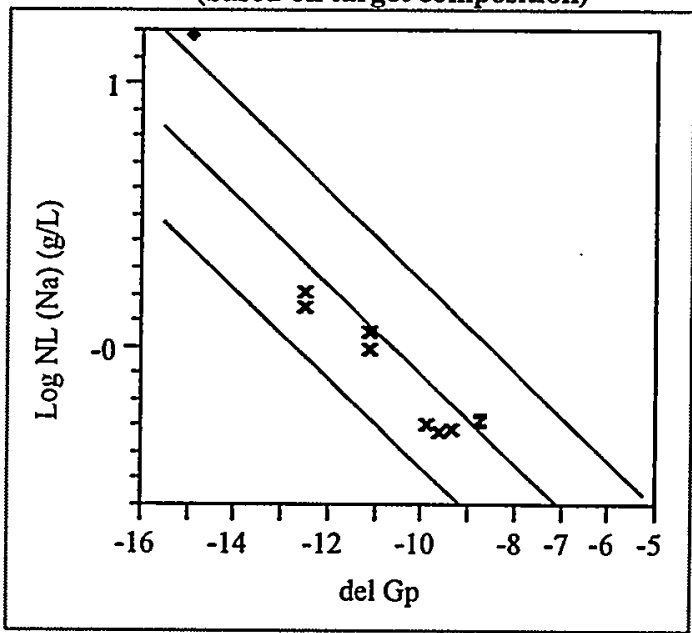

$\log [\mathrm{NL}(\mathrm{Li}) \mathrm{g} / \mathrm{L}]$ By del $\mathrm{Gp}(\mathrm{m})$ (based on target composition)

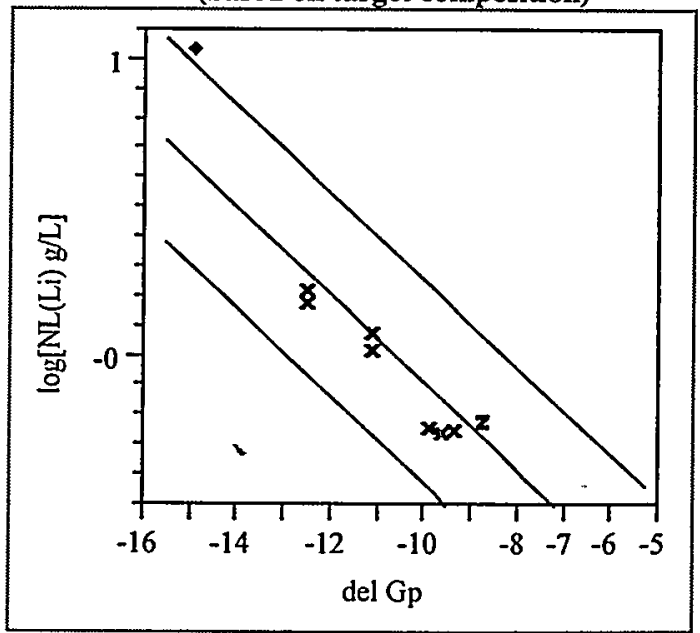


Exhibit A.8: Viscosity Measurements, Fulcher Fits, and Predictions at $1150{ }^{\circ} \mathrm{C}$

\section{pha12c}

$\begin{array}{lrr}\text { Parameter } & \text { Estimate } & \text { ApproxStdErr } \\ \text { A } & -0.063709145 & 1.00620386 \\ \text { B } & 1756.0588712 & 965.5977 .07 \\ \text { C } & 630.87637002 & 130.143989\end{array}$

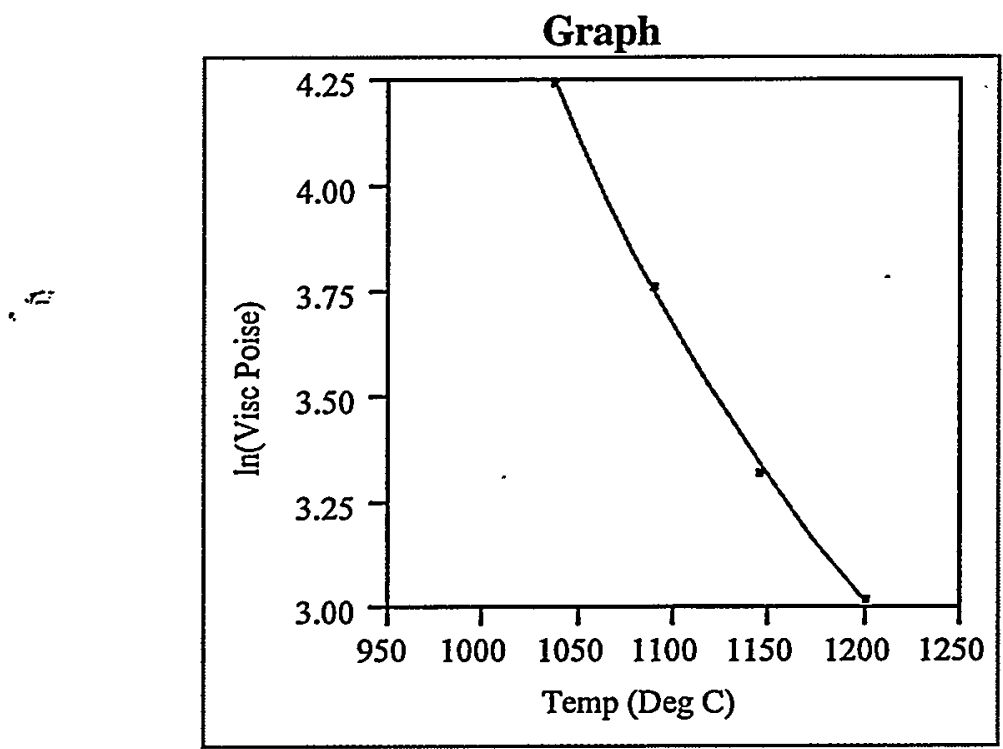

$\begin{array}{lrrrr}\text { Temp (Deg C) } & \text { Visc (Poise) } & \text { In Visc (Fulcher) } & \ln \text { (Visc Poise) } & \text { Visc Pred (Poise) } \\ 1201 & 20.56894 & 3.016428 & 3.023782 & 20.42 \\ 1146 & 27.85945 & 3.345296 & 3.327172 & 28.37 \\ 1091 & 43.27252 & 3.752784 & 3.767518 & 42.64 \\ 1038 & 69.80163 & 4.249622 & 4.245657 & 70.08 \\ 1150 & ? & 3.319028 & ? & 27.63\end{array}$


Exhibit A.8: Viscosity Measurements, Fulcher Fits, and Predictions at $1150{ }^{\circ} \mathrm{C}$ (continued)

\section{pha15c}

$\begin{array}{lrr}\text { Parameter } & \text { Estimate } & \text { ApproxStdErr } \\ \text { A } & -3.897646475 & 0.70143483 \\ \text { B } & 6567.0040005 & 1217.52255 \\ \text { C } & 215.12529994 & 79.9487732\end{array}$

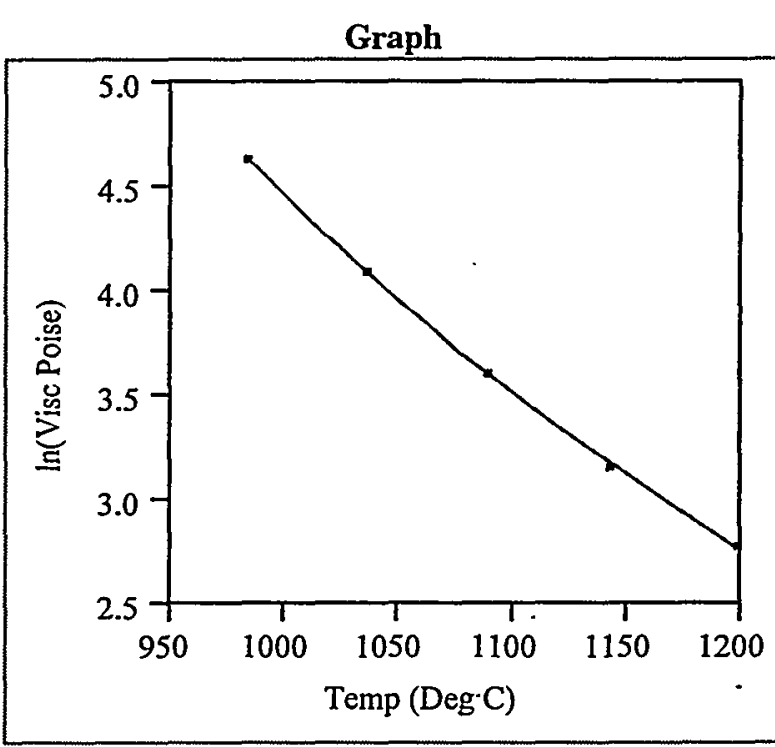

$\begin{array}{lrrrr}\text { Temp (Deg C) } & \text { Visc (Poise) } & \text { ln Visc (Fulcher) } & \ln \text { (Visc Poise) } & \text { Visc Pred (poise) } \\ 1199.5 & 16.10111 & 2.773598 & 2.778888 & 16.02 \\ 1144 & 23.58912 & 3.172203 & 3.160785 & 23.86 \\ 1090.5 & 36.93064 & 3.604288 & 3.609042 & 36.76 \\ 1037 & 60.11118 & 4.092627 & 4.096196 & 59.90 \\ 984 & 103.6705 & 4.643412 & 4.641217 & 103.90 \\ 1150 & ? & 3.126829 & & ?\end{array}$


Exhibit A.8: Viscosity Measurements, Fulcher Fits, and Predictions at $1150{ }^{\circ} \mathrm{C}$ (continued)

\section{pha32}

Parameter Estimate ApproxStdErr =

A $\quad-4.439457996 \quad 1.33524274$

B $\quad 9564.4297263 \quad 2686.15911$

$\begin{array}{lll}\text {. C } & 79.627339442 & 140.57891\end{array}$

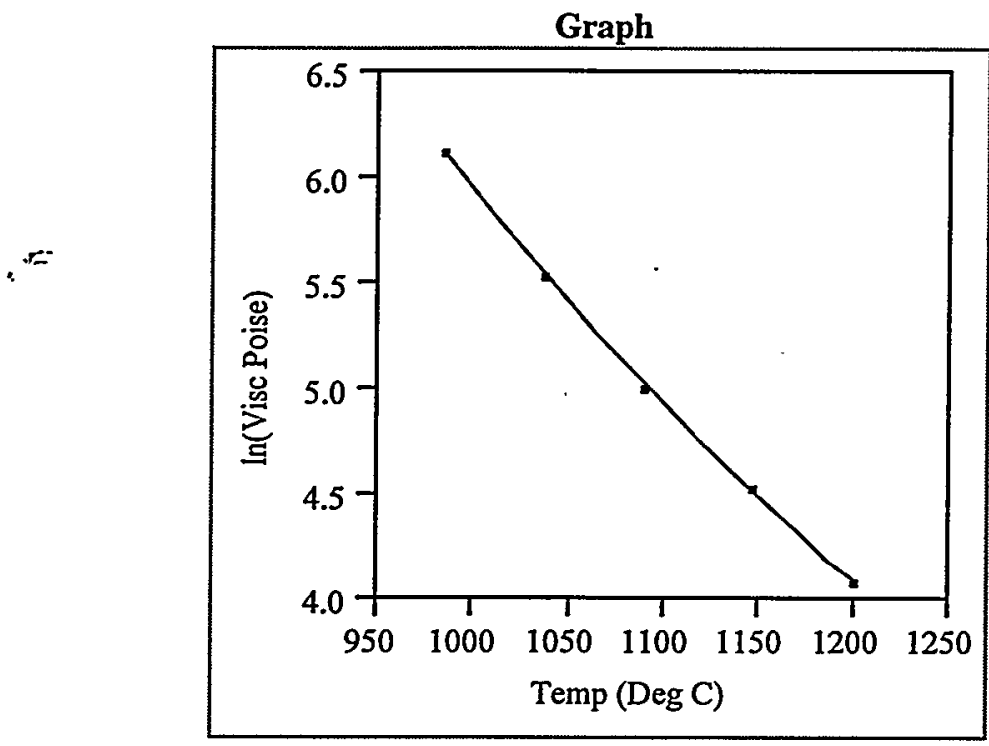

Temp (Deg C)

1200.5

Visc (Poise)

In Visc (Fulcher)

$\ln$ (Visc Poise)

Visc Pred (poise)

59.48209

93.03869

150.2267

1091

1038

253.1414

458.6551

4.093563

4.517068

5.017422

5.540407

6.124623

1150

4.496149

4.085675
4.533015
5.012145
5.533948
6.128299
$?$

59.95

91.57

151.02

254.78

456.97

89.67 
WSRC-TR-99-00294

Revision 0

$=$

This page intentionally left blank. 


\section{Appendix B. Two Additional Glasses: pha14c and pha15c}

This appendix looks at two additional glasses (designated as pha14c and pha15c) that were batched and tested as part of PHA Phase 4. The target compositions for this pair of glasses are available in Table 2. The chemical compositions of these glasses were analyzed by ADS. The results from the analyses are provided in Table B.1 and Table B.2 at the end of this appendix. Plots of these values are provided in Exhibit B.1. No problems are seen in these results and all of the reported values are used in the calculations that follow. With the limited information by the Batch 1 results, no bias correction is conducted for these data. The average compositions for the Batch 1 , pha $14 \mathrm{c}$, and pha $15 \mathrm{c}$ glasses are provided in Chart B.1

Chart B.1: Target and Measured Compositions (in wt\%) for Batch 1, pha14c, and pha15c

\begin{tabular}{|c|c|c|c|c|c|c|}
\hline & & tch 1 & & $a 14 c$ & & $15 c$ \\
\hline & Target & Measured & Target & Measured & Target & Measured \\
\hline $\mathbf{A l}_{2} \mathrm{O}_{3}$ & 4.877 & 4.693 & 3.245 & 3.293 & 3.227 & 3.322 \\
\hline $\mathrm{B}_{2} \mathrm{O}_{3}$ & 7.777 & 7.501 & 8.174 & 7.729 & 9.003 & 8.515 \\
\hline $\mathrm{CaO}$ & 1.220 & 1.364 & 1.234 & 1.393 & 1.230 & 1.351 \\
\hline $\mathrm{Cr}_{2} \mathrm{O}_{3}$ & 0.107 & 0.243 & 0.144 & 0.154 & 0.144 & 0.157 \\
\hline $\mathrm{CuO}$ & 0.399 & 0.417 & 0.808 & 0.813 & 1.031 & 1.022 \\
\hline $\mathrm{Fe}_{2} \mathrm{O}_{3}$ & 12.839 & 13.695 & 13.470 & 13.760 & 13.467 & 13.621 \\
\hline $\mathbf{K}_{2} \mathbf{O}$ & 3,327 & 3.160 & 4.760 & 4.487 & 6.140 & 5.389 \\
\hline $\mathrm{Li}_{2} \mathrm{O}$ & 4.429 & 4.568 & 4.030 & 3.979 & 3.824 & 3.797 \\
\hline MgO & 1.419 & 1.415 & 1.255 & 1.271 & 1.195 & 1.215 \\
\hline MnO & 1.726 & 1.705 & 2.355 & 2.483 & 2.355 & 2.500 \\
\hline $\mathrm{Na}_{2} \mathrm{O}$ & 9.003 & 9.215 & 8.511 & 8.457 & 8.659 & 8.694 \\
\hline NiO & 0.751 & 0.894 & 1.268 & 1.195 & 1.268 & 1.186 \\
\hline $\mathrm{SiO}_{2}$ & 50.220 & 48.336 & 45.569 & 44.149 & 43.289 & 41.745 \\
\hline $\mathrm{TiO}_{2}$ & 0.677 & 0.688 & 1.123 & 1.139 & 1.122 & 1.135 \\
\hline $\mathrm{U}_{3} \mathrm{O}_{8}$ & 0.000 & 0.354 & 2.731 & 2.460 & 2.731 & 2.611 \\
\hline $\mathrm{ZrO}_{2}$ & 0.098 & 0.148 & 0.149 & 0.215 & 0.149 & 0.196 \\
\hline Sum of Oxides & 98.869 & 98.469 & 98.826 & 97.052 & 98.834 & 96.530 \\
\hline
\end{tabular}

These glasses were subjected to the Product Consistency Test (in triplicate) along with the typical standard glasses and solutions. The results were analyzed by ADS and Table B.3 provides the data from these analyses. The results are plotted in Exhibit B.2 (with and without the EA and blank samples), and no problems are seen in these data. The results from measurements of three samples of the standard multi-element solution are provided in this table and exhibit. They are summarized in Chart B.2. No indication of a problem is seen in these results.

Chart B.2: Measurements of Standard Solution

\begin{tabular}{|c|c|c|c|c|c|}
\hline Block & Sequence & B (ppm) & Si (ppm) & Na (ppm) & Li (ppm) \\
\hline 1 & 1 & 19.5 & 48.9 & 82.7 & 9.9 \\
\hline 1 & 1 & 19.8 & 49.5 & 84.2 & 10.1 \\
\hline 1 & 1 & 19.7 & 49.0 & 83.5 & 10.0 \\
\hline Block 1 & average & 19.34 & 49.22 & 81.29 & 9.63 \\
\hline Reference & Value & 20 & 50 & 81 & 10 \\
\hline \multicolumn{2}{|r|}{$\%$ Difference } & $-3.30 \%$ & $-1.55 \%$ & $0.36 \%$ & $-3.73 \%$ \\
\hline
\end{tabular}

The information in Chart B.1 and Table B.3 was used to normalize the PCT results for these glasses. The normalization was conducted as described in the body of the paper. The normalize PCTs are given in Chart B.3.

Chart B.3: Normalized PCTs for Extra Phase Glasses

\begin{tabular}{|cccccccccc|}
\hline \multirow{2}{*}{ Glass ID } & Composition & $\log N L$ & $\log N L$ & $\log N L$ & $\log N L$ & $N L$ & $N L$ & $N L$ & $N L$ \\
ARM & reference comp. [10] & -0.26533 & -0.53190 & -0.25933 & -0.20825 & 0.54 & 0.29 & 0.55 & 0.62 \\
EA & reference comp. [10] & 1.21765 & 0.59582 & 1.12991 & 0.96905 & 16.51 & 3.94 & 13.49 & 9.31 \\
\hline pha14c & measured & 0.06317 & -0.25322 & 0.03246 & 0.03802 & 1.16 & 0.56 & 1.08 & 1.09 \\
& target & 0.03885 & -0.26697 & 0.02967 & 0.03252 & 1.09 & 0.54 & 1.07 & 1.08 \\
\hline pha15c & measured & 0.24023 & -0.19416 & 0.17513 & 0.18018 & 1.74 & 0.64 & 1.50 & 1.51 \\
& target & 0.21601 & -0.20994 & 0.17687 & 0.17711 & 1.64 & 0.62 & 1.50 & 1.50 \\
\hline
\end{tabular}


These PCTs reveal that pha $14 \mathrm{c}$ and pha15c are durable when compared to EA. The DWPF models for durability and their prediction limits (at $95 \%$ confidence) are shown in Figure B.1. The PCT results for EA (shown as a diamond), ARM (shown as a " $z$ "), pha14c, and pha15c. The two glasses, pha14c and pha15c, are each shown as an " $x$ ". The darker " $x$ " represents the results based upon the target compositions for these two glasses and the lighter " $x$ " represents the results based upon the measured compositions. Note that the PCT results for both pha14c and pha15c reveal acceptable PCTs that are well predicted by the current DWPF durability model.

Figure B.1: Durability Predictions versus PCT Measurements

\section{$\log N L(B)(g / L)$ By del Gp}

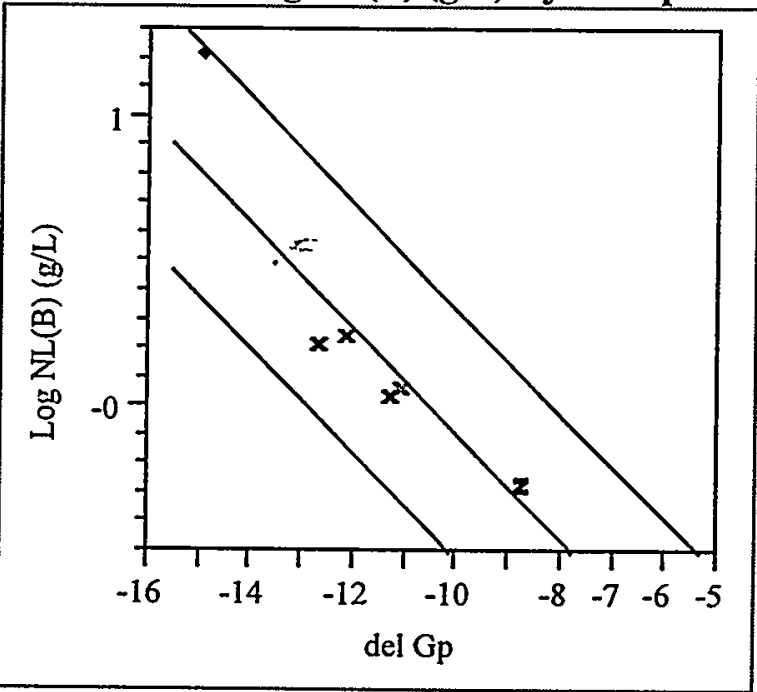

\section{Log NL(Si) (g/L) By del Gp}

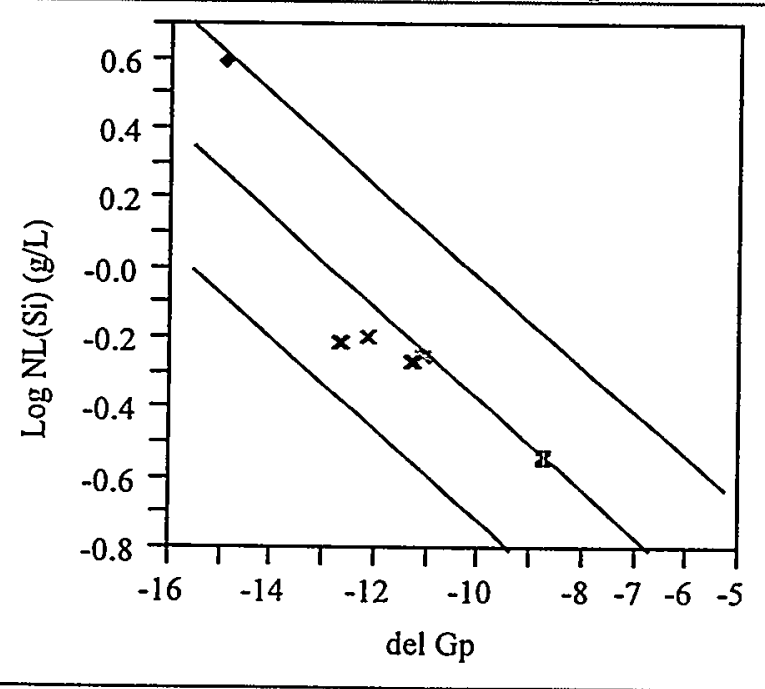

Log NL (Na) (g/L) By del Gp

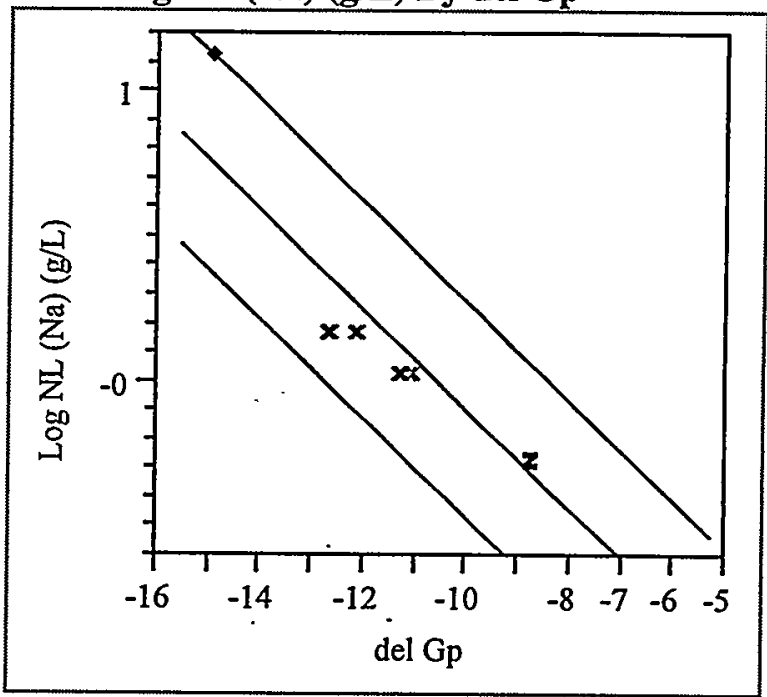

$\log [N L(L i) g / L]$ By del Gp

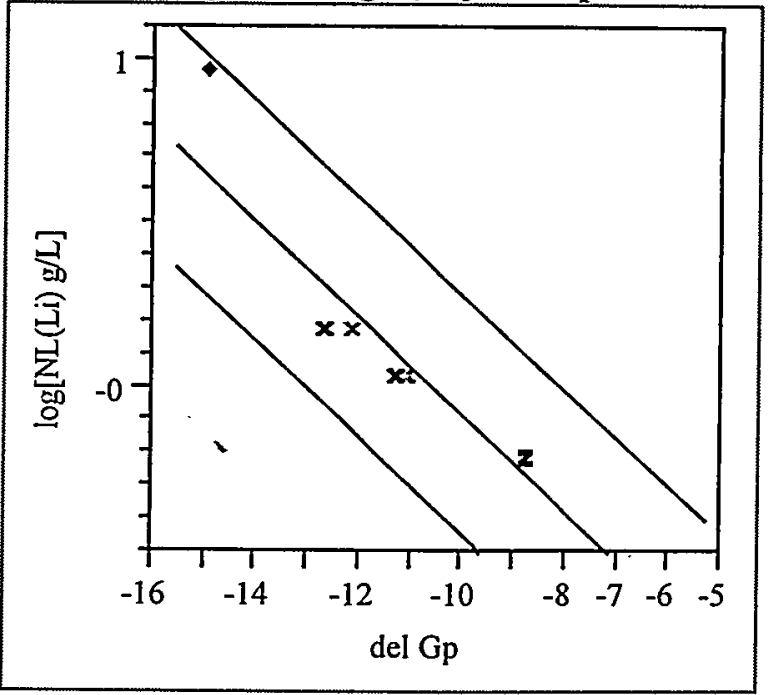


Table B.1: Composition Measurements Using Peroxide Fusion Dissolutions (expressed as cation weight fractions)

\begin{tabular}{|c|c|c|c|c|c|c|c|}
\hline Glass ID & Block & Seg & LIMS \# & Lab ID & B & $\mathrm{Ca}$ & $\mathbf{S i}$ \\
\hline Batch I & 1 & 1 & $13182810 x$ & $\mathrm{Na} 2 \mathrm{O} 2$ - Batch 1 & 0.02345 & 0.00932 & 0.23449 \\
\hline phal $5 \mathrm{c}$ & 1 & 2 & 131827-dup & $\mathrm{Na} 2 \mathrm{O} 2$ - pha $15 \mathrm{C}-2$ & 0.02669 & 0.00902 & 0.19900 \\
\hline phal5c & 1 & 3 & 131826-dup & $\mathrm{Na} 2 \mathrm{O} 2$ - pha $15 \mathrm{C}-1$ & 0.02618 & 0.00981 & 0.19736 \\
\hline pha14c & 1 & 4 & 131825-dup $10 x$ & $\mathrm{Na} 2 \mathrm{O} 2$ - pha $14 \mathrm{C}-2$ & 0.02374 & 0.00978 & 0.20706 \\
\hline phal4c & 1 & 5 & 131824-dup & $\mathrm{Na} 2 \mathrm{O} 2$ - pha $14 \mathrm{C}-1$ & 0.02400 & 0.01019 & 0.20938 \\
\hline phalsc & 1 & $\frac{2}{6}$ & $13182710 \mathrm{x}$ & $\mathrm{Na} 2 \mathrm{O} 2$ - pha $15 \mathrm{C}-2$ & 0.02680 & 0.00908 & 0.19993 \\
\hline phal5c & 1 & 7 & $13182610 x$ & $\mathrm{Na2O} 2$ - pha 15C-1 & 0.02610 & 0.00977 & 0.19751 \\
\hline phal $4 c$ & 1 & 8 & $13182510 x$ & $\mathrm{Na} 2 \mathrm{O} 2$ - pha $14 \mathrm{C}-2$ & 0.02415 & 0.00997 & 0.21106 \\
\hline pha14c & 1 & 9 & $13182410 x$ & $\mathrm{Na} 2 \mathrm{O} 2$ - pha $14 \mathrm{C}-1$ & 0.02412 & 0.01032 & 0.21060 \\
\hline Batch 1 & 1 & 10 & 131828-dup & $\mathrm{Na} 2 \mathrm{O} 2-\mathrm{Batch} 1$ & 0.02314 & 0.00927 & 0.23055 \\
\hline
\end{tabular}

Values at their detection limits were set to their detection limits.

$=$ 
WSRC-TR-99-00294

Revision 0

Table B.2: Composition Measurements From Microwave Preparation (expressed as cation weight fractions)

\begin{tabular}{|c|c|c|c|c|c|c|c|c|c|c|c|c|c|c|c|c|c|c|c|c|}
\hline Glass & & & & & & & & & & & & ICP-ES & & & & & & & & $\mathrm{AA}^{6}$ \\
\hline ID & Block & Seq & LIMS \# & Lab ID & Al & $\mathrm{Ca}$ & $\mathrm{Cr}$ & $\mathbf{C u}$ & $F_{c}$ & $\mathrm{~L}$ & $\mathbf{M g}$ & $\mathrm{Mn}$ & $\mathrm{Na}$ & $\mathrm{Nb}$ & $\mathrm{NI}$ & S! & Ti & $\mathbf{U}$ & $\mathbf{Z r}$ & $\mathbf{K}$ \\
\hline Batch ! & 1 & 1 & 131739 & MW10x - Batch 1 & 0.02538 & 0.01030 & 0.00176 & 0.00338 & 0.09840 & 0.02098 & 0.00882 & 0.01367 & 0.06815 & 0.00051 & 0.00733 & 0.22431 & 0.00424 & 0.00301 & 0.00137 & 0.02683 \\
\hline phalsc & $\mathrm{T}$ & 2 & 131738-dup & MW10x - pha $15 \mathrm{C}-2$ & 0.01783 & 0.01011 & 0.00103 & 0.00826 & 0.09520 & 0.01818 & \begin{tabular}{|l|l|}
0.00735 \\
\end{tabular} & 0.01922 & 0.0666 & 0.00050 & 0.00920 & 0.19250 & 0.00681 & 0.02203 & 0.00138 & 0.04358 \\
\hline pha15c & $T$ & 3 & 131737-dup & MW10x - pha 15C-1 & 0.01733 & 0.00979 & 0.00106 & 0.00817 & 0.09460 & 0.01776 & 0.00718 & 0.01917 & 0.06401 & 0.00050 & \begin{tabular}{|l|}
0.00926 \\
\end{tabular} & 0.18951 & 0.00676 & 0.02232 & 0.00140 & 0.04317 \\
\hline phal $4 c$ & 1 & 4 & 131734-dup & MW10x - pha $14 \mathrm{C}-2$ & 0.01740 & 0.00982 & 0.00104 & 0.00648 & 0.09542 & 0.01860 & 0.00762 & 0.01901 & 0.06332 & 0.00052 & 0.00925 & 0.20166 & 0.00678 & 0.02084 & 0.00145 & 0.03556 \\
\hline phal $4 \mathrm{c}$ & $!$ & 5 & 131732-dup & $=$ pha 14C-1 & 0.01731 & 0.00984 & 0.00103 & 0.00650 & 0.09602 & 0.01849 & 0.00762 & 0.01916 & 0.06233 & 0.00054 & 0.00936 & 0.20303 & 0.00682 & 0.02022 & 10150 & 0.03483 \\
\hline phalsc & 1 & 6 & 131738 & MW10x - pha $15 \mathrm{C}-2$ & 0.01777 & 0.00991 & 0.00110 & 0.00814 & 0.09575 & 0.01739 & 0.00748 & 0.01953 & 0.06476 & 0.00050 & 0.00940 & \begin{tabular}{|l|}
0.19401 \\
\end{tabular} & 0.00682 & \begin{tabular}{|l|}
0.02213 \\
\end{tabular} & 0.00149 & 0.04635 \\
\hline phal5c & $\frac{1}{1}$ & 7 & 131737 & MW10x - pha $15 \mathrm{C}-1$ & 0.01741 & 0.00974 & 0.00110 & 0.00809 & 0.09555 & 0.01722 & 0.00731 & 0.01953 & 0.06259 & 0.00050 & 0.00944 & 0.19123 & 0.00682 & 0.02209 & 154 & 0.04587 \\
\hline phal4c & 1 & 8 & 131734 & MW10x - pha 14C-2 & 0.01750 & 0.00985 & 0.00108 & 0.00648 & 0.09667 & 0.01836 & 0.00774 & 0.01937 & 0.06298 & 0.00052 & 0.00949 & 0.20309 & 0.00685 & 0.02138 & 0.00163 & 0.03818 \\
\hline phal $4 c$ & 1 & 2 & 131732 & MW10x - pha 14C-1 & 0.01751 & 0.00987 & 0.00107 & 0.00651 & 0.09687 & 0.01849 & 0.00767 & 0.01938 & 0.06230 & 0.00054 & 0.00946 & 0.20510 & 0.00687 & 0.02099 & 0.00178 & 0.04044 \\
\hline Barch 1 & 1 & 10 & 131739 -dup & MWI0x - Batch 1 & 0.02429 & 0.01010 & 0.00156 & 0.00328 & 0.09317 & 0.02146 & 0.00824 & 0.01274 & 0.06857 & 0.00051 & 0.00673 & 0.21442 & 0.00401 & \begin{tabular}{|l|}
0.00301 \\
\end{tabular} & 0.00081 & 0.02564 \\
\hline
\end{tabular}

Values at their detection limits were set to their detection limits.

6 The potassium values were generated via Atomic Absorption (AA). 
WSRC-TR-99-00294

Revision 0

Table B.3: Composition of PCT Leachate Solutions for Batch 1, ARM, pha14c, and pha15c

\begin{tabular}{|c|c|c|c|c|c|c|c|c|c|c|c|c|c|c|c|c|c|c|}
\hline \multirow{3}{*}{$\frac{\text { Glass }}{\text { ID }}$} & \multirow[b]{3}{*}{ Blk } & \multirow[b]{3}{*}{ Seq } & \multirow[b]{3}{*}{ LIMS \# } & \multirow{3}{*}{\begin{tabular}{|l|} 
\\
\end{tabular}} & & & \\
\hline & & & & & & & & & & & & & & & \multicolumn{4}{|c|}{ Common Logarithm of ppm Concentrations } \\
\hline & & & & & \multicolumn{5}{|c|}{$\begin{array}{l}\text { (as reported) } \\
\end{array}$} & \multicolumn{5}{|c|}{ 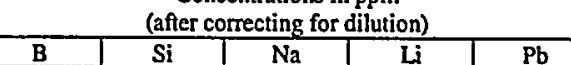 } & $\log [\mathrm{B}]$ & $\log [S i]$ & $\log [\mathrm{Na}]$ & $\log [\mathrm{Li}]$ \\
\hline std & 1 & 1 & 132114 & PCT leachate - Std-1 & 19.45 & 9.66 & 81.52 & 0.03 & 49.44 & 19.45 & 49.44 & 81.52 & 9.66 & 0.03 & 1.28885 & 1.69409 & 1.91125 & 0.98511 \\
\hline EA & 1 & 2 & 132129 & PCT leachate - EA-3 & 361.98 & 115.01 & 1049.48 & 0.29 & 555.43 & 603.31 & 925.73 & 1749.17 & $191: 69$ & 0.48 & 2.78054 & 2.96648 & 3.24283 & $\frac{0.30012}{2.28259}$ \\
\hline EA & 1 & 3 & 132128 & PCT leachate-EA-2 & 370.15 & 117.56 & 1061.62 & 0.29 & 560.26 & 616.93 & 933.78 & 1769.40 & 195.94 & 0.48 & 2.79024 & 2.97024 & 3.24783 & 2.29212 \\
\hline EA & 1 & 4 & 132127 & PCT leachate - EA-I & 313.35 & 99.94 & 920.58 & 0.29 & 502.87 & 522.26 & 838.14 & 1534.33 & 166.57 & 0.48 & 2.71788 & 2.92332 & 3.18592 & $\frac{2.27216}{2.22160}$ \\
\hline pha15c & 1 & 5 & 132126 & PCT leach-Pha 15C-3 & 27.46 & 15.96 & 57.56 & 0.03 & 75.75 & 45.77 & 126.26 & 95.94 & 26.59 & 0.05 & 1.66061 & 2.10125 & $\frac{0.20376}{1.98199}$ & $\frac{2.22100}{1.42478}$ \\
\hline pha15c & 1 & 6 & 132125 & PCT leach- Pha $15 \mathrm{C}-2$ & 27.72 & 16.15 & 58.37 & 0.03 & 74.58 & 46.21 & 124.30 & 97.29 & 26.92 & 0.05 & 1.66471 & 2.09446 & 1.98808 & 1.43003 \\
\hline phal5c & 1 & 7 & 132124 & PCT leach-Pha $15 \mathrm{C}-1$ & 27.57 & 15.96 & 57.81 & 0.03 & 74.29 & 45.96 & 123.82 & 96.35 & 26.61 & 0.05 & 1.66236 & 2.09279 & 1.98387 & $\frac{1.42500}{1.4250}$ \\
\hline std & 1 & 8 & 132123 & PCT leachate - Std-2 & 19.31 & 9.59 & 81.09 & 0.03 & 49.35 & 19.31 & 49.35 & 81.09 & 9.59 & 0.03 & 1.28585 & 1.69327 & 1.90895 & 0.98195 \\
\hline phal $4 \mathrm{c}$ & 1 & 9 & 132122 & PCT leach-Pha 14C-3 & 17.08 & 12.34 & 41.58 & 0.03 & 70.53 & 28.47 & 117.55 & 69.29 & 20.57 & 0.05 & 1.45445 & 2.07021 & 1.84070 & $\frac{0.301301}{1.31321}$ \\
\hline pha14c & 1 & 10 & 132121 & PCT leach- Pha 14C-2 & 16.32 & 11.93 & 39.63 & 0.03 & 67.80 & 27.20 & 113.00 & 66.05 & 19.88 & 0.05 & 1.43458 & 2.05307 & 1.81986 & 1.29850 \\
\hline phal4c & 1 & 11 & 132120 & PCT leach- Pha 14C-1 & 16.58 & 12.05 & 40.50 & 0.03 & 69.05 & 27.63 & 115.08 & 67.50 & 20.08 & 0.05 & 1.44131 & 2.06101 & 1.82932 & 1.30270 \\
\hline ARM & 1 & 12 & 132119 & PCT leachate - ARM-3 & 10.90 & 8.54 & 23.03 & 0.03 & 37.82 & 18.16 & 63.03 & 38.39 & 14.24 & 0.05 & 1.25920 & 1.79957 & 1.58417 & 1.15347 \\
\hline ARM & 1 & 13 & 132118 & PCT leachate - ARM-2 & 10.55 & 8.40 & 22.46 & 0.03 & 37.04 & 17.58 & 61.73 & 37.43 & 13.99 & 0.05 & 1.24503 & 1.79052 & 1.57317 & 1.14593 \\
\hline ARM & 1 & 14 & 132117 & PCT leachate - ARM-1 & 12.99 & 9.39 & 25.71 & 0.03 & 40.17 & 21.65 & 66.95 & 42.84 & 15.65 & 0.05 & 1.33550 & 1.82576 & 1.63189 & 1.19438 \\
\hline blank & 1 & 15 & 132116 & PCT leachate - Blk-2 & 0.04 & 0.00 & 0.12 & 0.03 & 0.06 & 0.07 & 0.10 & 0.20 & 0.01 & 0.05 & -1.17608 & -1.00729 & -0.69536 & -2.30102 \\
\hline blank & 1 & 16 & 132115 & PCT leachate - Blk-1 & 0.04 & 0.00 & 0.12 & 0.03 & 0.07 & 0.07 & 0.11 & 0.20 & 0.01 & 0.05 & -1.17608 & -0.96523 & -0.70626 & -2.30102 \\
\hline std & 1 & 17 & 132130 & PCT leachate - Std-3 & 19.26 & 9.63 & 81.26 & 0.03 & 48.88 & 19.26 & 48.88 & 81.26 & 9.63 & 0.03 & 1.28470 & 1.68916 & 1.90989 & 0.98345 \\
\hline
\end{tabular}

Notes:

(1). Values that are below detection (indicated by a " $<$ ") were converted to their detection limit. 
Exhibit B.1: Measurements by Glass Sample ID by Oxide for pha14c and pha15c

$\mathrm{Al} 2 \mathrm{O3}$ (wt\%) By Glass ID

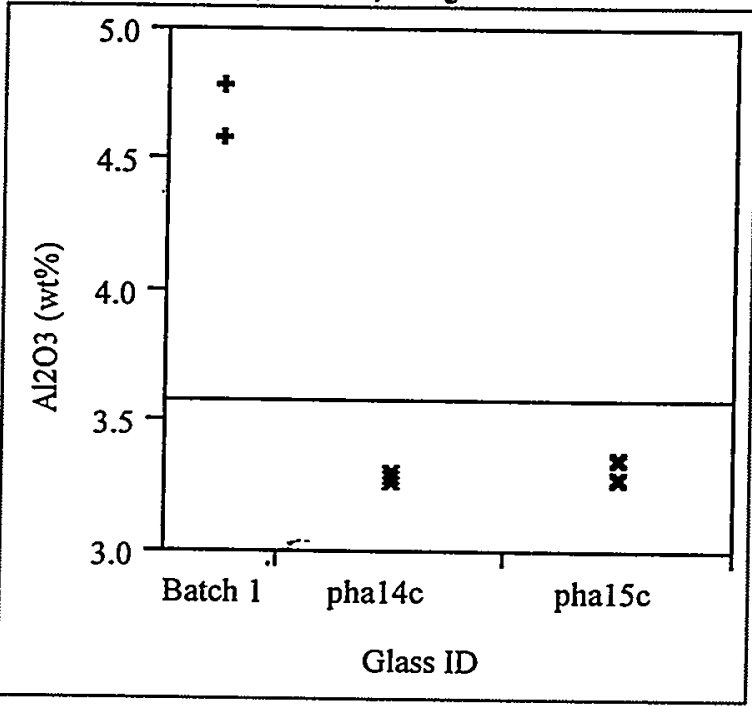

B2O3 (wt\%) By Glass ID

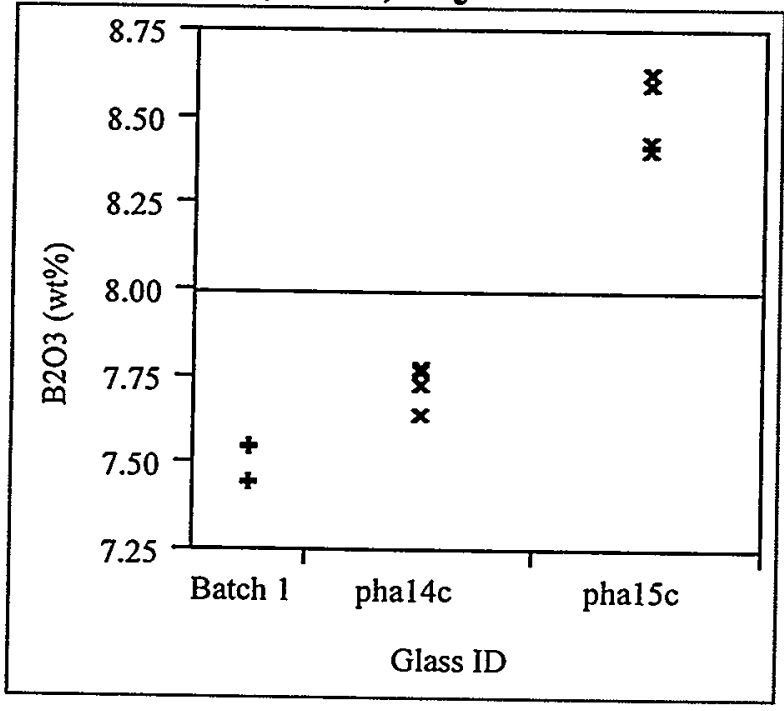

CaO MW (wt\%) By Glass ID

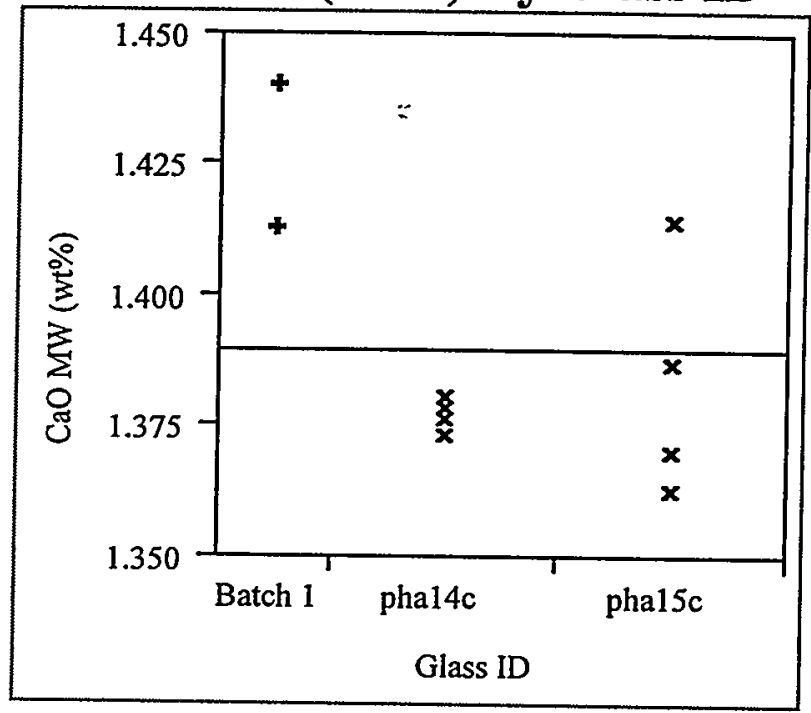

Ca pf (wt\%) By Glass ID

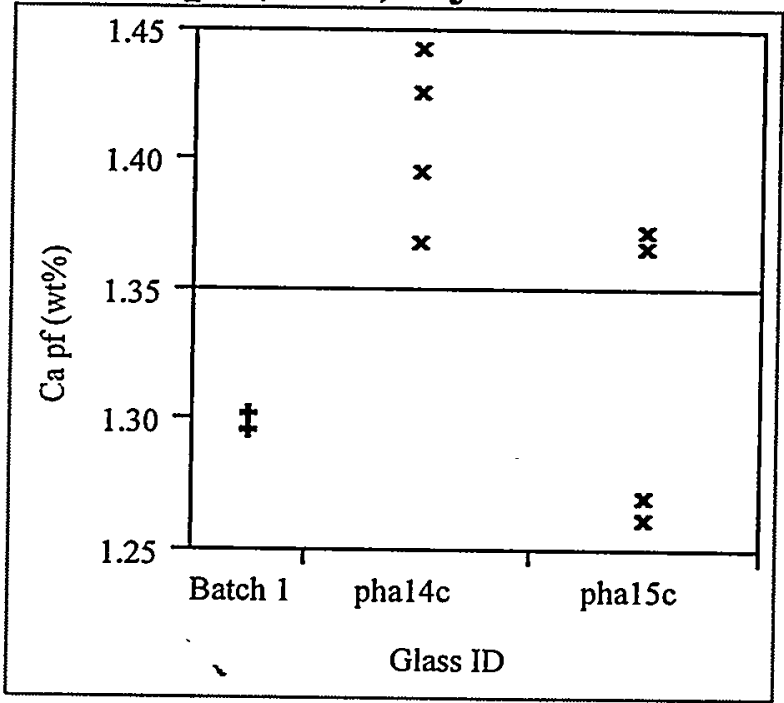


Exhibit B.1: Measurements by Glass Sample ID by Oxide for pha14c and pha15c

$\mathrm{CaO}(\mathrm{wt} \%)$ By Glass ID

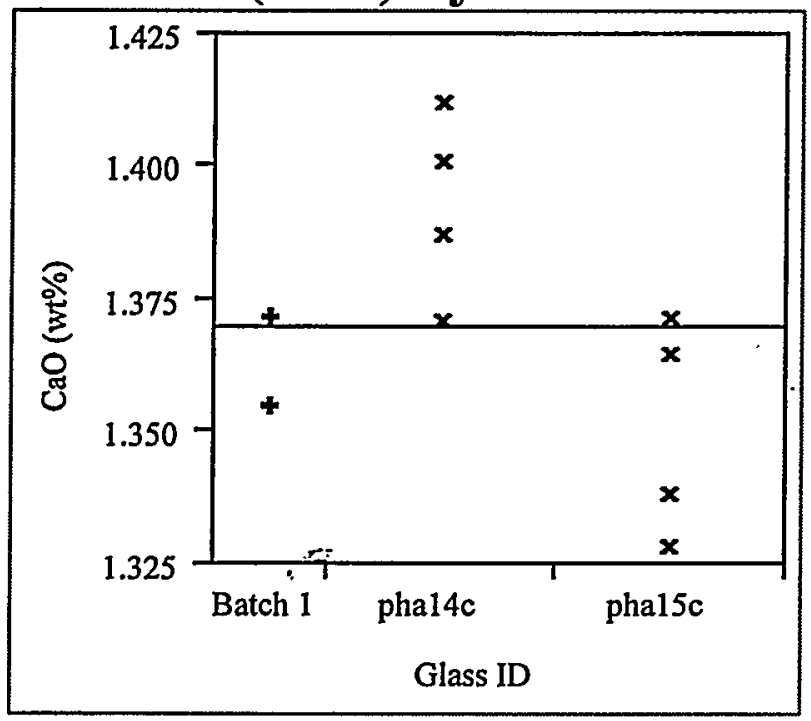

Cr2O3 (wt\%) By Glass ID

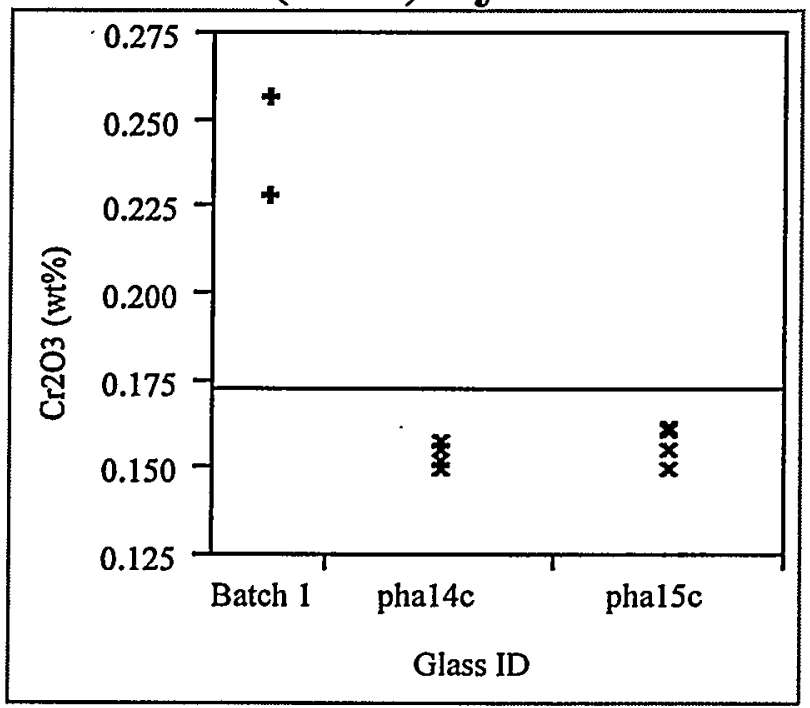

$\mathrm{CuO}$ (wt\%) By Glass ID

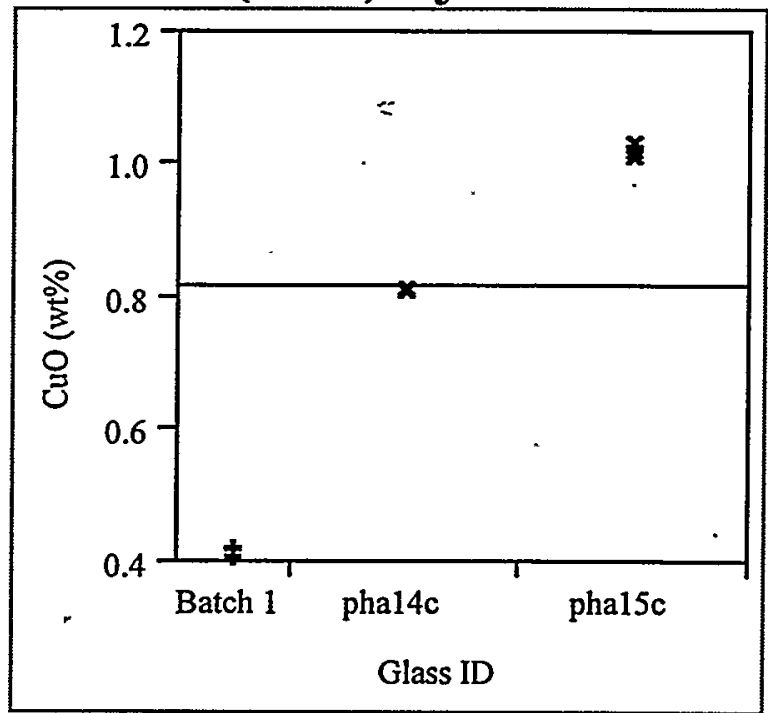

Fe2O3 (wt\%) By Glass ID

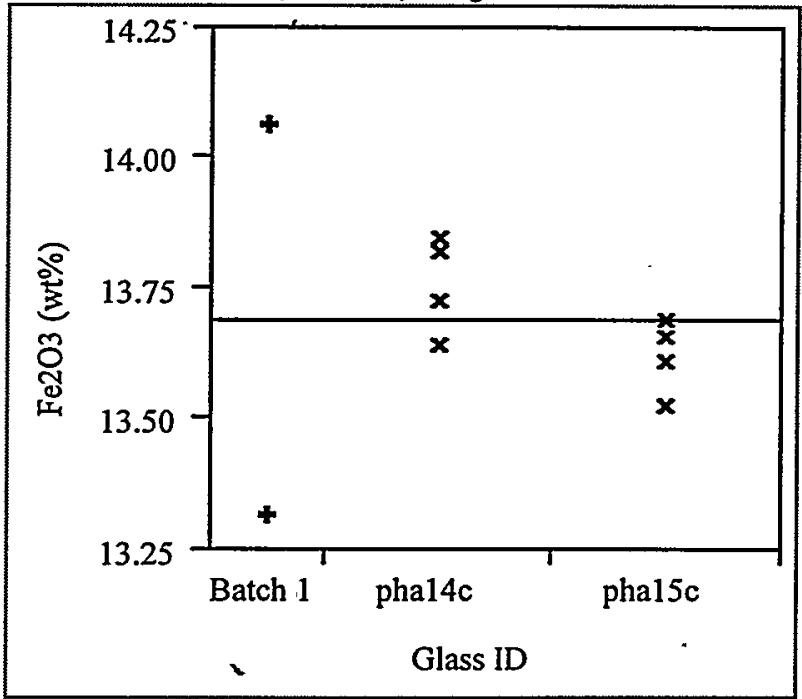


WSRC-TR-99-00294

Revision 0

Exhibit B.1: Measurements by Glass Sample ID by Oxide for pha14c and pha15c

K2O (wt\%) By Glass ID

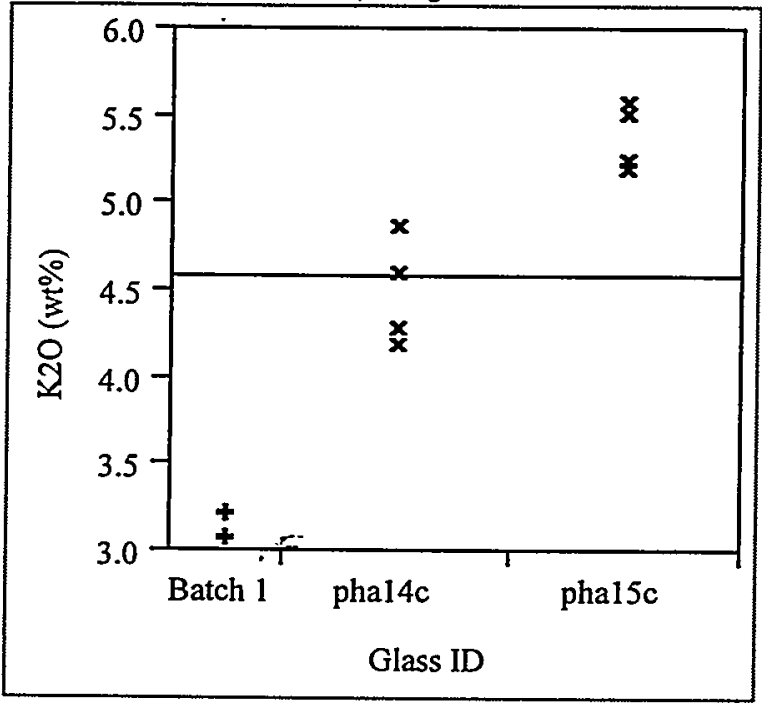

Li2O (wt\%) By Glass ID

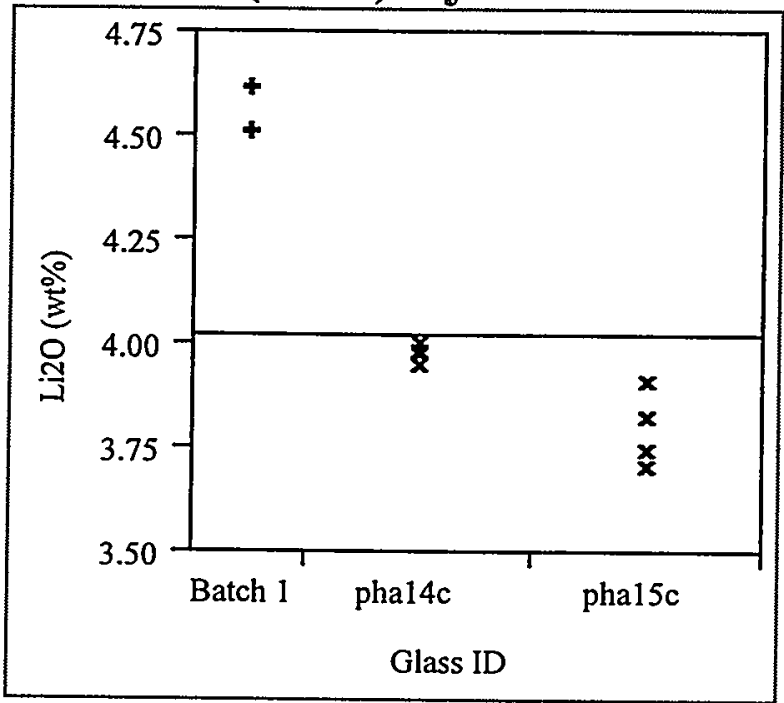

MgO (wt\%) By Glass ID

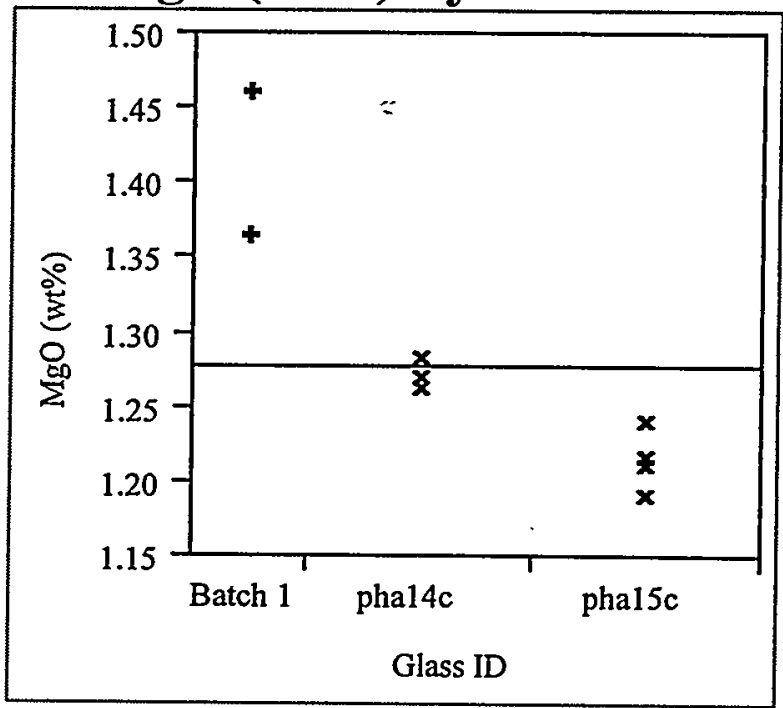

MnO (wt\%) By Glass ID

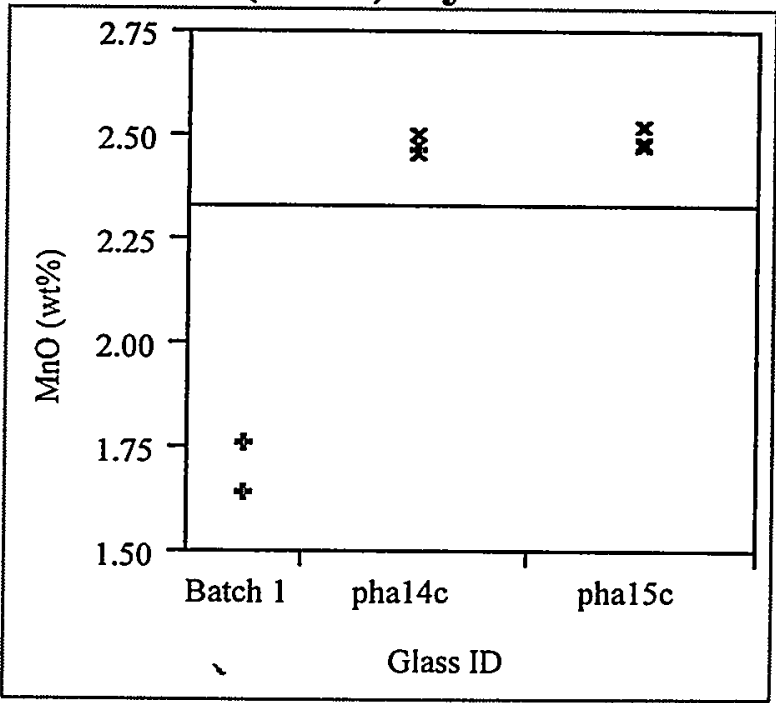


WSRC-TR-99-00294

Revision 0

Exhibit B.1: Measurements by Glass Sample $\mathrm{W}$ by Oxide for pha14c and pha15c

$\mathrm{Na} 20$ (wt\%) By Glass ID

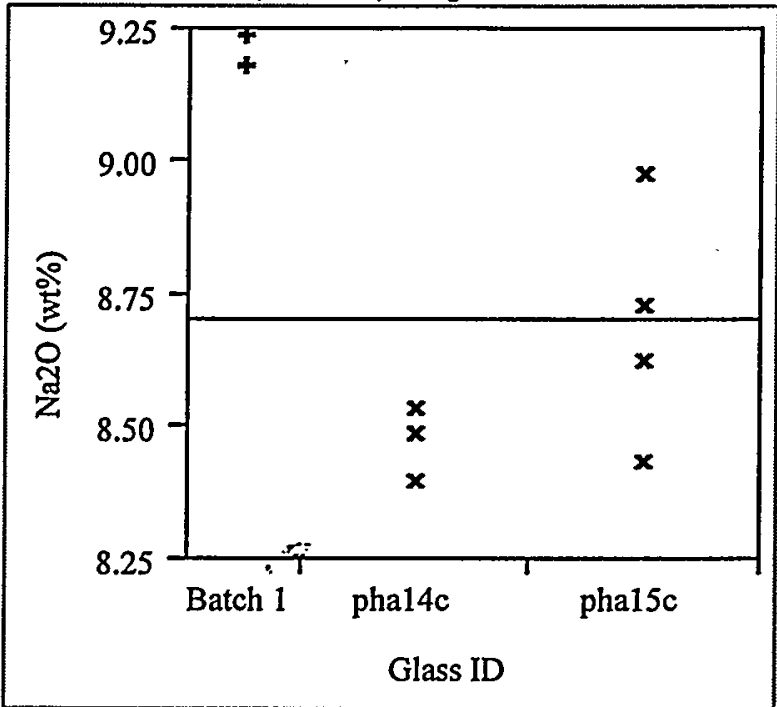

$\mathrm{Nb2O5}(\mathrm{wt} \%)$ By Glass ID

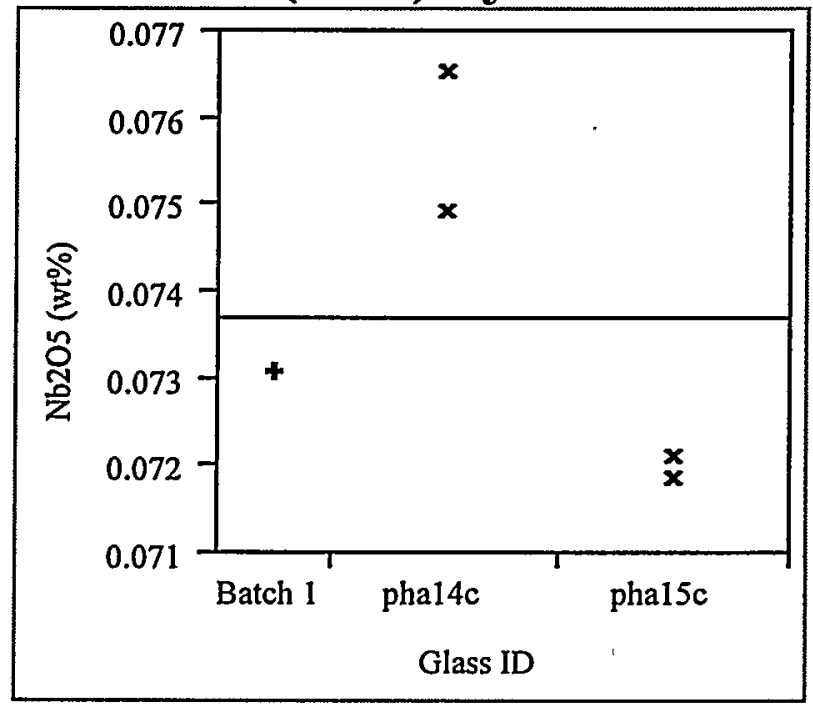

$\mathrm{NiO}(\mathrm{wt} \%$ ) By Glass ID

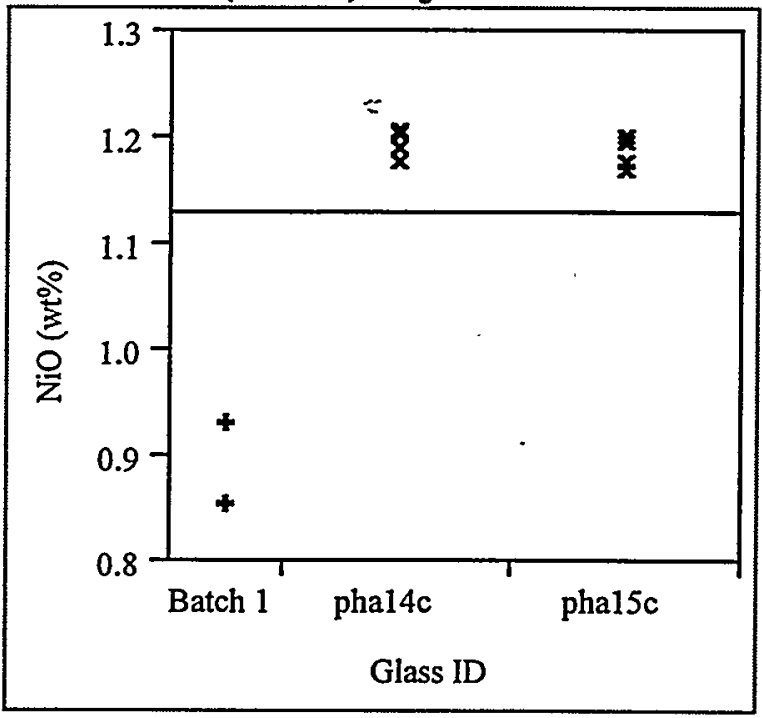

SiO2 MW (wt\%) By Glass ID

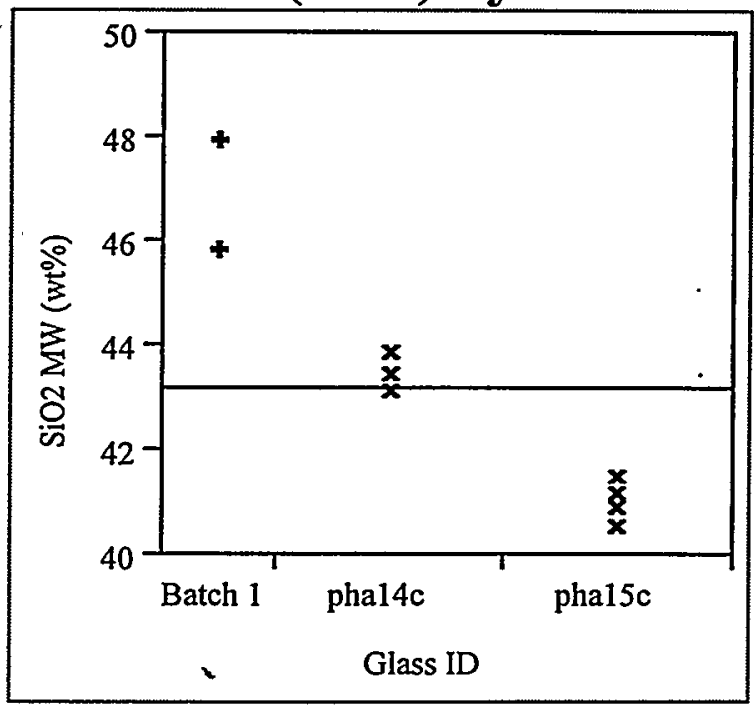


WSRC-TR-99-00294

Revision 0

Exhibit B.1: Measurements by Glass Sample ID by Oxide for pha14c and pha15c

SiO2 pf (wt\%) By Glass ID

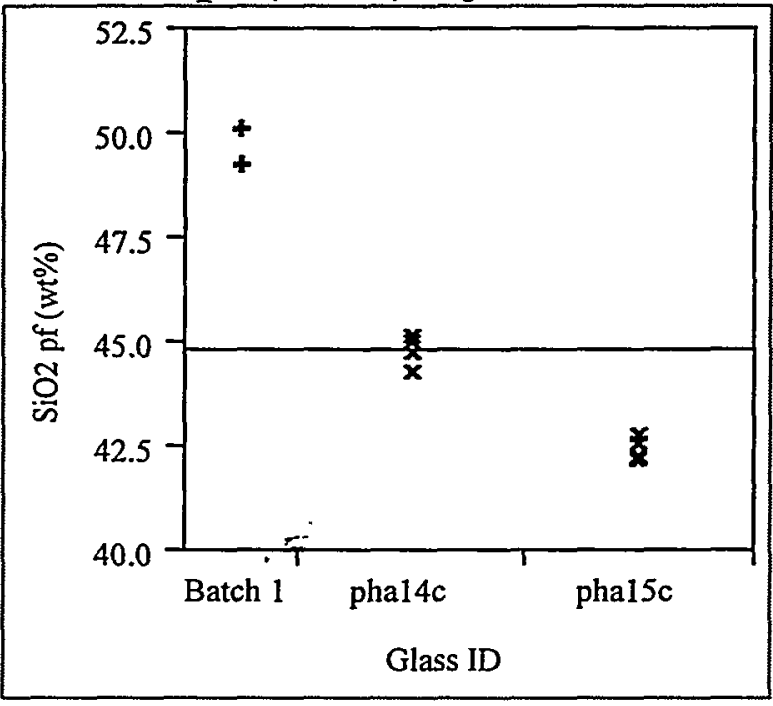

SiO2 (wt\%) By Glass ID

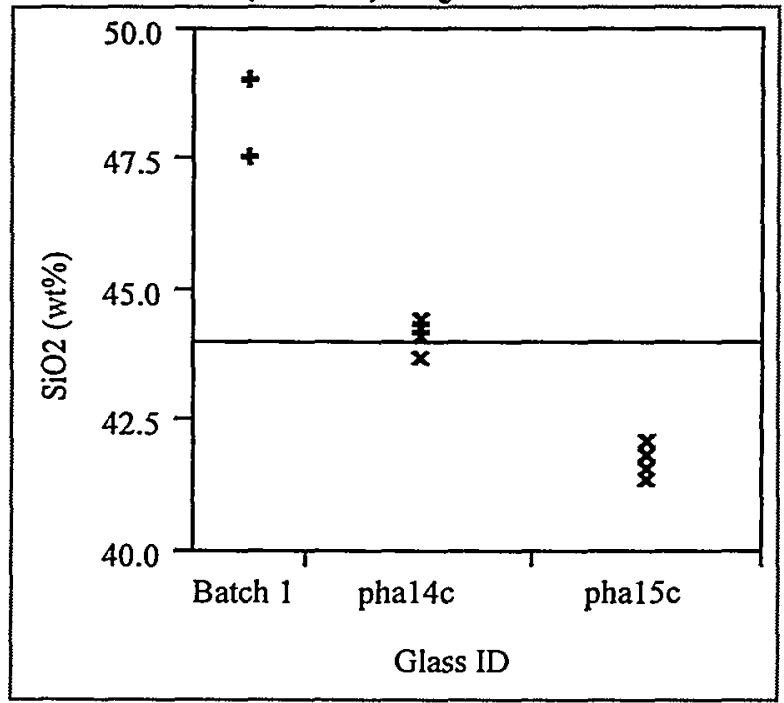

TiO2 (wt\%) By Glass ID

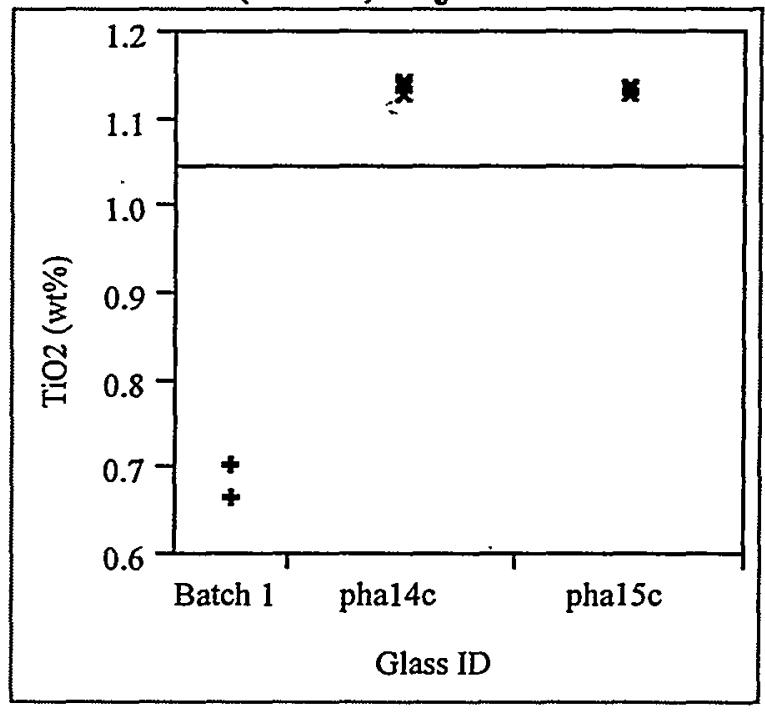

\section{U308 (wt\%) By Glass ID}

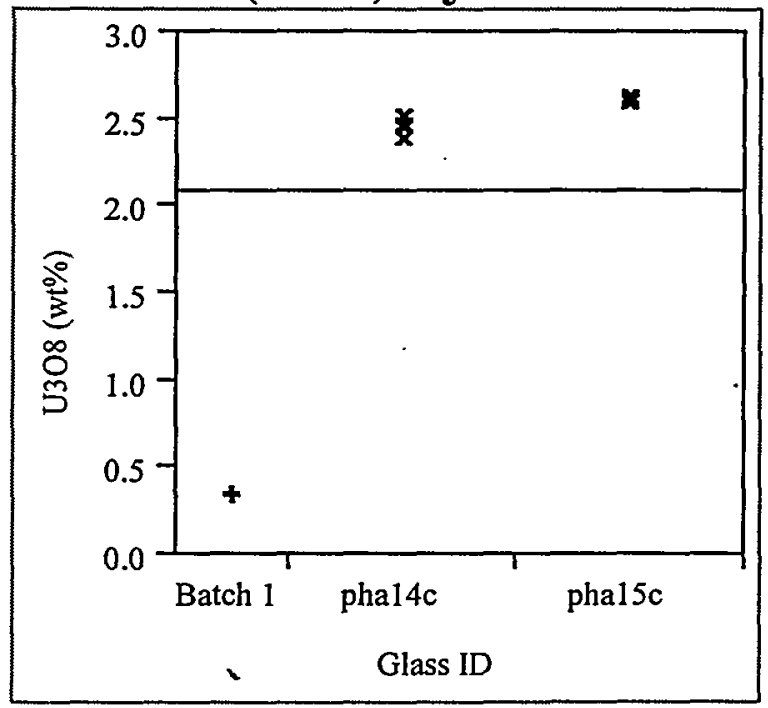


Exhibit B.1: Measurements by Glass Sample $\mathrm{ID}$ by Oxide for pha14c and pha15c

$\mathrm{ZrO2}(w \mathrm{t} \%)$ By Glass ID

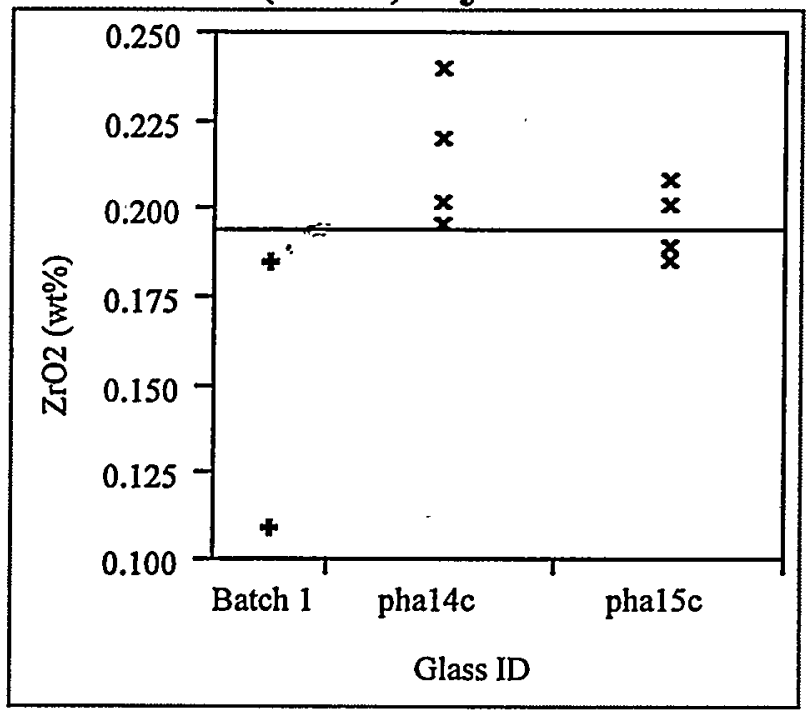

Sum of Oxides (m) By Glass ID

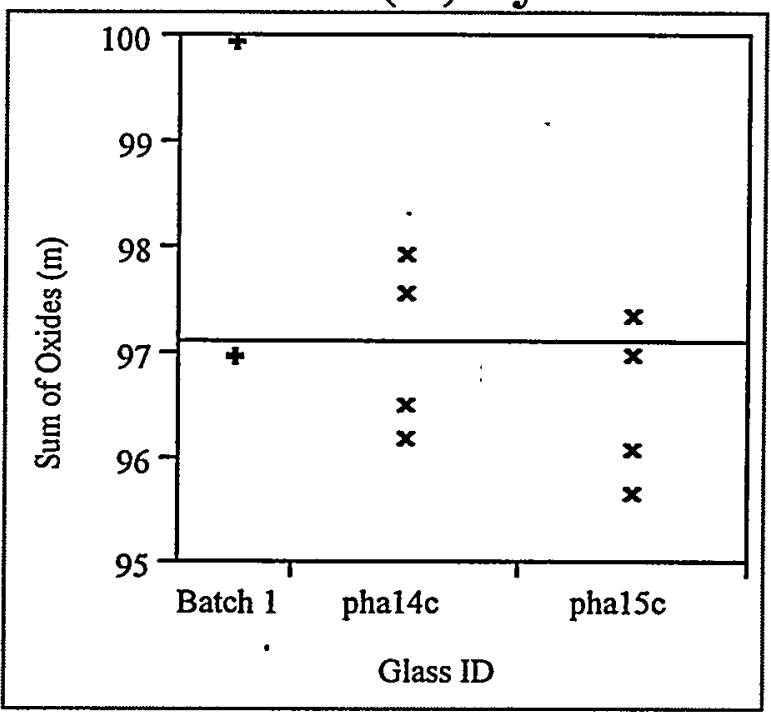


Exhibit B.2: Plots of the Leachate Concentrations by Sample ID by Element (with and without the EA and Blank samples)
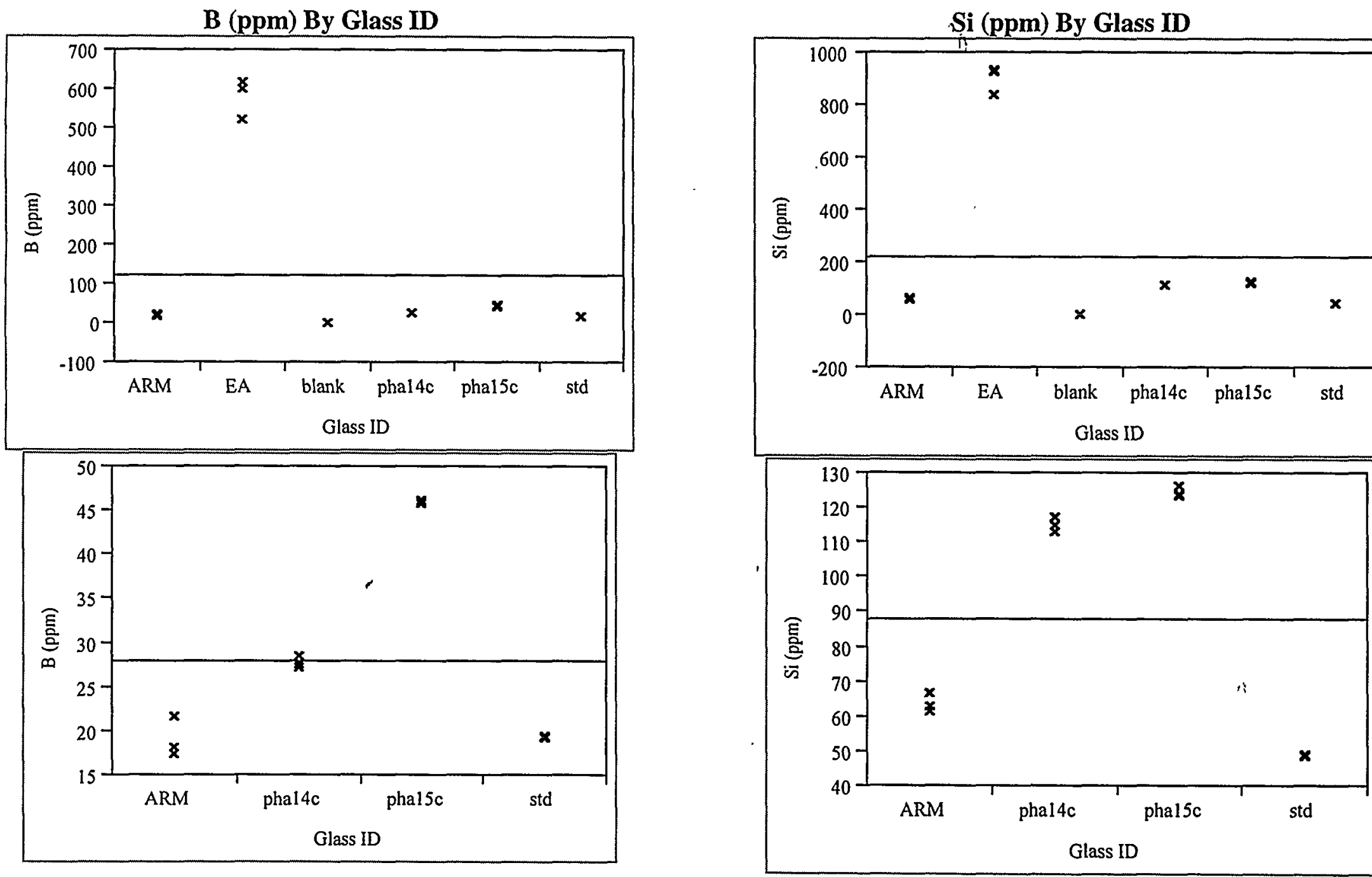

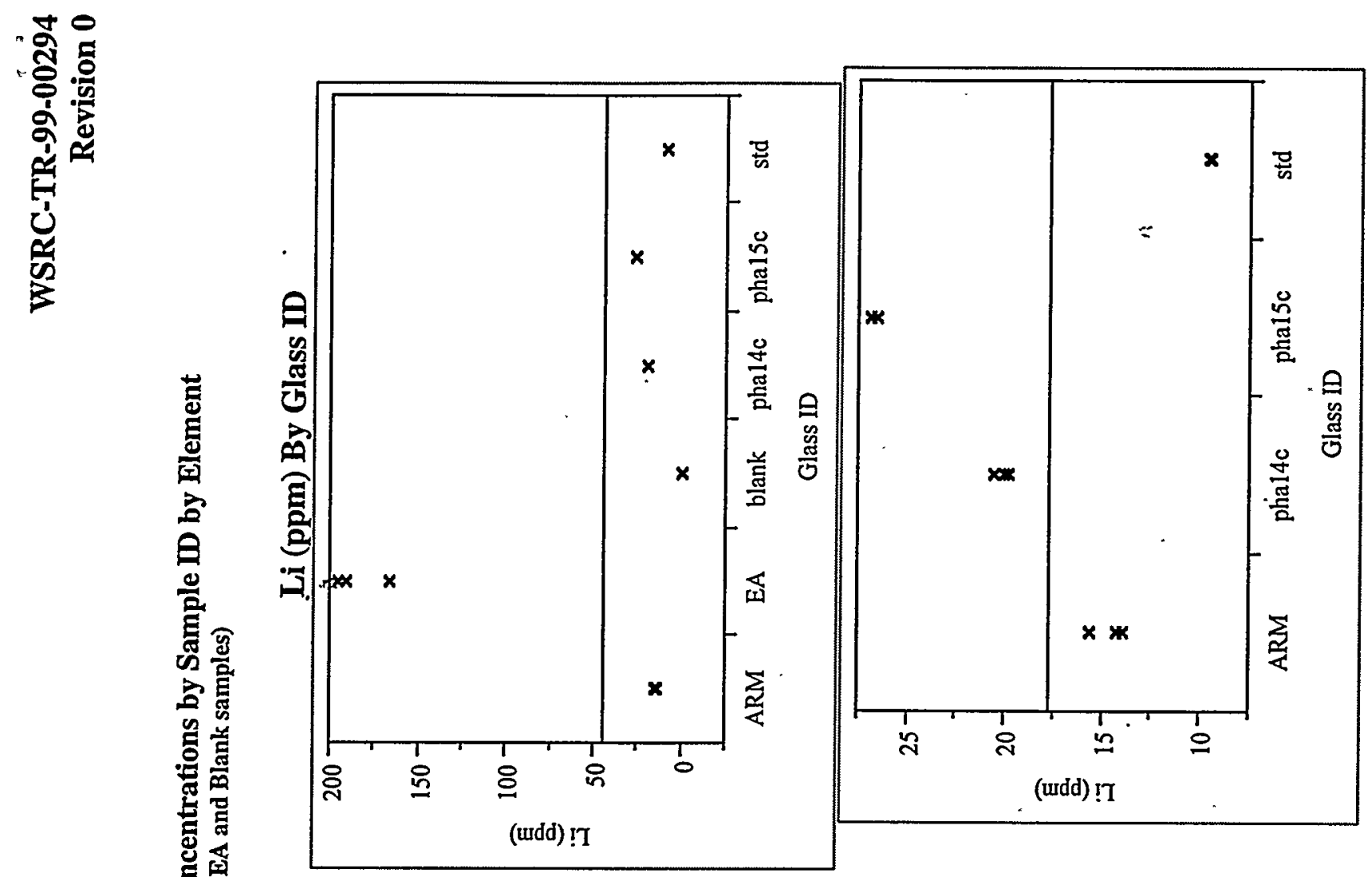


\section{Distribution}

J. L. Barnes, 704-3N

N. E. Bibler, 773-A

D. F. Bickford, 773-43A

K. G. Brown, 704-1T

J. T. Carter, 704-3N

J. J. Connelly, 773-41A

A. D. Cozzi, 77-43A

D. A. Crowley, 773-43A

T. B. Edwards, 773-42A

H. H. Elder, 704-S

S. D. Fink, 773-A

J. R. Harbour, 773-43A

E. W. Holtzscheiter, 773-A

R. A. Jacobs, 704-3N

C. M. Jantzen, 773-A

R. T. Jones, $704-3 \mathrm{~N}$

D. P. Lambert, 704-1T

L. F. Landon, 704-1T

S. L. Marra, 704-25S

D. B. Moore-Shedrow, 773-A

L. M. Papouchado, 773-A

D. K. Peeler, 773-43A

J. A. Pike, 704-3N

K. J. Rueter, 704-3N

R. F. Schumacher, 773-43A

M. E. Smith, 773-43A

T. K. Snyder, 704-1T

P. C. Suggs, 704-196N

W. L. Tamosaitis, 773-A

R. C. Tuckfield, 773-43A

R. J. Workman, 773-A

TIM (4 copies), 703-43A 